Historic, archived document

Do not assume content reflects current scientific knowledge, policies, or practices. 



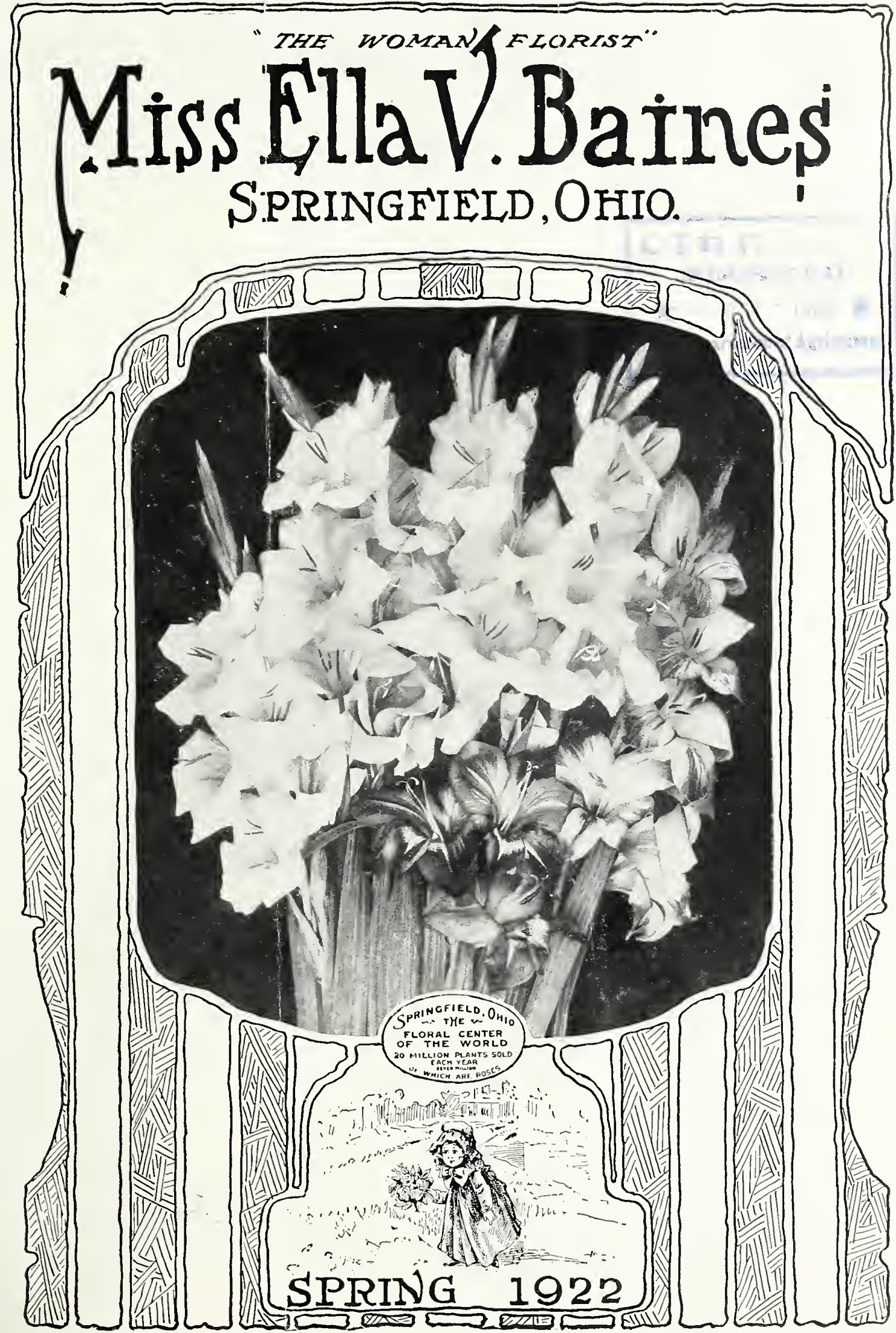




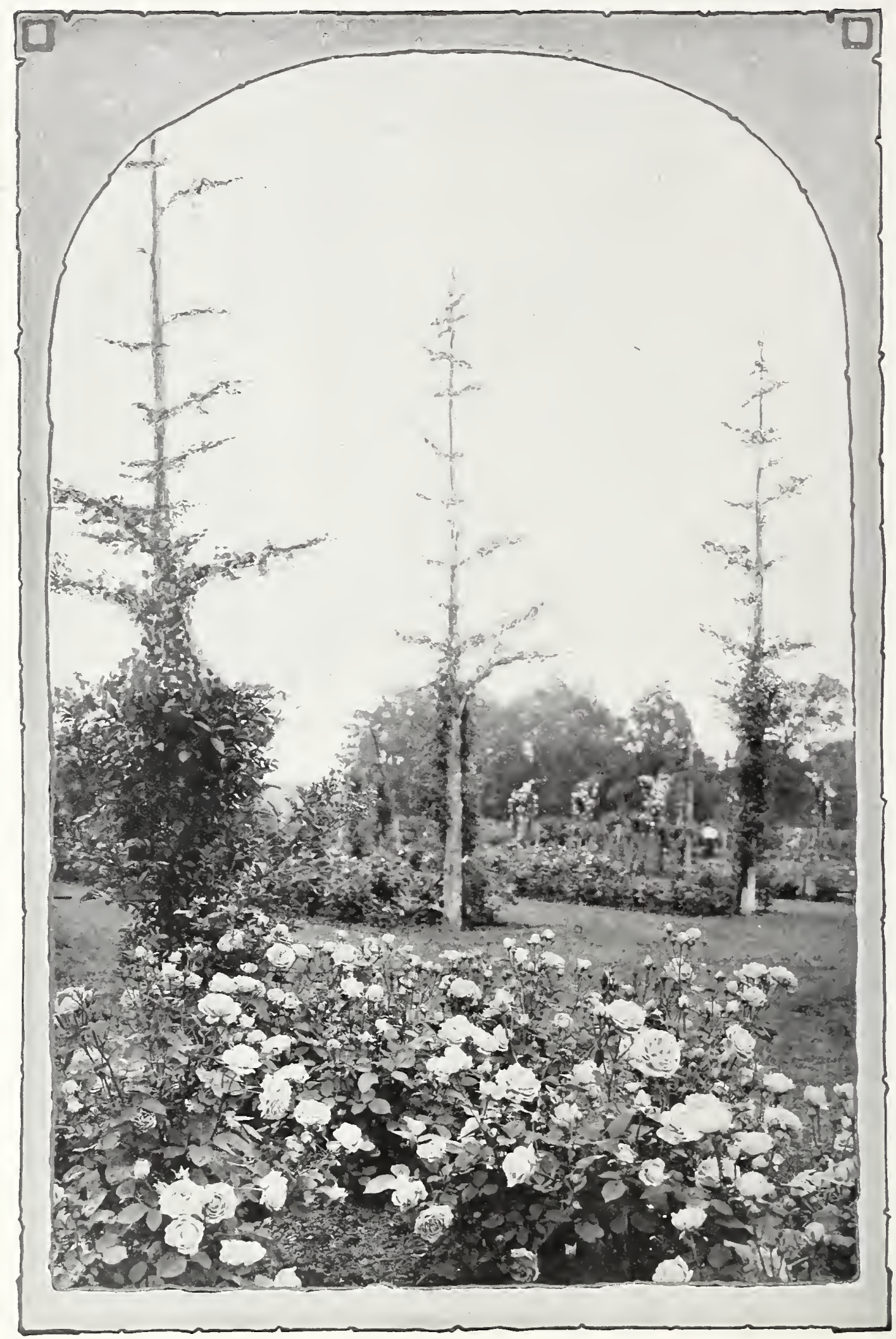




\section{SPRING \\ 1922 \\ Miss Ella V. Baines \\ The Woman Florist \\ SPRINGFIELD, OHIO}

M. $\mathrm{O}$ Cash

Ex. M. O

Stamps

Draft Total

Opened by

Date

Addressed by

Packer

o. $\mathrm{C}$

(Do not write in this space.)

Name

Street and No

Postoffice.

County

State

Express Office

How to be sent (Mail or Express)

Name of Express Co

Date of Order

R. F. D
AMOUNT ENCLOSED

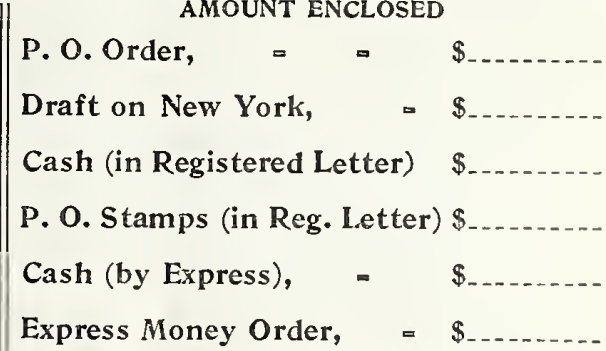

Money sent in either of the above ways is at our risk; if you send it in any other way, it is at your risk.

Please fill in the above blanks with your full name, address, etc., plainly written, and always state in what way plants are to be sent. Carry out the Catalogue price of each item and carefully add up the fuil amount. Use this sheet for ordering only, and please do not write letters on it. A careful observance of these directions will oblige us and enable us to fill your orders with greater accuracy and dispatch. Always sign your name the same. Extra order sheets supplied on request.

Should We be Sold'Out of Articles Ordered, We will Send Others Equally Good or Better.

\section{DO NOT SEND PERSONAL CHECKS}

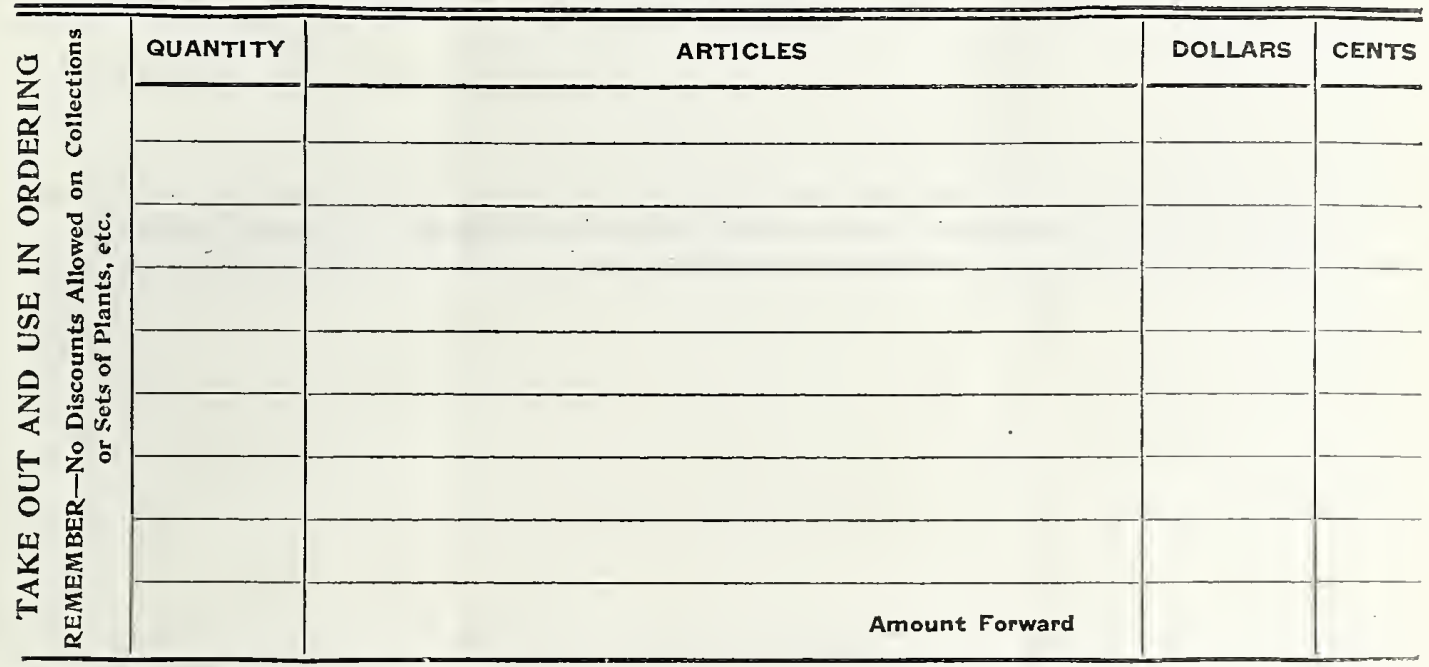

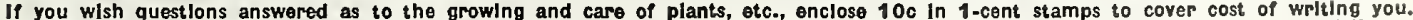

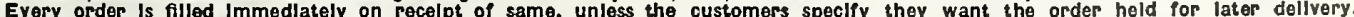

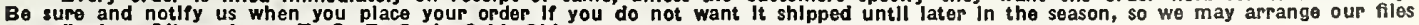
accordingly. All goods are F. O. B. Springfield, Ohlo. 


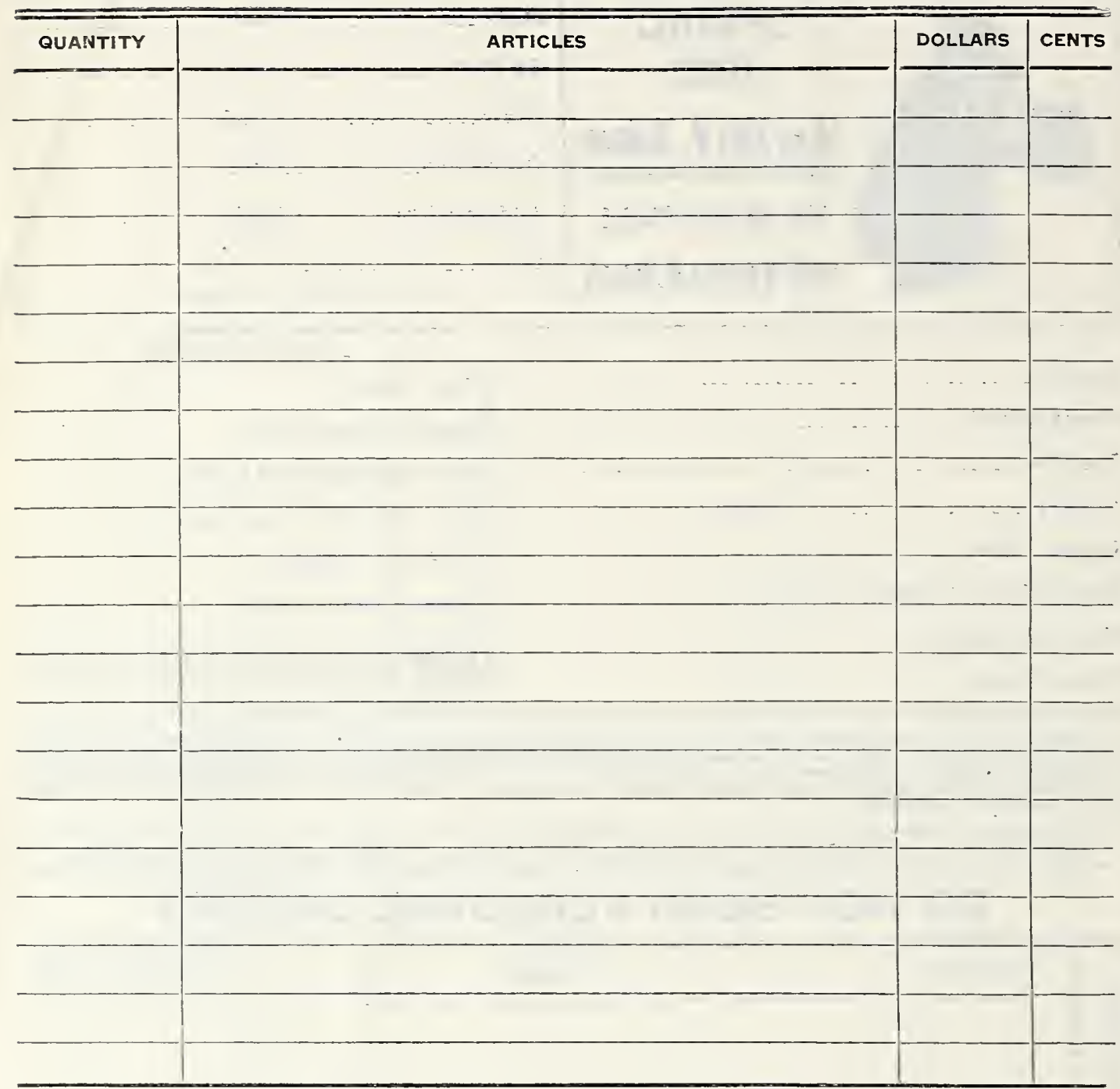

PLEASE WRITE THE ADDRESSES of a Few of Your Friends Who Buy Plants, that We May Send Them OUR CATALOG. 


\section{The Roosevelt Set of Eight Gladioli}

COSTING 76c, SENT FOR 50c.

EMPRESS OF INDIA (Velthuys)-The darkest of all. Very dark rich mahogany-red. One to delight, and one of the very best. Certificate of Merit from Haarlem and London in 1912 Each, Fe; dozen, 75e; hundred, $\$ 5.00$.

Mrs. FRANCEs KING (Groff)-Could we grow but a few varieties, Mrs. Frances King would be one of them. A most beautiful "Besnard shade" of flame-pink. Flowers of giant size on a spike growing four feet high with from eighteen to twenty flowers. Six to eight open at one time. Beautiful under artificial light. A magnificent variety. Each, 5e; dozen, 50e; hundred, \$3.50.

ROUGE TORCH - Large creamy-white flower with scarlet feather in lower petals, much like a rouge, torchlike tongue, making a striking contrast. Each, loc: dozen, \$1.00.

PANAMA (Banning)-The companion to America which has become very popular. A perfect Her- mosa-pink in color with wide open wax-like flowers; one of the best of the clear pinks; many awards. Each, 7e; dozen, 75e; hundred, \$5.00.

*PEACE (Groff) - Giant white flowers with lilac feathering in throat of two of the petals; flowers correctly placed on a tall, graceful spike. An extra fine variety. Each, 7e; dozen, 75e; hundred, \$5.00.

WAR (Groff) - Deep blood-red, shaded crimsonblack; very tall and conspicuous. The best Gladiolus of this beautiful shade of red. Try it. Each, 15e; dozen, \$1.50; hundred, \$10.00.

*WILBRINCK - Lovely flesh-pink with creamy blotch on lower petals; new and very beautiful. Said to be the earliest of all Gladioli. Each, 10e; dozen, \$1.00; hundred, \$7.00.

YELLOW HAMMER - Pure yellow; extra strong grower. Award of Merit, 1913. Each, 15c; dozen, $\$ 1.50 ;$ hund red, \$12.00.

\section{The Taft Set of Six Ever-Blooming Roses}

\section{COSTING $\$ 1.50$ FOR $\$ 1.25$. THE SET OF SIX IN 2-YEARS FOR \$2.75.}

MADAME BUTTERFLY-(New.) Is Hill's glorified sport of Ophelia. Seen and admired by thousands. All the color tones of Ophelia are intensified, making it a harmony of bright pink, apricot and gold. Ophelia ranks at the top in popularity and Madame Butterfly will surpass it. It averages more petals to the bloom; it produces more bloom to the plant because it makes more branches, every one carrying a bud. The tight buds are a lovely shade of Indian oak, yellow at the base; they are unique for corsages and for low table decorations; the opening flowers are perfect in form and texture, clear and brilliant in color and of delicious fragrance. 40 cents each.

RED RADIA NCE (H. T.)-All who know that grand Rose Radiance will welcome this red form of that great favorite. Radiance is a Rose that does well everywhere, a fine grower and free bloomer, and no prettier pink Rose grown. Red Radiance is its exact counterpart except that the color is a rich deep red. 25 each.
WHITE MAMAN COCHET (No Finer Rose Than This)-This Rose attracted our attention from the very first time we ever saw it in flower. It is of the largest size, and as you will notice, the flower is built up, or rounded, and very double. The color is a pure snow-white. Sometimes outdoors it is tinged pink, which only adds to its great beauty. No Rose surpasses it in vigorous growth and in the immense size of its buds and flowersindeed, nothing in the Tea family approaches it in size. Deliciously fragrant. 25 cents each.

RADIANCE - A brilliant rosy-carmine, displaying beautiful rich and opaline-pink tints in the open flower. 20 cents each.

PRESIDENT TAFT-It is without question the most remarkable of all pink Roses. It has a shining. intense, deep pink color possessed by no other Rose. 20 cents each.

ALEXANDER HILL GRAY - Its color is a solid deep yellow throughout. 20 cents each.

\section{The Washington Set of Five Dahlias}

\section{COSTING $\$ 1.25$, FOR $\$ 1.00$.}

SYLVIA (or Dolly)-Flowers four to six inches in diameter; of fine form and full to the cenouter petals. In freedom of bloom next to the Countess of Lonsdale. A magnificent Dahlia. Each, 25e.

FRINGED CENTURY-Intense rosv-carmine with lighter edges, fringed or cleft petals; blooms all summer; fine for cutting. Each, 25e.
FLORADORA-Deep dark, rich wine-crimson, splendid shaped flowers on long, upright wiry stems. Each, 25e.

PRINCE OF YELLOWS-One of the best canaryyellows for cutting. Each, 25c.

MATCHLESS-Deep crimson, of large size; an early and late bloomer. This we consider one of the best ten Dahlias. Very showy in the garden. Each, 25c.

\section{The McKinley Set of Four "Mums"}

\section{COSTING 80c., SENT FOR ONLY 65c.}

MARIGOLD-As a golden-yellow is unsurpassed, both as to size and color. A monster flower. Each 20e.

OCONTO-Large white blooms; on strong stems. Each, 20c.
HARVARD-Japanese reflexed, very dark crimson; extra. Each, 20c.

UNAKA-A fine incurved bloom of a pleasing shade of pink. Each, 20c. 


\section{IMPORTANT NOTICE!}

Every order is filled immediately on receipt of same, unless the customers specify they want the order held for later delivery. BE SURE AND NOTIFY US WHEN YOU PLACE YOUR ORDER IF YOU DO NOT WANT IT SHIPPED UNTIL LATER IN THE SEASON, so we may arrange our files accordingly. All express shipments are f. o. b. Springfield, Ohio.

\section{HOW TO GET YOUR PLANTS FREE}

Make up a Club Order among your friends and neighbors and thus get your own plants free. Everyone has an acquaintance who, if aware of the fact that you were sending for lowers, would join you for your trouble in sending their order.

We give you the following liberal discounts. It will ba well worth your while to interest your friends. Try it.

For every dollar you send us to go by mail select 10 cents extra for your trouble. To illustrate, say you send us $\$ 3.00$, select 30 cents extra for your trouble and so on.

\section{EXPRESS CLUBBING RATES}

For every dollar you send us to go by express select 20 cents extra for your trouble. To illustrate, say you send us an order for $\$ 6.00$, select $\$ 1.20$ extra for your trouble, or a total of $\$ 7.20$.

THIS DISCOUNT DOES NOT APPLY TO ANY SPECIAL OFFERS OR COLLECTIONS. IT ONLY APPLIES TO SINGLE PLANTS OR BULBS.

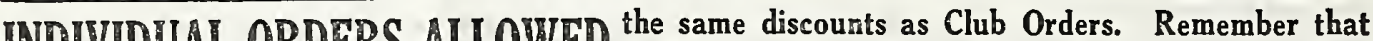
INDIVIDUAL ORDERS ALLOWED the premiums or discounts must be selected and sent with your order. We cannot send them at separate times unless you add 10 cents to each dollar for postage.

\section{WHAT OTHERS SAY}

Johnston, S. Car.

Dear Miss Baines:-

I lave been ordering flowers for nineteen years, but liave never received a package in such perfect condition as the Begonias are, not even pruised. The Geraniums look as fresh as if I liad iust taken them from a pot. I am glad to tell wou this for I feel that too often we withhold a word of encouragement that would malie easier life's burdens.

MRS. W. J. H.

Hartford, Káan.

Wlla V. Baines, Springfield, Ohio.

Dear Madami:-I never have had finer Roses come to me than the ones you sent this spring. Tliey were so well packed and fresh when received. All are doing well so far. Thank you. Very truly yours,

MRS. R. D. C.

Sta. B, Rt. 1, Columbus, Ohio.

Miss Ella V. Raines.

The Gem Collection of $R$ oses received from you in March is a marvel. The three Foses each bear a large bud now, and their strong growth is surely gratifying. In size they compare favorably with Roses eosting 25,30 and 35 cents.

w. B.

New Orleans, La.

Miss Balnes:-

I received my plants that you sent me yesterday and must way I was more than thankful to The plants are just grand. I don't know you. The plants are just grand. I don't know how to thank sou, you sent me more than I ex-
pected. Do I owe you any more noney? Write and let me know, and I will send lt to you. You wlll by so doing oblige me.

L. C.

Fort Worth, Texas.

Miss Ella V. Baines, Springfield, ohlo.

Dear Madam-I deslre to express to yon my appreclation of the splendid quallty of the "Llly of the Valley" you sent me. Thanks to the splendid packing. The pips arrived in splendld condition and were planted at once, and after onIy six weeks they are a mass of beantiful blooms, every pip sending up from two to five splkes of beautiful blossoms, and are the admiration of all our visitors.

I feel repaid many times over for the small trouble and expense incurred in this case and will remember where to order again when I wish such satisfactory results.

Again thanking you, I an

$$
\text { Yours very truly, }
$$

$$
\text { T. S. H. }
$$

Ella V. Baines:-

Rison, Ark.

Received rour four little Roses and they are growing nicely, also the four "Mums." Other Hoses of rours of last vear are loing splendid, and the Killarney and Bessie Brown I cot from you a few years ago are the most beantiful things in this country. Your little Roses have splendid roots and I have not had one to die.

B. $\mathbf{B}$.

Fresnillo, Zac., Mexleo.

Miss Ella V. Baines, Springfield, Ohio.

Iy Dear Miss Baines:-I want to tell you about the order of flowers and bulbs you sent to me in Decenber. I have never received plants packed so beautifully as those were, they came through in perfect condlilon and ail lid started new lenves. The Lilacs had bly, fat leaf buds on them, and the nlce part of it is, they didn't lry off when I put them in the ground, but have just kept on growing. The Little "Baby" Roses are ln full leaf now. I surely appreclate your care in packlng them for lt. ls such a long trlp I seldom receive plants in good shape even from San Antonlo, Texas. They came through in extremely short time for a package; they were only ten days. Thanklng you agaln, I am, Very alncerely, IRS. JóHN S. $\mathbf{B}$.

\section{IF YOU WISH ANY QUESTIONS ANSWERED}

As to the Growing and Care of Plants, Etc., Enclose 10 Cents in One-Cent Stamps to Cover the Cost of Writing You. 


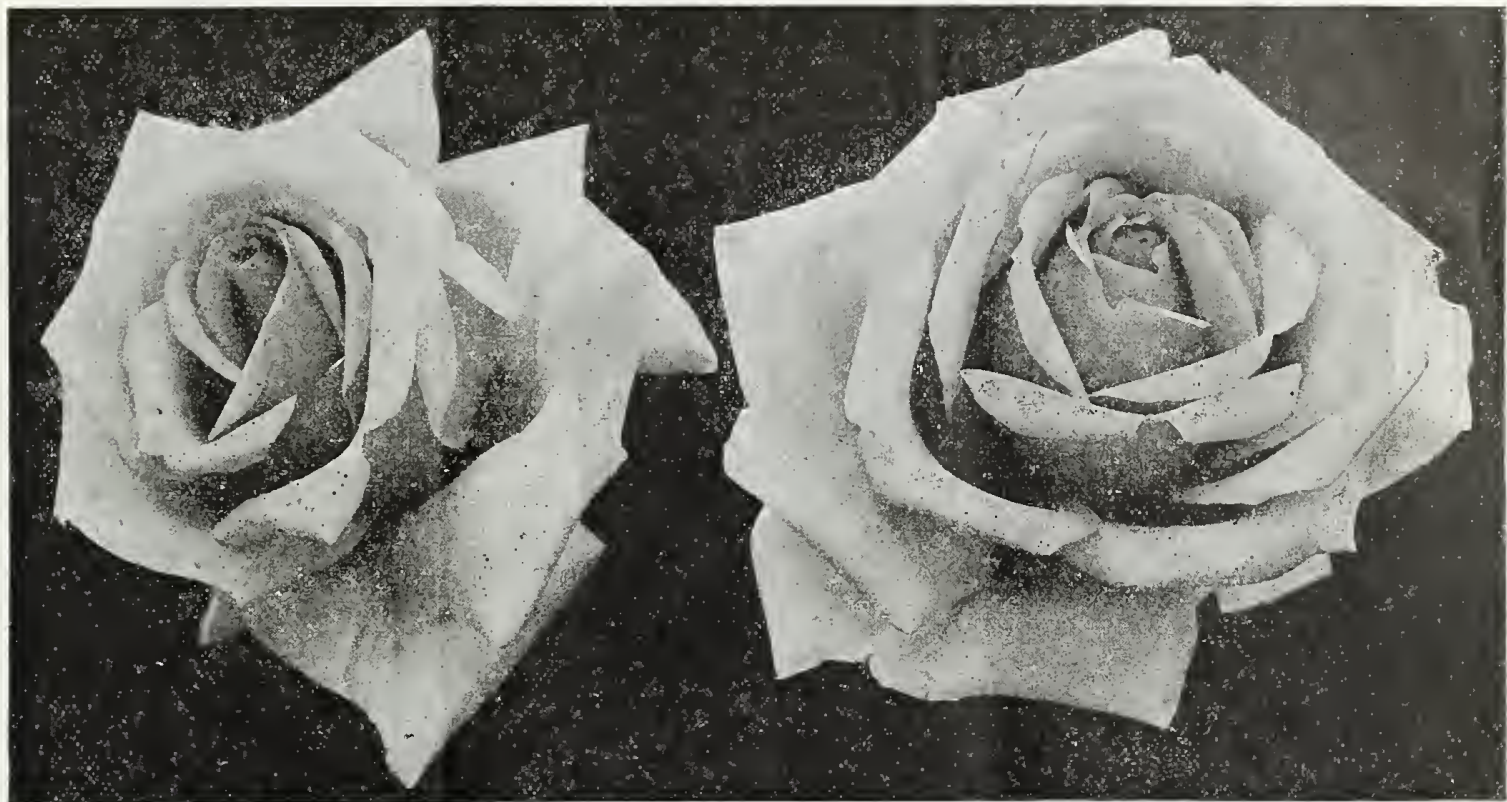

Columbia.

\section{THE CREAM OF THE NEW ROSES}

We here offer what is good in the new Tea and Hybrid Tea Roses. To have what is good you must try these Roses. . They "are the best that England, France, Ireland, Italy, Holland and America can produce.

\section{Price, 25 Cents Each, Except Where Noted. Two-year Plants 60 Cents Except Where Noted.}

CHARLES K. DOUGLAS (H. T.)-Bud large, longpointed: flower large, full double, sweet fragrance: color, intense flaming scarlet, flushed, bright velvety crimson. Foliage, dark green; disease resistant, vigorous, upright grower, produces an abundance of blooms from June to October. 50 cents each. No two-year to offer.

ColumbIA (H. T.)-This is a new American Rose. grown by the veteran rosarian $\mathbf{E}$. G. Hill. It is a very vigorous grower of a true pink shade, deepening as it opens to glowing pink. A peculiarity of this variety is that the shades all become more intense until the full maturity of the open flower is reached, and this color is enduring.

COLONEL OSWALD FITZGERALD (H. T.)-A brilliant Rose. Its blood-red velvety crimson beautifully finished blooms are produced in great profusion on erect stems; branching pure tea perfume We have no hesitation whatsoever in describing this variety as excellent. Named in remembrance of Colonel Oswald Fitzgerald-a lover of roses-who perished with his chief, Lord Kitchener. 50 cents each. No two-year to offer

COH NELIA-Ophelia X. Mrs. Aaron Ward. A splendid cross between these two well known Roses. Flowers are medium to large size and very double. The bud is a beautiful salmon-pink. In the half expanded and full flowers the outer petals are light flesh, with the center a bright Malmaison pink; base of petals bright orange. A strong, vigorous grower with good stem and foliage.

IRIMSON QUEEN (H. T.)-A very strong, upright grower, flower large and full. Color a rich bright velvety crimson. A grand garden Rose, as it is always in bloom.
CRUSADER-(New), A big, strong growing variety, robust and rugged in every characteristic. The growth is heavy and the flower stem strong and heavy. It is free flowering and the blooms arc big and double and in color a rich velvety crimson. A free flowering red Rose that is a wonder. 40 cents. No two-year to offer.

EDFL (H, T, -Type, Florence Forrester; bud, very large; flower, very large, double, well built, state$1 y$, opens well in all weather; sweet fragrance. Color, white, with the faintest ivory shading toward base, passing to pure white. Foliage, bold and distinct; very vigorous grower; free bloomer 50 cents ench. No two-year to offer.

FLORENCE FORIRSTER (H. T.) - Clear snowwhite with a lemon tinge; as the flowers age they become a pure white; the blooms are even larger than Paul Neyron. Its habit is absolutely perfect. and the freedom with which it flowers is marvelous. We consider this Rose the grandest of all whites for bedding. For size and substance has no equal among Hybrid Teas. Is very sweetly perfumed. Gold medal, National Rose Society.

FRANCIS SCOTT KEY (H. T.)-It is very fitting that such a fine new Rose should be honored with the name of the author of the "Star Spangled Banner," and also that it should hail from Baltimore, one of whose forts was being assailed"when the inspiration came to the author to write our national anthem. The flowers are from large to very large, with sixty or more petals opening to a high center. The color is a magniflcent deep red rose. Wherever it has been staged this Rose has swept all competitors from the boards and secured every prize it has entered for. Grand for the garden. 


\section{THE CREAM OF THE NEW ROSES-Continued}

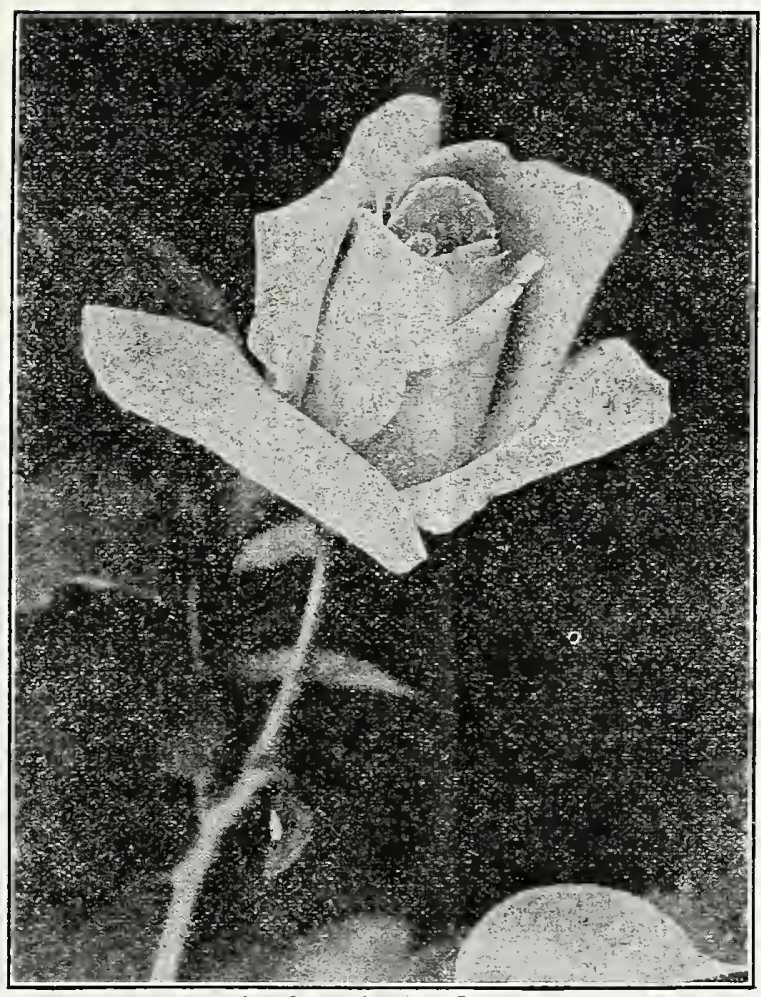

Madame Butterify.

MADAME BUT'ERFLY-(New.) Is Hill's glorified sport of Ophelia Seen and admired by thousands. All the color tones of Ophelia are intensified, making it a harmony of bright pink, apricot and gold. Ophelia ranks at the top in popularity and Mad. ame Butterfly will surpass it. It averages more petals to the bloom; it produces more bloom to the plant because it makes more branches, everyone carrying a bud. The tight buds are a lovely shade of Indian oak, yellow at the base; they are unique for corsages and for low table decorations; the opening flowers are perfect in form and texcure, clear and brilliant in color and of delicious fragrance. 40 cents. Two-year, $\$ 1.00$ each.

MISS WILMOT (H. T.) - The most reflned and charming Fiose ever raised. There is an appealing sweetness about this most distinct variety that will please lovers of Roses all the world over. The color is practically a uniform soft sulphurycream, with the faintest flush towards the edges. In shape and form this Rose is a model of perfection, every flower comes perfect and produced with a freedom that is marvelous. A wonderful garden Rose. Gold medal, N. R. S. 40 cents. No two-year to offer.

MR. P. L. BAUDET (H. T.)-Color carmine-rose flecked with salmon-yellow, center darker. Flowers large and full, vigorous in growth, continuous in bloom. A unique two-tone Rose.

MIRS. BRYCE ALLAN (H. T.) - Strong Moss-rose perfume, Color carmine-rose. Flowers globular in form, very erect stems, deep green foliage.

MRS. CHARLES BELL (Pierson, 1918)-This new Rose will appeal to those who grow Roses out of doors. It may be described as a shell-pink Radiance, and is a sport of that well known Rose It has no characteristics which make it distinct from Radiance except that it is shell-pink. Mrs. Chas. Bell Red Radiance and Radiance offer a range of color that will be welcome. No finer garden Roses for America than these three.

MRS. CHA RLES RUSSELY ( $H$. T.)-This wonderful new American Rose has taken the country by storm. No other forcing Rose except "American Beauty" can compete with it when it comes to counting points. Stems three feet long stiff and surmounted by grand rosy-pink blooms of the largest size and build. 40c. No two-year to offer.
MRS. CAMPBELL HALL (Tea)-Delicate creamybuff, edged or suffused rosy-carmine. The center of the bloom is warm cerise coral-fawn. Very deliciously fragrant. Awarded gold medal, N, R. S.

MRS. CURNOCK SAIVDAY ( $H$. T.) - A vigoroưs grower, with bright green foliage The well shaped blooms carried erect on long stems, are sweetly scented. The color is a pleasing shade of pale blush-pink, a good garden rose in commerce. 50 cents each. No two-year to ofier.

MRS. HENRY WINNETT (H. T.)-This is a seedling raised by John $H$. Dunlap, of Canada, and has the distinction of being the first seedling Rose of Canadian origin that has been offered in commerce. In color it is a bright shade of crimson, not so dark as Hadley, and not so light as Richmond. It is a color that pleases the retail storeman and his patrons. The finest of all the red or crimson varieties. The buds are long and well formed. A superb red Ross. 40 cents. No two-year to offer.

MRS. HENRY MORSE (H. T.)-Bud very large, long pointed, flower very large, high center, double, fragrant, color flesh-cream ground with a sheell of bright rose, deeply impregnated and washed vermilion with clear vermilion veinings on petals; very vigorous grower, bearing an abundance of bloom. 50 cents each. No two-year to ofrer.

MIRS. JOHN COOK-White, suffused with delicate pink, describes the color of this strong-growing big-llowered daughter of Ophelia. The color varies with the season, the flush of pink being more pronounced during cool weather, while the Rose is almost white during the long days of bright sunshine. In bud it is nicely formed, the mature flower opening cup-shaped but expanding fully to a large and finely-formed bloom. It is bigger and better in summer than White Killarney and, with its delicate pink in dark weather is a very charming color. 50e. No two-year to offer. MIRS. FIACIELLAR ( $H$. T.)-The glorious blooms make this an imposing Rose. A deep citron or delicate pure canary color. As the large blooms gracefully expand the guard petals charmingly reflex and become pearly primrose-white of great decorative beauty. Award of merit (unanimous) R. H. S., London.

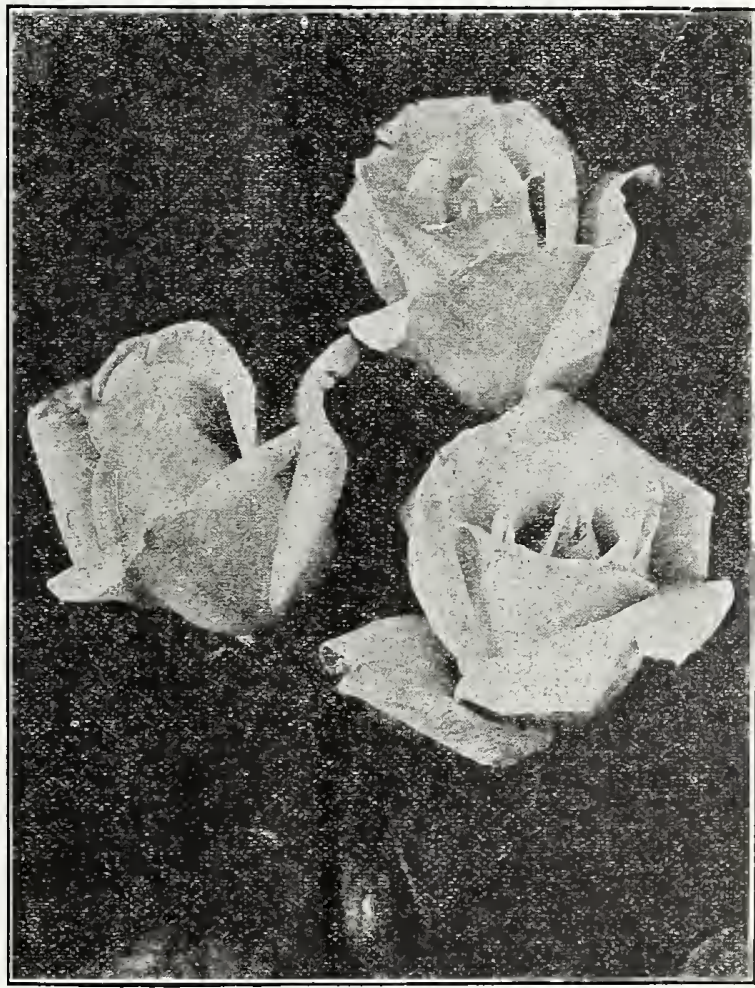

Ophelia.

(See description on page 6.) 


\section{THE CREAM OF THE NEW ROSES-Concluded}

NATIONAL, EMIBLEIT (H. T.)-Dark crimson, of perfect shape, habit and inflorescence; as a bedding, massing and cutting Rose it is unique. Buds long and pointed, opening to large, full, handsome flowers of great beauty, flowering freely and continuously.

OPHFiLA-Salmon-flesh shaded with rose, large, and of perfect shape; of excellent habit; the fowers standing up well on long, stiff stems and produced in great profusion. Excellent for forcing and a fine decorative variety. Growth vigorous. Certainly a glorious Rose. Be sure to have "Ophelia" fixed in your memory.

DIGRI-(New.) In color, a beautiful shade of bright rose-pink. The bud, which opens periectly, is long and of ideal folm. Pilglim is a Rose of good substance and petalage, and at any stage of development is perfect in color and form of flower. Its pronounced tea fragrance will attract all Rose lovers. It is prolific and highly productive of îrst quality blooms. The stems are straight and strong. It is the pink Rose to grow. 40 cents. No two-gear to ofEer.

PREMIER-This is the long-looked for deep Rose for the garden; a beauty, and one you will be pleased with. It is a very free blooner, almost smothering the plant. The color is bright and smothering the plant. The colol is bright and
attractive. The growth is all that is to be de- sired, and altogether a wonderful Rose. 40 cents. No two-year to offer.

RED RADIANCE (H. T.) -All who know that grand Pose Radiance will welcome this red form of that great favorite. Radiance is a Rose that does well everywhere; a fine grower and free bloomer, and no prettier pink Rose grown. Red Radiance is its exact counterpart except that the color is a rich deep red.

RICHMOND-Pure rich scarlet; very free and continuous flowering; splendid forcer.

ROSE MARIE (H. T.)-This is a grand Rose of the very highest merit. A rich red that has come-to stay. Might best be described as a bright watermelon-red. Very desirable.

'TMP'PESARY (H. T.)-In color stands between Lady Hillingdon and Melody, showing an attractive shade of soft golden-yellow in the bud and half developed flower. Its fleedom of flowering and its habit of glowth will make it one of the most desirable Roses of its color.

W. C. GAUNT (H. T.)-Of medium size, with pointed buds, with naturally reflexed guard petals of brilliant velvet vermilion, tipped scarlet. Stems rigid. habit branching, large oval beech-green foliage. Rich tea fragrance; very rich in color.

\section{The "Excelsior" List of Ever-Blooming Roses}

\section{New and Choice for Outdoor Planting or House Culture}

I'rice, 20 cents each; any thrce of yow own selcetion for so cents. Two-year plants, 40 cents each; three for $\$ 1.00$.

For general planting, more especially in open ground, this class excels all other.s. One-year-old plants, such as we send by mail, bloom the first and each succeeding year from early sping until severe frosts. Two-year-old plants, of course, yield a greater profusion of flowers, owing to their size. The flowers are noted for their exquisite coloring and delightful fragrance; hardy everywhere in open ground with protection of litter, leaves, evergreen boughs or similar materials. Plant liberally of one-year-old Roses: the harvest of bloom they give the first year compensates for the trifling outlay. Anyone can succeed with them.

\section{"EXCELSIOR" LIST OF ROSES OF SPECIAL MERIT}

\section{In Ordering Say "From 'Excelsior' List"}

ALEXANDER HILL GRAX - Largest pure yellow; extra.

ARCHDUKE CHARHAS-Deep carmine, reverse silvel'y-pink.

BEAUTY OF STAPLEFOEB-Bright, rich rosycrimson.

BLU MENSCHMIDT- Rich lemon-yellow, of t e $\mathrm{n}$ tinged pink.

BUIBNK-Bright pink; a grand bedder; always in bloom.

CTHEIRIN MIERMTT-Color a clear rosy-pink; large and fine.

CHAMTION OF TER WORHD-Rich, deep, rosypink; extra fine.

CHRISSE MACRERLAR - Crimson-calmine a $\mathrm{n} d$ orangey-pink.

CLOTHIIDH SOUPER-Everybody's favorite light pink Rose.

COLONEE IR. S. WILLIAMSON-Satiny-white, with deep blush center.

COINELA COOK - The old favorite white Rose; none better.

COUNTESS OF GOSFORD-Clear salmon-pink and saffron-yellow.

DEAN HOI.L-light carmine, shaded salmon; extra fine.

DEVONIENSFS - Magnolia fragrance; a delicate creamy-white.

DOUILE VIITI KILEARNAY-A pure white sport from White Killarney. A great forcing Rose.
DECERSS DE BRABANT-Bright salmon-pink; an old favorite.

DUCHESS OF ALBANY (Red La France)-A superb Rose.

DECHESS OF WELLFNG'ON-Intense saffron-yellow; stained red.

ECAILATE-The finest red bedding Rose to date.

GDVVAIT IIALEY-The finest of all dark crimson froses.

EIIDESS EUGENHE-Deep, rich pinli; very double; hal $d y^{*}$.

NTGENE E. MARLIT-Fich bright carmine with scarlet tones.

FLORENCE PEMBERTON - Creamy-white, flushed and shaded.

IN. R. P'TRR-Creamy-buff, reverse delicate pink extra fine.

GENRRAL MeARTHCR-A superb, deep, rich red Rose; new.

GNERAF, SUPERIOR ARNOLD JANSEEN-GIOWing carmine. Extra.

GENERA TARTAS - Color rich, deep rose; very fine.

GOLDEN GATE - White; most beautifully tinged pink.

GRUS $\Lambda \mathbf{N}$ TEPI.ITZ-Brightest red of all Roses. Extra.

HERMOSA - Beautifui bright pink flowers; old favolite.

JOVKHEQR J. L. MOCK-A glorious pink Rose. 


\section{The "Excelsior List of Ever-Blooming Roses-Concluded}

KILLAFNEY-Clear rich deep shell-pink; a great beauty.

LA FRANCE-This is claimed by many to be the queen of all the Roses; bright silvery-pink.

LA DERROIT-Shell-pink, shading to rose; elegant. CADY ASHTOWN - Deep rose, shading to silverpink.

IADY BATTERSEA-Long pointed buds of richest red; elegant.

LADY HILLINGDON-Deep golden-yellow; superb.

LADY URSULA - Flesh-pink; large, full and perfectly formed.

LA TOSCA-Soft pink, tinted rosy-white; extra.

LAURENT CARLE-Deep rosy-carmine; extra finc.

LoULS PIILLIDL-Bright red; very free bloomer.

MABEL DREW-Deep eream and canary-yellow.

MADAME AIBEY, CHATENEY - Rosy-pinl, with

lighter shadings.

MADAME CAROLINE TESTOU'-Bright pink.

MADAMG CONSTAN'T SOUPER'-Deep yellow.

HADA IE DE VATHE (Creole Beauty) A fine red.

MADABE JENXY GILEMOT-Saffron-yellow, opening pale yellow.

MABAMU JULES GIROLEZ-Rose and satiny-pink;

MADAME LOMBARD - Rosy-red, with silvery reflex; extra fine.

MADAME PAUL EULER-The famous pink Prima Donna Rose.

IADADE SEGOND WEBER - A beautiful grand deep pink.

MADEMOISELLE FRANZISCA HRTGLIE-D e ep coppery yellow.

HADGMOSELLE HELENE CAMHIER- Coppery yellow; deep center.

UADISON-Pure white, exquisite.

MARIE GUILEO' The old standby for a pure White Rose. HOUTT-Straw-yellow flushed with crimson.

IETEOR - A grand rich dark erimson: superine.

UISS CYNTHA FORDE-Deep brilliant rose-pint.
MRS. A ARON WARD-Golden-orange, distinct and

beautiful.

MIES. A. R. WVADELL-Clear deep salmon.

BHIS. BENJAHIN R. CANT-Deep, dark carmine extra.

MIS. GRORGE SIF WVER-Bright peach-pink; superb.

MY IHAYLAND-Clear, glowing pink; extra

PEIRE DES MARDINS-Clear golden-yellow; very rich.

PERL VON GODESBURG-Pure white, yellow center.

IRED HATETE DAY-Glowing crimson-scarlet.

RHEA RERD-Richest decp crimson; fine for garden.

SNOWELAKE-Snow-white; most profuse bloomer of all Roses.

SormIRER-Pure white, linged delieate pink hardy.

SOUV. DE LA MAHIRASON-Creamy-flesh, rose center.

SOUVENTR DE RTES. CARNOT-Grand Rose of the largest size; color delicate fawn or salmon; fine.

SOUV, DE PJFER NoTTHA-Orange-yellow, bordered carmine.

SUNBURST-The magnificent giant yellow Rose.

TIE AUEDr-Beautiful, large, pure white flowers extra.

VISCOUNTES FOKSTONE - Pure white, faintly tinted fawn.

WBLLESLEY-Sclf-pink, very bright in color.

WHITH: TKLIAENY - Pure snow-white; extra.

WHITE IA FIRANCE-Pure, white with shadings of fawn.

WIITE: MALIIASON-Pure white, shaded lemonyellow.

IVIVNIS DAVIS-A most beautifuI Rose. Apricotpink with tints of the Aurora Borealis. Superb.

YVONNE VACHEFOT-Porcelain-white, retouched with red.

\section{Climbing Tea and Noisette Roses}

This class includes some of our most beautiful and valuable Roses. They are unusually free and continuous bloomers, producing flowers of rare and striking beauty. As they are all climbers, they should be placed near porches, pillars or trellises, where they have support. They are hardy in the south.

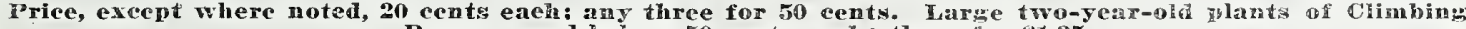
Roses named below, 50 cents each; three for $\$ 1.25$. CLIMBING CLOTHILDE sOUPEIT- Ivory-white
center deep silvery-rose.

CLIMBIN DEVONIANSIS-The Climbing Magnolia Rose; blush-white.

CLIMBING ETOILE DE FRANCE-Dazzling velvety crimson.

CHIIING GRUSS AN TEPLITZ - Deepest bright scarlet.

CLIMBING HELEN GOULD-Richest watermelonred. Very free. Grand.

CLIMBING KAISERIN $A$ UGUSTA VICTORIA OF IIRS. ROBERT PEARY-Ivory-white; elcgant.

CIIMBING KILLARNEY-Long pointed buds of clear Killarney-pink.

CLIMBING MARIE TUILLOT-A grand pure white Rose of great merit.

CLIMBNG MIE. C. TESTOUT-Clear shell-pink, edged silvery-rose. 'Two-year, 6i) cents each.

CLIMBING MLLE. C. BRUNNER - Rosy-pink on creamy-white ground.

CLIMBIN G ME'TOR-The acme of all red climbing Roses.

CLIMBHNG PAPA GONTIER-Bright coral-red; fine CLIMHIN F PERLE DES JARDINS-Golden-yellow. CLIMBING SOUV. DE LA MALMAISON - Creamyflesh: peach-pink center.

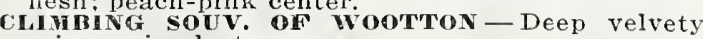
crimson in clusters.
CLIMAING WHTTE PATIAN COCHER-This is a climbing form of White Cochet. Same flowers, same color; nothing beats it.

CLOTI OF GOLD (Chromatella)-A clear goldenyellow.

FOR'TUNG'S DOUBL KHELW - Knowis in California as the San Rafael Rose.

GAINBOROUrH - White, delicately tinted flesh; extra.

JAHES SPRUNT-Deep velvety erimson; very double.

LAMARREE-Pure white; very double; an old standby.

MARECFAL, NEL-Magnificent golden-yellow. We have extra strong plants of Marechal Niel at $\$ 1.00$ and $\$ 1.50$ cach.

IILLAR OF GOLD (E. Veyrat IIermanos)-Apricot and golden-yellow.

REINE MATE IFWRHETE-Pure cherry-red sweet-scented

REVE GOE (Gollen Chain or Chimbing Satrano) Orange-yellow.

SOLFATARE-Clear sulphur-yellow; large, full, double.

พ. A. 耳ICIARDSON-Orange-yellow; centcr coppery-yellow,

WHIT! BOUGBRE-Lovely pure white.

\section{New Varieties of Tender Climbing Roses}

CLIMBING LADY ASHTOWN-Almost hardy; produces a large crop of large soft rose-colored
flowers; a beauty. 35 cents cach. Two-year 60 flowers; a

CIIMBING HAMAN COCHET-This is a climbing form of that famous Rose Maman Cochet (see the description in "Famous Rose Collection"). This is the same except a climber. Superb. 35 ecmts. 'Two-ycar, fio cents each.

CLIBIBAG OPIIELIA-A climbing form of Ophelia No better Rose orown than this; a beautiful pink. 35 cents. Two-yenr, (0) cents each. 


\section{Polyantha, or Baby Roses}

A class of miniature Roses derived from the Climbing Polyantha. They are of dwarf habit and bloom so freely as to cover the entire plant with bloom all through summer and fall. The plants are splendid for bedding, or as edgings for borders they are hardy. Let us tell you something about these miniature Roses. While Europe has appreciated these Roses for years, America is just beginning to wake up to the fact that they have come to stay. They are useful either pot grown or for bedding purposes or for hedge effect. 20 cents each; six for $\$ 1.00$; two-year plants, 50 cents each; three for $\$ 1.25$.

ANNA MULLER-The pink Baby Rambler; always in bloom.

BABY RAHBLER-Completely hides itself all summer; bright red.

CATHERINE ZEIMET-The White Baby Rambler;

ELLEN Poulson-Dark brilliant pink; fragrant;

ERNA TESCHENDORFF - Deep crimson flushed with carmine; very dark

JESSIE-Bright cherry-crimson. Superb.

LE POCHEA U-Dark red in large clusters.

MADEMOISELLE CECILE BRU NER-This is the popular Baby Pink Rose. It is also known as Sweetheart and Mignon. In the past year or two this Rose has fairly jumped into popularity. It always was a popular outdoor Rose on the Pacific Coast, but recently even in the effete East and everywhere in America they are planting it sim. ply by thousands for cut flowers. It has become quite the rage. It makes a handsome miniature Rose, coming in sprays of three to five buds and combined in beautiful effect with so many other flowers in all kinds of floral work. It is a very prolific bloomer and if carefully protected in the winter should be a money-maker, both outdoors and under glass. The bud and flower are both handsome. Color, blush, shaded light salmonpink; distinct and desirable.

MRS. Wax. H. CUTBUSH-Flowers the delicate pink of Dorothy Perkins.

PERLE d'OR-Coppery-orange, changing to fawn.

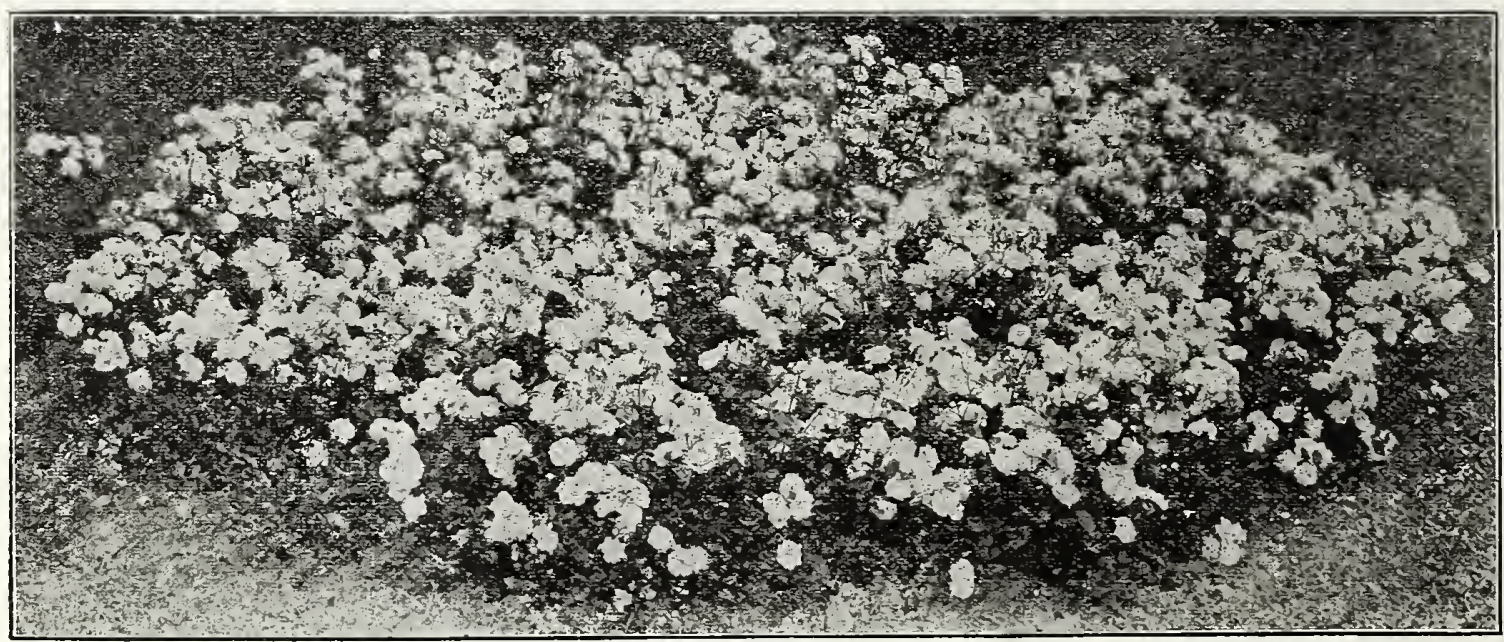

Baby Dorothy.

\section{New Polyantha, or Baby Roses}

\section{Price 25 Cents Each; Two-Year Plants, 60 Cents.}

BABY Dorothy-This is a glorious Rose. Flowers resemble the Dorothy Perkins. Completely hides the plant with its bloom.

BARY ECHO-The best Polyantha produced. Color rosy-flesh color. Of splendid strong growth and freedom of bloom, which are of wonderful keeping. qualities either on or off the plant. This is the improved Baby Tausendschoen. It has more substance and more color, and is the best of all Baby Roses for pot culture. Be sure and try this one.

BABY TAUSENDCHOEN, or THOUSAND BEACTIES-Its flowers are large, so much like Thousand Beauties, that it has been rechristened Baby Thousand Beauties. It is a bush form of the Thousand Beauties, having all the charm of the variable coloring in its flowers that its parent has, being firm, white, delicately flushed pink, changing to deep rosy-carmine. A splendid Rose. Try it.

IOITH CAVELL-Bright crimson; white eye; very beautiful. One of the best new Baby Roses.

ETOILE LUISANTE Or BABY HERRIOT-Just picture to yourself the Fairy or Sweetheart Rose ("Cecile Brunner"), colored up like the Daily Mail more brilliant than when that variety is at its best, and you will have some conception of the beauty of this little gem which on account of the similarity in color has been known among the cut flower trade as Baby Herriot. Its color is a shrimp-pink with intense, coppery-scarlet suffusion, the base of the petals golden-yellow which intensifies and lightens up its high colors. Plant is of free growth and floriferous. We are certain that Baby Herriot will please everyone.

GEORGE ELGER - A lovely little golden-yellow Polyantha Rose, with a good admixture of Tea blood; like all of its class, it is free in growth free in bloom, with small, glossy foliage produced in profusion. The dainty little pointed yellow buds open into pretty little symmetrical Roses. Will prove a very popular corsage variety; is grown in quantity now for this purpose.

GRUSS AN AACHEN-Yellowish-rose colored with salmon-pink and red shadings; full, strong, free blooming and disease proof; erect and of moderate growth. Owing to the size and beauty of its flowers and its symmetrical growth, this variety is highly recommended for low, bright massing.

LE YAINE-Dwarf, perpetual flowering Polyantha. Semi-double flowers, bright salmon-rose at the edges, rosy-blush inside. Bf fifteen to forty flowers. Has fine keeping qualities.

MLLE. FRANCISQUE FAVRE - Dwarf Polyantha. Robust in growth, quite continuous in bloom, flowering in large trusses of single flowers. Color, velvety crimson, with large silver-white eye. Extremely showy, 


\section{New Polyantha, or Baby Roses-Concluded}

\section{Price, 25 Cents Each; Two-Year Old Plants, 60 Cents Each}

OnLENNS-The showiest and prettiest of all the Baby Ramblers. This charming and dainty Rose is of beautiful rounded habit and is a huge bouquet of deep cerise or Geranium-pink, with distinct showy center of pure white; florets not crowded, but of beautiful arrangement, making as a chole a charming combination that cannot be beaten. Color is irresistible. Plant grows telle" in their lasting qualities. medal. Pop, "Baby Doll"-This delightful little "Sweet new, and quite startling in its brilliancy, golden yellow tipped with clear, bright cerise. The foliage is narrow, long and sharply pointed, a deep glossy green-a very beautiful setting for the lovely little doll roses, a bench of "Baby Doll" being an even parterre of delicious color.

\section{"Famous" Rose Collection for Garden Planting}

We guarantee that no better Twelve Roses for the Garden were ever offered than this "Famous 'Collection. Try them. Price, 25 cents each; the entire twelve for \$2.50. Two-5ear-old plants, 50 cents each; the entire twelve for \$5.00.

ANTOINE RIVOIRE-This is the famous Mrs. Taft Rose of the fashionable liastern markets. This Rose is in a class by itself; no Rose ever produced has such substance of petal; color creamy-
white with rainbow tints; a beauty and a wonder. BESSIE BROWN-A Rose of transcendent beauty; of the largest size; color pearly-white with a delicate tinge of fawn

ETOILE DE FRANCE-For the best red garden Rose it lies between this one, Rhea Reid and Helen Gould. Some say one and some say the other.

E'TOILE DE LYON-Still the best large golden-yellow Rose.

HELEN GOULD-A rich red Rose that is a great bloomer; the shade of red has been described best as a watermelon-red; elegant.

HELEV GOOD (The Beauty Cochet)- What the in troducers say: "This is a true Cochet Rose, and after two years' trial in the garden we pronounce it as good if not better than any Rose for the garden ever sent out. We bought the entire stock of this Rose, paying $\$ 1,000$ for two plants, this being by far the highest recorded price ever paid for any Rose. The color is a delicate yellow suffused with pink, each petal edged deeper, very chaste and beautiful. The color, with its immense size and exquisite form, makes it without question the greatest Tea Rose ever introduced, and

we are proud to have brought it out."
KAISERIN AUGUSTA VICTORIA - A grand white garden Rose that has stood the test of time. Full and double; fine buds and flowers.

MAMAN COCHET (The Queen of all Garden Roses) Such beauty and exquisite form as is possessed by this variety is well-nigh marvelous, and cannot be seen in any other Rose we know of. The buds are beautiful large, full and firm and elegantly pointed; as they expand they show great depth and richness sometimes measuring two and a half inches from base to tip. Flowers superb when open, extra large, perfectly double and of

splendid substance. Small pot plants will in the open ground quickly make large, strong bushes and produce on lone stiff stems, great number of perfect flowers that are enchanting in fra grance and delicate brightness. The color is rich, clear pink, changing to a silvery-rose. As we is worth a whole collection of poor ones.

PRESIDENT TAFT (MCCullough, 1908.)-This Rose was raised in Cincinnati, the home of President Taft, and let us say right here, while some of you may not admire the President himself, you will one and all, admire the Rose given his name. It is without question the most remarkable of all pink roses. It has a shining, intense, deep pink color possessed by no other Rose. It is a fin grower, free bloomer, good size and form, fra grant and in a class by itself as to color. Our Mr. Frank Good, who is probably familiar with more Roses than any man in America, says: "Talk all you want to about the Rose President Taft, and then vou will not say enough."

RADIA N CE (Cook, 1909.) - A brilliant rosy-carmine displaying beautiful rich and opaline-pink tints in the open flower. The form is fine, largest size and full, with cupped is delightfully fragrant. This is a superior Rose.

WHITE MAMAN COCHET (No Finer Rose Than This)-This Rose attracted our attention from the very first time we ever saw it in flower. It is of the largest size, and as you will notice, the flower is built up, or lounded and very double. The color is a pure snow-white. Sometimes outdoors it is tinged Pink, which only adds to its great beauty. No Rose surpasses it in vigorous growth and in the immense size of its buds and flowersindeed, nothing in the Tea family approaches i in size. Deliciously fragrant.

VVI. R SUITH This Rose has several names, such as Charles Dingee, Jeanette Heller, Maiden's Blush, etc. Color delicate blush. It has no superior as a garden Rose.

\section{"Home" Collection of Ever-Blooming Roses FOR WINTER BLOOMING}

Price, 20 cents each. Six “Home" Roses for only \$1.00.

We have made a selection of the very best Roses for winter blooming, embracing a wide range of color. We can recommend this collection to all who desire to grow Roses in the house during winter, Equally good for planting in the garden

EAFRANo-The old standby for a winter bloomer: lovely saffron-colored buds of the most delicious fragrance.

PAPA GONTIER-Deep red; very free and sweet. RRIDESMAID-This is a fit companion for the Bride. ing. The best deep the millions for winter bloom

BON SILENE-Deep rose, illumined with bright red; a grand winter bloomer; very sweet.

HE BRIDE-Best winter blooming white Rose planted by the millions by growers of cut flowers; none finer.

ISABELLA SPRUN'T - Flowers freely during the winter; flowers of the richest yellow color.

REMEMBER-This entire collection of wix "HOME" ROSES for only \$1.00; per single plant, 20 cents. These six "HOME" ROSEs in two year size for only \$2.50 or 50 cents each.

\section{The Newer and More Scarce Hybrid Roses}

Price, 30 cents each, except where noted. Two-yenr size, 75 cents each, except where noted. These Roses are hardy and suitable for planting in cold climates. All are extrenely fragrant.

AERICAN REAUTY-Color red, with touches of crimson, and intensely fragrant. No Rose has a sweeter or more penetrating fragrance th a $\mathrm{n}$ American Beauty. A most beautiful Rose and a great favorite. 25 cents: two-year plants, $\$ 1.00$. ARTHUR R. GOODWIN-The color is coppery orange-red, passing to salmon-pink as the flowers expand. A superb combination of color.

GEORGE DICKSON-Velvety black scarlet-crimson with brilliant scarlet reflexed tips, with heavy and unique pure crimson-maroon veining on reverso. HIS MAJESTY (The King of Roses)-Dark, deep crimson; superb. Mr-Crowell, the noted rosarian, says the best of all red Roses.

HUGH DICKSON-Intense velvety crimson, shaded scarlet.

J. B. CLARK-An intense deep scarlet, shaded black

KING GEORGE $\mathbf{V}$-Color rich blackish-crimson, Hushed deep velvety crimson. 


\section{The Newer and More Scarce Hybrid Roses-Concluded}

MADA ME EDW ARD HERIRIOTT-“The Daily Mail

Rose." Winner of the gold cup which was offered by the London Daily Mail for the best new Rose. M. Pernet Ducher describes its color as follows: "Buas coral-red, shaded with yellow at the base, the open flowers of medium size, semi-double, are of a superb coral-red, shaded with yellow and bright rosy-scarlet passing to a shrimp-red." 50 cents; two-year plants, $\$ 1.00$.

MRS. JOHN LAIG-Immense size; bright shellpink.

NEW CENTURY - A grand Rose that is entirely hardy bearing beautiful silvery pink flowers in

PIN clusters. This Rose is in bloom all the time. This is a wonderful new Rose, just as fine in its way as a pink Rose as White American Beauty is as a white Rose. Extra fine; brilliant clear pink.
SIR THOMAs LIPToN (Conard, 1905)-(R.) The best pure white Rugosa Rose. Strong and vigdouble; pure snow-white. Fragrant.

WHITE AMERICAN BEAUTY, OF FRAU ICARI DRUSCHKI-This grand white Rose has become renowned as the very highest type of its class and the best snow-white Rose ever introduced. It is an extraordinarily strong grower, and has the vigor and hardiness of an oak. Its magnificent flowers are nothing less than glorious-immense in size and produced with great freedom. Color is a marvelous white, without a tinge of yellow or any other shade. A true paper-white, the stand ard by which all white Roses are judged. We grow "White American Beauty" literally by the thousands. 40 cents: two-year plants, s1.00.

\section{Standard Varieties of Hybrid Perpetual Roses} HARDY EVERYWHERE

Price, 25 cents each; five for \$1.00. Two-year slze, 60 cents; three for $\$ 1.50$.

ANNE DE DUESBACI (Glory of Parls)-A lovely carmine-rose.

BLACK PRINCE-A rich, brilliant dark crimson.

BOULE DE NEIGE (Ball of snow)-Pure white; fille. CAPTAIN CHRISTY - Delicate peach-blow pink. center richer in color; large and full.

CLIO-Delicate flesh, with center of rosy-pink. CONRAD F. IEYER-Clear flesh-pink: 4 in. across. DUC DE ROHAN-Clear, dazzling bright red; extra. EUGENE FURST-Deep red sliaded crimson; fine. FRA NCOES LEVET-China-pink; delicately shaded

GENEIRAL JACQUEMINOT-Known as "General Jack;" shining crimson.

GLOIPE LYONNAISE-Pale shade of chamois or salmon-yellow.
JURILFE-A pure crimson, with shadings of $\mathrm{ma}$ roon; a grand Rose from erery point of view.

MADAME CHAS. WOOD-Cherry-red; free bloomer. MADAME MASSON-Bright, rich crimson; a gem.

HADAMF PLANTIER-This is the ironclad white cemetery Rose.

MAGNA CHAR'TA-Clear, deep pink, flushed rose.

IA RSHALL P. WILDER - Scarlet-crimson, richly shaded maroon.

PACL NEYRON-Deep rose or bright pink; large

PRINCE CAMILLE DE ROHAN-Deep, rich, velvety crimson.

ULRICH BRUNNER-Glowing crimson flamed with scarlet.

\section{The New Hardy Climbing Roses Hardy Everywhere}

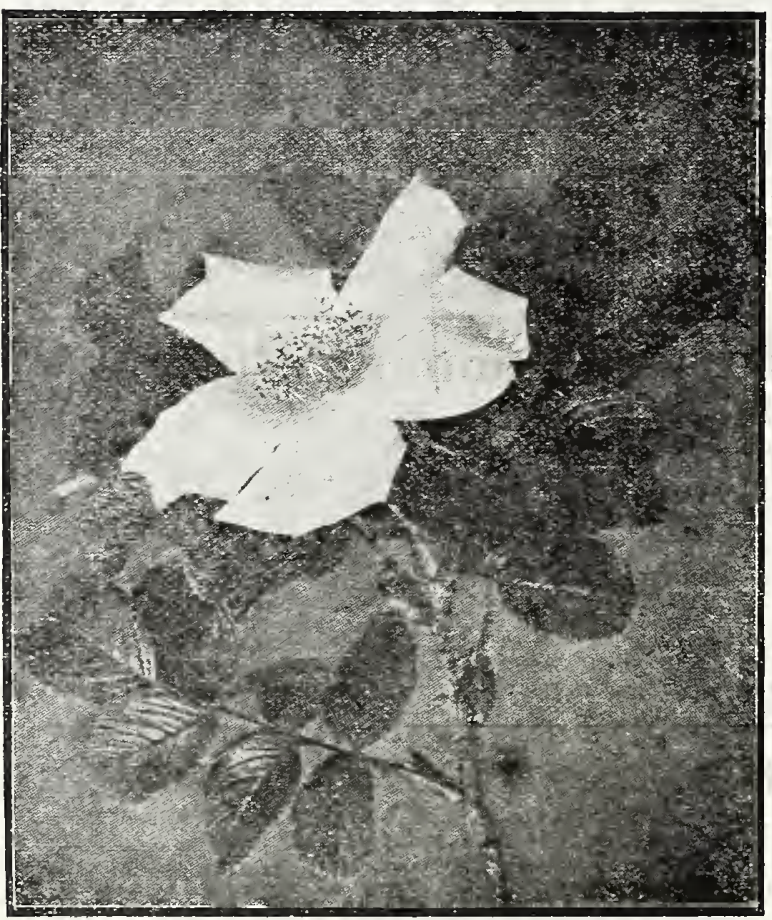

American Pillar.

ALIDA LOVETT-Both buds and flowers are large, are of ideal form, are held on stiff stems a foot and a half to two feet long and the color is a lively bright shell-pink with shadings of rich sulphur at the base of petals-a combination that is both novel and beautiful. The flowers are of remarkable substance and long lived, whether cut or left to remain upon the plant, and are pleasantly perfumed. It is very much brighter and more cheerful in color with larger flowers than those of the justly popular Dr. Van Fleet Rose. 35 cents. Two-year plants, 75 cents.

AMEIRICAN PILLAR-The flowers are of enormous size, three to four inches across, of a lovely shade of apple-blossom pink, with a clear white eye and cluster of yellow stamens. These flowers are borne in immense bunches. They last in perfection a long time, and are followed by brilliant red hips of berries, which are carried late into the winter. 25 cents. Two-year plants, 60 cents.

BESS LOVETT-Resembles Climbing American Beauty in shape of bloom, but is very much brighter in color and much more fragrant. The flowel's are clear, bright red, of good size, and of double, full. cupped form, lasting a long time ill good condition. Beautiful in bud and bloom and the most fragrant of the Climbing Roses. A vigorous grower and free bloomer. The large glossy foliage, like that of Silver Moon, greatly enhances the beauty of the flowers. $2 \pi$ cents each. Twoyear plants, 60 cents.

CHRISTINE WIIGIT, Or PINK CLIMHING A.MERICAN BEAUTY - This is identical with the Red Climbing American Beauty described next below this rarietr: flowers four inches in diameter; color bright, clear pink; immense. Try it; a flne companion for Climbing American Beauty. 25 cents. Two-year plants, 60 cents.

CLIMHING A MERICAN HEAUTT-Samé color, size and fragrance as American Beauty, with the addition of the climbing habit. Good foliage and better blooming qualities. One plant of this new Rose will produce twenty times as many flowers in June as the old American Beauty, besides blooming occasionally during the summer. Blooms three to four inches across; has proved perfectly hardy and stands heat and drought as well as any Rose in our collection. 35 cents. Twoyear plants, 75 cents.

GARDENI (The Hardy Marechal Neil)-This grand Rose has proven itself hardy in Virginia and Tennessee. It is a deep golden-yellow of the largest size, 25 cents, Two-year plants, 60 cents, 


\section{The New Hardy Climbing Roses-Concluded HARDY EVERYWHERE}

GOLDFINCH -A deep golden-yellow climbing Rose, called by some the Yellow Thousand Beauties; a glorious Rose. 25 cents. 'Two-year plants, 60 cents. PAUL'S CARMINE PILLAR - The earliest of the Climbing Roses to come into flower. Color a rich rosy-carmine with white eye, 25 cents. 'Two-year wiants, 60 cents.

PAUL'S SCARLET CLIMBER-The flowers of this superb Rose are vivid scarlet shaded with bright crimson. A gold medal Rose of England. A new shade in Climbing Roses. 35 cents. Two-year plants, 75 cents.

FED DOROTHY PERKINS, or EXCELSA-The defects of Crimson Rambler are its unsightly foliage in unseasonable weather and its defoliation by insects; the infusion of Wichuraiana blood assures an ornamental climber which is nearly evergreen, and this will assure this lovely crimsonscarlet pillar Rose a place in every American garden, for it is quite hardy in addition to all its other fine points. The flowers are very double, produced in large trusses of thirty to forty, and almost every eye on a shoot produces large clustel's of lowers. The color is intense crimsonmaroon the tips of the petals tinged with scarlet. The finest of all red Climbing Roses. 25e. Twoyear plants, 60 cents.

ROSARIE, Or PINK THOUSAND BEAUTIES-This is a bright pink form of that famous Rose, "Thou. sand Beauties." A grand Rose from any standpoint. 25 cents. Two-year plants, 60 cents.

SHOWER OF GOLD-This variety produces masses of flowers in large clusters. The color is a deep golden-yellow, with orange shadings in the cen- ter. Enormous iateral branches are produced, which are densely clad with glossy green foliage that resists disease. This fills the "long felt want" for a hardy yellow Climbing Rose. 2. cents. Two-year plants, 60 cents.

SILVER MoON-Flowers very large, four and onehalf inches and over in diameter. Pure white in color; petals of great substance, beautifully cupped, forming a clematis-like flower. The large bunch of yellow stamens in the center adds its attractiveness. These flowers are borne on strong stems twelve to eighteen inches long, and are delicately scented. The plant is a strong grower, with large, glossy, bronze-green foliage. 25 cents. 'Two-year piants, 60 cents.

TAUSENDSCHOEN, or TIOUSAND BEATTIES-A Climbing Rose that comes to us from Germany. The flowers upon first opening are the most delicate shade of pink ever seen in a Rose, might be described as a white delicate flushed pink, changing to rosy-carmine. It gets its name from its many flowers and the variation in coloring. This Rose is sweeping the country like a prairie fire. 25 cents. Two-year plants, 60 cents.

VEncIIENBA $U$ (The Wonderful Nerv Blue Rose) - This is a Rambler, and will thrive anywhere, being perfectly hardy. It has created a great Stir in the Rose World, for the talk of a Blue Rose has been going on since time immemolial It first opens a pink color, quickly changing to a decided violet blue. When the plant is in full bloom it presents a startling effect. 25 cents.
Two-year plants, 60 ccnts.

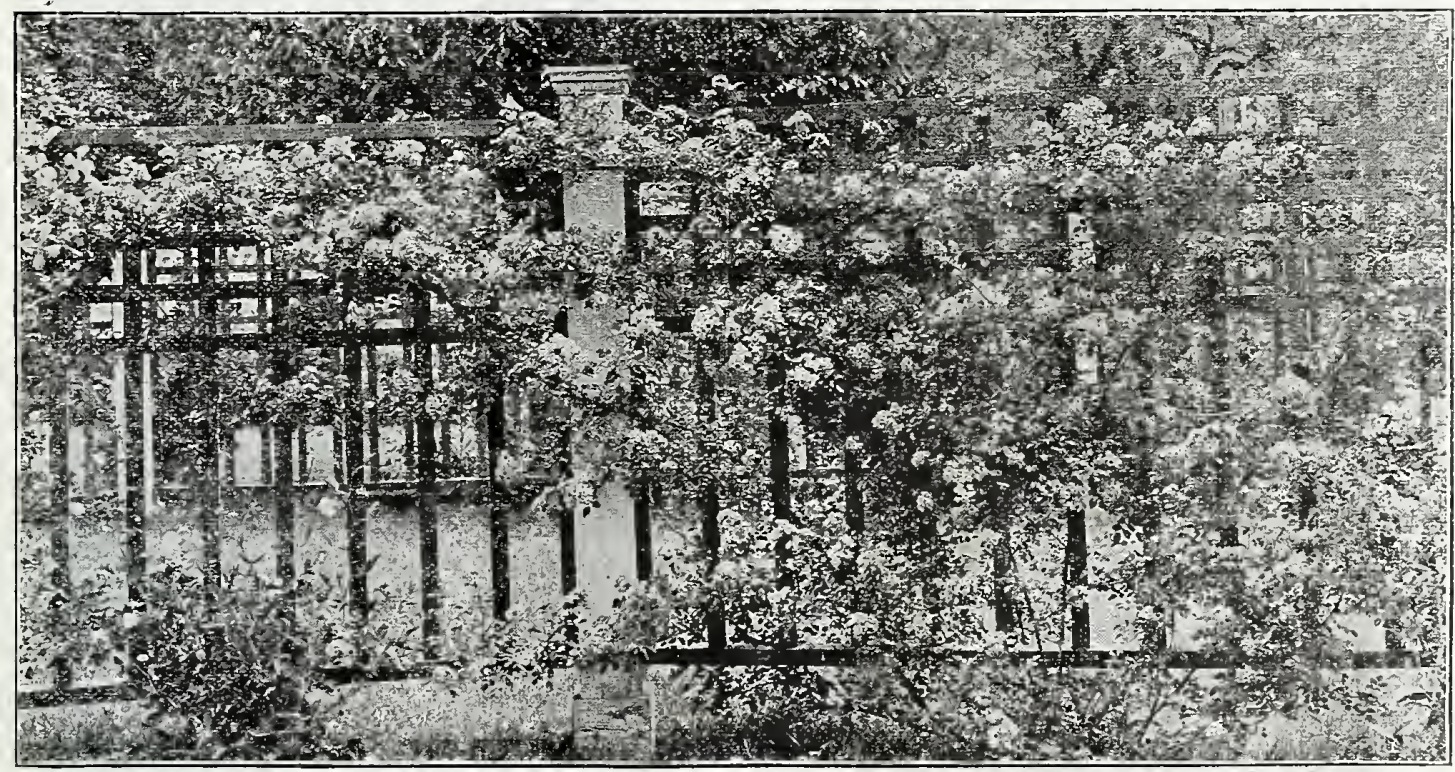

\section{Hardy Climbing Roses, Including Ramblers}

Price, 25 cents each; any five por $\$ 1.00$. Two-year-old plants, 50 cents; three for $\$ 1.25$.

AVIATEUR BLERIOT - Saffron-yellow, go l d e $\mathrm{n}$ (1)

BALTLORE BELLE-Blush-white, in large clusters

CLIHBING BABY RAMBLER-Bright red; blooms all the time.

CRIYSOX IRAMBLR-The flowers are in huge red painicles.

OR. W. YAX FLEET-Delicate shade of flesh-pink. Doro'iHY PLRKINS-A beautiful shell-pink; full EMPREsS of CHINA - Bright pink, in large FLower of FAIRCHILD - $\mathrm{T}$ he everblooming FLowER OF FAI
Crimson Rambler.
HXAWTHA - Brilliant ruby-carmine with clear

LADY GAY - Very double, deep pink, in large clusters.

MADA ME ALFRED CARRIERE-Pure white suffused with yellow at base of petals.

MARY WASHINGTON - Pure white; perfectly double; fine.

PHILADELI'IIA RAMBLER - Clusters of darkest rimson.

PRAIRIE QUEEX-The old standby red climber.

WHITE DOROTHY PERIiIS-Pure white, in immense clusters.

YELLOW RAMBLER (Aglaia)-Light lemon-yellow. 


\section{MOSS ROSES}

These are probably a sport of the Cabbage Rose. The origin of the double Moss Rose is left to conjecture. They have always been favorites, for what can be more elegant than the bud of the Moss Rose and more delicious than its fragrance? Perfectly hardy.

ELIZABETH ROWE-This is an old favorite with | MocsSELINE-Pure white flower, buds heavily and its large deep pink buds well mossed. A beauty. HENRI MARTIN-Iarge, full flower of deep red; beautifully mossed.

PRINCESS ADELAIDE-Deep blush-pink with buds well mossed; fragrant.

\section{MISCELLANEOUS ROSES}

Under this heading are listed all the Roses not embraced in the different families or types that we name in the preceding pages.

A Mons. The Pink Flowering Cherokee Rose-The flowers are the same as the White Flowering Cherokee, except that the color is a glowing pink with a golden-yellow center. Resembles huge apple blossoms. 25 cents each. Two-sear plants, 60 cents.

LAEVIGATA, the single white Cherokee RoseThis is the famous Cherokee Rose so well known in California. Large, pure white flowers with center filled with golden-yellow anthers. 25 cents each. Tro-year piants, 60 cents.

WICHURAIANA, OT MEMORIAL ROSE-It is difficult to conceive anything more appropriate, beautiful and enduring for covering graves and plots in cemeteries than the Hardy Memorial Rose. It creeps along the ground as closely as an Ivy. The flowers are produced in lavish profusion in July. They are single, pure white, with a golden-yellow disc, fire to six inches in circumference. It is also immensely valuable as a Climbing Rose, covering arches, fences, etc. 25 cents each. Two-sear plants, 60 cents.

WHITE BANICIA, or LADY BANKS-Pure white: violet fragrance. 25 cents each. Two-year plants. 60 cents.

YELLOW BANKSIA, or LADY BANKS-Deep yellow; violet fragrance. 25 cents each. Two-year plants, 60 cents.

\section{GLADIOLI}

Their easy culture appeals to all, and the freedom from disease and insect pests is another great asset. They associate so well with all garden flowers, but above all are the decorative possibilities both as a cut flower subject and also in the garden. The collection we here ofier is unsurpassed and will be a source of great delight to all who plant them. The flowers last a long time when cut. Do not be stingy in planting Gladioli. but plant by the dozen, or even by the hundred. Varieties marked with an asterisk $(*)$ are particularly fine for forcing.

The collection we offer embraces the introductions of such noted hybridizers as Betscher, Childs, Diener, Kunderd and others. It includes the best of the new Ruffled varieties as well as the best of the new Primulinus group.

ADELINA PATTI-Very large, of the richest dark violet color; has many ađmirers. Each, 50c; dozen, \$5.00.

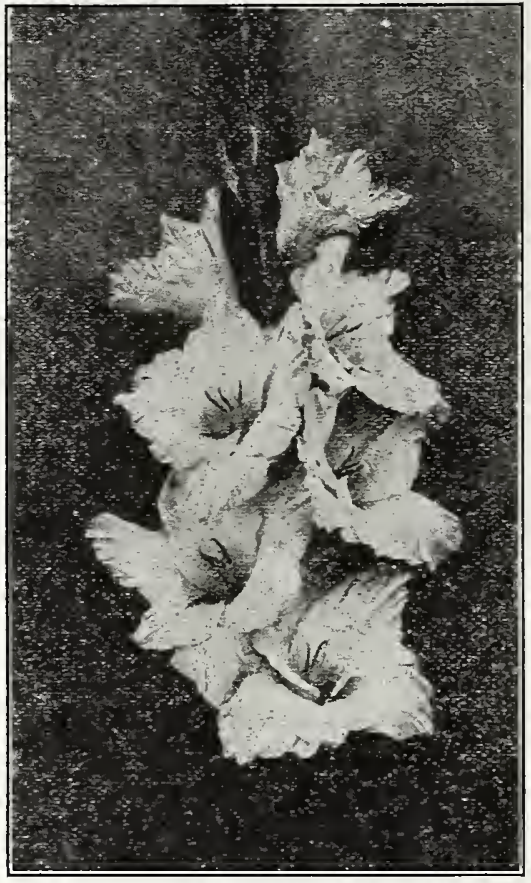

Adeline Kent.

ADELINE KENT (Ruffled) - Delicate light rosepink; straw colored throat with ruby dashes; petals are hearily ruffled from edges into the center. Exquisite orchid-like coloring. Each, 50e; dozen, $\mathbf{8 5 . 0 0}$.
ALICE TIPLADX - Without question the queen of the Primulinus trpe. The stalk is fully three and a half feet high, lined with twelve enormous flowers. The color is a soft coppery-bronze or pure orange. In color texture and contour nothing surpasses this rariety; either in the garden or cut it is extremely decoratire. Each, 35e; dozen, \$3.50.

*AJictricA-Too much cannot be said of this beautiful dainty pink, tinted lavender. Each, 5c; dozen, 50 cents.

A NERICAY BEAUTY (Diener)-Brilliant American Beauty color with creamy-yellow throat. One spike opening a large number of flowers at one time forms an immense bouquet of great beauty. Flowers six to seven inches in diameter. Spikes four to five feet high. Each, \$1.00.

AHETHYST-A remarkedly strong, open flower of a deep amethyst color, slightly suffused rose. Each, asc.

ANA EBERITS-A little difierent in color from anything on the market. Dark velvety Nell rose; throat deeper shaded. Each, 10c; dozen, $\$ 1.00$.

A PolLo-Color a deep Begonia-rose, almost scarlet, with delicate white markings in throat. Each, 7c; dozen, $75 \mathrm{c}$; hundred, $\$ 5.00$.

ARIZONA ROSE (Kunderd)-Charming shade of finest old rose pink, almost a self-color. Beautiful form and texture. Very choice. Each, 10e; dozen, $\$ 1.00$.

*UGUSTA-Opens delicate pink, changing to pure white. If cut just as the first bud begins to open and kept inside it opens pure white with blue anthers. Each, 6e; dozen, 60c; hundred, \$4.50.

ACTUMN QELEN-This beautiful variety is known in Cauada as "Lady Borden." Cream yellow upper petals suffused with peach blossom pink, lower petals striped Carmine-red. A most pleasing combination. Each, 40e: dozen, \$4.00.

BARON JOSEF IILOT-One of the finest deep violet-purple, very dark on petal tips; light on upper petals in throat, lower petal a rich pansyviolet with flock of primrose-vellow on midvein. anthers lilac. Each, 7c; doxen, 75c; hundred, \$5.00.

BERXICE - Light yellow, buff and pink marks. Each, 10c.

HERTREX, the Beautiful-Iustrous white with pencil stripes of lilac in throat. Each, 10c; dozen, $\$ 1.00$.

BEST VIOLET-A rich violet color; one of the best. Each, 10c; dozen, $\$ 1.00$. 


\section{GLADIOLI-Continued}

BLACK HAWK-Dark red, with almost black throat. Each, 15c.

BLUE JAY-Beautiful pale Ageratum-blue, overlaid darker with white blotch and having a red stripe on tongue of lower petals. Each, 15e.

BRENCILEYENSIS-The mother of all Gladiolus, Roseate-orange, outer edge of petal penciled purplish-brown, throat touched with canary-yellow and lines of old carmine-red; anthers lilac. Each, 5e; dozen, s0e; hundred, $\$ 3.50$.

BU'TTERFLY (Ruffled) (Priminulus) - A delicate salmon-pink, nicely ruffled. Each, 35c.

CANARY BIRD (Childs) - Pale buttercup-yellow. deeper in throat, petals lanceolate. One of the best yellows. Waeh, 15e; dozen, \$1.50.

CAP'TAIN ASHEIR CARTER BAIKER-A very fine red, spikes three to four feet, flowers five inches in diameter. Each, 15e.

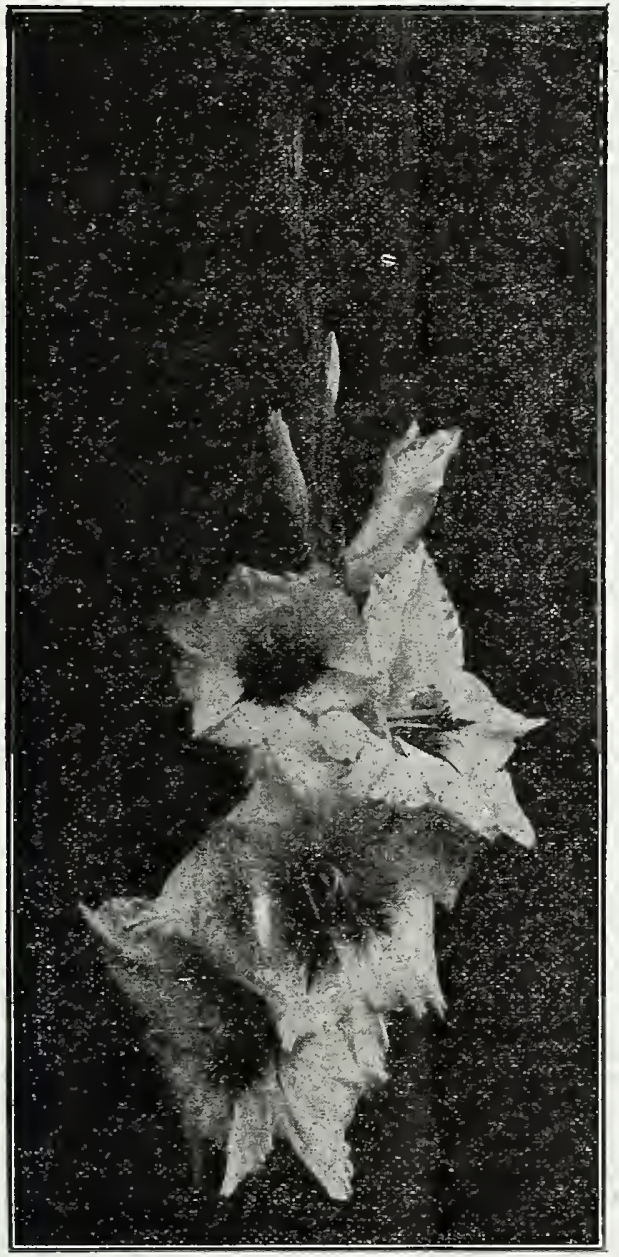

Caroline Frear Burke.

CAROLINE FREAR BURKE-Pure white with brilliant ruby throat: flowers 7 inches in diameter, spikes 4 to 5 feet high. Each, 25c.

CATHERINE- Wonderful grayish light blue, lower petals a deeper blue with brownish-red -spot. Each, 50c; dozen, $\$ 5.00$.

CHATEAU THIERY-Dark orange-rose with yellow spots. Each, 50c.

* CHICAGO WHITE-Pure white with narrow lines, crimson-carmine on midribs of three lower petals surrounded by a little amber. Each, 7e; dozen, 75e; hundred, $\$ 5.00$.

CLARICE-Rich rose pink; flaked and suffused with deeper tint. Each, 10c.
CLEAR EYE (New) - Tall, e a r ly, robust strong grower; long spikes; broad dark green foliage; rich deep scarlet with a pronounced white center; broad flower of a fine form; very early. Certificated London 1912; Haarlem, 1913. Wacli, 30e; dozen, $\$ 3.00$

COLUMBIA-Light, orange-scarlet freely blotched and penciled with blush-purple. Throat freely mottled. Each, Te; doxen, 75e; hundred, \$5.00.

CoNspICUOUS-Light blue, striped with a yellow blotch bordered with darker blue; resembles : butterfly. Each, \$1.50.

COSTA RICA-White, overlaid with pink, flowers moderate size. Each, 25c.

*CRACKER JACK-Dark red, of a rich velvety texture; blotch of maroon on a yellow ground. Each, 15c.

"CRIYSON GLOW-Glorious, brilliant, satiny "Crimson Glow" a color that is fetching and pleasing to all. Wach, 50e; doxen, \$5.00.

CRYSTAL WHiTE-Clear, gistening white with a small mark of Tyrian lose in the throat. Spike tall and straight. Strong grower. Each, 15e.

*DAISY RAND-Ivory-white, heavily splashed with pink, giving appearance of solid pink flower. Each, 25e; dozen, \$2.50.

DAVID STARR JORDAN - Immense flame colored, with lighter speckled throat; flowers very open, like immense Amaryllis, with fine, wiry upright stems. Wach, 25e.

*DAWN (Traey) - The most beautiful coral-pink Gladiolus ever offered. Each, 20e; dozen, \$2.00.

* DELICE-A choice, early variety. Clear, dainty pink, self-colored. Each, 15e.

DIENER'S WHITE-Milk white with faint tinge of pink in throat, awarded Gold Medal Panama Pacific Exposition. Each, $\$ 3.00$.

*DORO'THY MeKIBBEN (Ruffled) - The new ruffled pink, a pure apple-blossom tint, extraordinarily early. Elegantly ruffled. Each, 50e; dozen, $\$ 5.00$.

*Dominion (Synomyn Red Emperor)-A pure deep scarlet or blood-red; immense flower of great substance, well place upon a tall spike. Each, 35c: dozen, $\$ 3.50$; hundred, $\$ 25.00$.

DORA IRRAIS-A much improved yellow; color sulphur yellow with dark carmine spots; flowers very large and open; this was much admired last year when exhibited. Eaeh, 20e; doxen, \$2.00.

DR. LINCOLN COTHRAN - Salmon-pink, b l u e striped, yellow throat, flowers of good size, spike medium size. Each, 25e.

EAIRY PINK-Light pink with dark blotch. Each, 250

*EIECTRA-Very large brilliant scarlet of a bright and pleasing brick-red with small light blotch. Each, Te; diozen, 75e; humdred, $\$ 5.00$.

ELIZABETH GERBERDING (Ruffled)-Shell-pink, with speckled center of ruby and yellow; heavily ruffled; spikes large and full. Each, 50c; doxen, $\$ 5.00$.

ELKHART (1917) - Violet purple, deeper throat blotch. An extraordinary rich color. Unusually choice and fine. Each, 50e; dozen, \$5.00.

ELSE ROSE - Cattleya pink, a blending of rose pink, shading to white with creamy throat, orchid flowering. Each, 25e.

EMILIE ASHE (Ruffled)-Creamy snow-white, small cerise blotches in lower petals, heavily ruffled. Each, $\$ 1.00$.

EMPRESS OF INDIA-The darkest of all. Very dark rich mahogany-red. Each, 7e; dozen, 75e; hundred, $\$ 5.00$.

*EURoPA - White as the driven snow. Perfect form, with many pure white blooms open at once. Each, 20e; dozen, \$2.00; hundred, \$15.00.

* EVELYN IIIRTLAND-The flowers are a beautifu shade of rosy-pink, darker at the edges, fading to shell-pink at the center, with brilliant scarlet blotches on lower petals. Entire flower showing a glistening, sparkling luster. Each, 20c; dozen, $\$ 200$.

FAIRFAX-Solid magenta, lips of throat light yellow with a deep magenta spot. Each, 15e.

* FA UST (Synonym Harvard) - A perfect Harvard crimson in color. Wach, 7e; dozen, 75e; hundred, $\$ 5.00$.

FLor A-Beautiful deep golden-yellow, large pure flowers. Each, 50c. 


\section{GLADIOLI-Continued}

FRANI J. STMUIES (Ruffled)-Salmon-rose pink with red center, ruffled edges. Each, 75e; dozen, $\$ 5.00$.

FRED WIGBAN-Bright red with a strong yellow throat. Each, 6c; dozen, 60c; hundred, \$5.00.

GENEVIEVE BOTHIX-Deep pink, thickly overlaid with steel blue, unusual flower. Each, 25c.

GIANT FAWN - Very large, deep fawn yellow, splendid substance, red line in throat. Each 25c. IANT WHITE (Kunderd)-An extra large white of great size and substance. Pure white with elegant slight markings on lower petals. Each, 15c.

GLARE-The most unique color among Glads. It is a red of indescribable hue-"Intense," "BrilGLORY (Rufled)-The opening buds are of a soft creamy tint, edged with pink, but as the flowers expand the ground color changes to rich ivorywhite suffused with pale lavender, which is deeper on the edges. The lower petals are buffish, with a pale crimson stripe through the center; the throat is penciled with buff and crimson. Each, 10c: dozen, $\$ 1.00$; hundred, $\$ 5.00$.

*GLOR Y OF HOLLAND-A new white with slight tinting of blush-pink and anthers of delicate lavender. Each, $6 \mathrm{c} ;$ dozen, $60 \mathrm{c}$; hundred, $\$ 4.00$.

GLORY OF KEXNEMERLAND-The greatest attraction at the Michigan State Fair. Beautiful panded. An extremely showy variety. Each, \$1.50 dozen, $\$ 10.00$.

GLORY OF NOORDWYK-A new yellow, beautiful soft canary shade. Each, \$1.00; dozen, \$10.00.

GOLD DROP (Primulinus) - An extra large pure, deep yellow with beautiful red line on petals. Each, \$1.00.

GOLDEN MEASURE-The great yellow Gladiolus. A true pure golden-yellow absolutely free from any blotch or marking. Each, \$4.00.

GOLDEN IING-A brilliant golden-vellow, with intense crimson blotch in throat, giving a magnificent effect. Flowers well opened and well set on a very graceful spike. One of the best of the yel

GOLDEN WEST-Color clear orange-scarlet, lower petals blazed with golden-yellow faintly suffused with violet shadings. Don't miss it. Each, 7c: flozen, $65 \mathrm{c}$; hundred, \$5.00.

GRENADIER-Flowers and spikes are large, compact and full, the wrinkled edges of the petals giving a general ruffled appearance. The ground color is scarlet overlaid with orange. Each, 15c.

GRETCHEN ZANG-A most beautiful soft melting shade of pink, blending into deep salmon on the lower petals. Approaches the brilliant coloring of the Beaute Poitevine Geranium. Each, 15e; dgzen, \$1.50.

* FAILEY - A delicate salmon-pink. Each, Ge; dozeu, 60c; hundred, $\$ 4.00$.

HAWAII-Rose-pink, light pink center, big brown spot in center of lower petal; clean grower, e

HELEY TODD - Light rose-pink with deep colored seam around entire edge of flower; deep scarlet center. Each, 15c.

* HERADA-The blooms are pure mauve, glistening and clear. Each, 15e; dozen, $\$ \mathbf{1 . 5 0}$.

IDA VAN-Orange-red of brilliant tint. Forty-two inches. Fach, 10e; dozen, \$1.00; hundred, \$7.00.

INA COLLINS-Deep rose pink, underlaid with lilac orchid flowering, flowers 5 in. in diameter, spike four to five feet. Wach, 50c.

INDEPEXDEXCE-A brilliant Begonia-pink, with richly marked throat. Each, 6c; dozen, 60c; hunlred, \$4.00.

INTENSITY-Scarlet, light center. Each, 10e.

ISAAC BVCHANAN-Very fine yellow. Each, 10e; elozen, \$1.00.

ACK LOYDOX - L ight salman with brilliant orange flame stripes; golden yellow throat with ruby striped center; flowers 5 inches in diameter, spikes 5 to 6 feet high. Each, 50c.

JEAN DIEULAFOY (Lemoine) - A lovely cream color, with carmine blotch. Excellent for bouquets. Each, 10c; dozen, \$1.00.

JESSIE-A velvety dark red, early. Each, 10c.

JOHN MERLE COULTER-Rich scarlet, dark maroon (almost black) throat, slightly overlaid with feet hish. Each, 25c.
JONATHAN WEBB - Light scarlet, finely painted white, and maroon mottled center; very showy variety; makes elegant lily-like spike with wide open flowers. Each, 25c.

JUMBO-Large light pink. Each, 60c.

KLONDIKE-Clear primrose yellow with crimson blotch. Flowers round, on a strong spike. Early bloomer and of dwarf habit. Each, 10c.

I.APIGERA-A beautiful rose-pink with trumpetshaped flowers. Each, 25e; dozen, \$2.50.

*LIEBESFEUER (Love's Fire)-Fiery scarlet wilh orange shading; lower segments striped violetbrown; finest of all reds. Eack, 20c; dozen, \$2.00.

ILLLAN WEBB-Strawberry pinls with light maroon velvety center; sometimes slightly striper with chocolate; stems slender, giving the appearance of a lily; flowers 5 inches in diameter, spikes 5 feet high. Each, 10c.

*LILY LEHJA $x$-A pure glistening white with just the faintest tinting of pink on tips of the petals. Each, 15e; dozen, \$1.50; hundred, \$10.00.

LILYWHITE-A reliable first-class early all-white variety. Each, 50c; dozen, \$5.00.

*L'IMIMACULEE-Undoubtedly the best commercial white Glad in existence. Each, 10c; dozen, \$1.00; hundred, 57.00 .

LILLIAX HARRIS COFFIN-Light rose pink, salmon striped, very fine flower. Each, \$1.00.

* LoUISE-Clear pure lavender of a bluish tinge: has no magenta or purple in it, and this makes it the firiest lavender yet produced, nearly the same shade as Iris Pallida Dalmatica, which is enough said. Each, \$1.00; dozen, \$10.00.

LOVELINESS-The color is of pale creamy tone, soft and delicate, with a roseate tinge in the center. Each, 10c; dozen, \$1.00; hundred, \$7.00.

L'UNIQUE - Bronze, with orange yellow center. Flowers medium size, but very early and continuous. 15 e each; $\$ 1.50$ per dozen.

MADAME NONNET SLLLY-Cream-white with red center. Each, 50c.

IAINE-Its color is pure white; not the faintest spot or blemish can be traced on petals, throat, or the inside of flower. Each, \$2.50.

*MAJESTIC-Here is an orange shade that is new. It is not the orange of Alice Tiplady. This is wonderful, but a shade that has a tinge of salmon in it. Each, 60c; dozen, $\$ 5.00$.

IARIN-Pale greenish yellow, a fine cut flower rariety. Each, 25e.

IARY FENNELL-Beautiful light lavender flowers on a tall, slender spike, lower petals primroseyellow with penciling of lavender. Each, 20c: dozen, \$2.00; hundred, \$12.00.

MARY PICKFORD-Color a delicate creamy-white, throat soft yellow. Each, 50c; dozen, \$5.00.

MASTER WEITSE-Rich deep dark velvety purple. Each, $7 \mathrm{e}$; dozen, $75 \mathrm{c}$; hundred, $\$ 5.00$.

* MAY - White, heavily striped and splashed pini. Each, 6e; dozen, 60e; hundred. \$1.00.

IEAD OWVILLE- White with lilac throat, a very pretty white flowering Gladiolus. Each, 6c; dozen, 60e; hundred, $\$ 4.00$.

IINNESOTA - Creamy white, red blotch, early. Each, 10c.

MISS CHRISTINA TRECER (New)-It gives a soft rose colored flower without stripes or blotches. Each, \$2.00.

IISS LUCILLE-Shell-pink, shaded larender. Each, 10 cents; dozen, $\$ 1.00$.

- MISS MACD FAY - Clean Cattleva-pink, a light stripe running through the middle of each petal. Each, \$2.00.

MR. H. A. HYDE - White, faint tintings of pink, flower 6 inches in diameter. Very fine for cut flowers. Each, 25e.

MR. IARK-This variety is a charming blue color that does not wilt in the brightest sunlight. Each, 25e; dozen, \$2.50.

IRS. COTHR AX-Crushed stramberry and ashes of roses; very odd color; fine long spikes; flowers 6 inches in diameter, spikes 4 to 5 feet long. Each, 25c.

Ims. DR. NoRTON-Color, white, the edges suffused with soft La France pink. The three lower petals have a blotch of sulphur-vellow. stained at the base with ñne specks of Tyrian-pink. Each, \$1.00: dozen, \$10.00.

IRS. FRAXCES IIXG- A.most" beautiful "Besnard shade" of flame-pink: Each, 5c; dozen; 50e; hundred, \$3.50. 


\section{GLADIOLI-Continued}

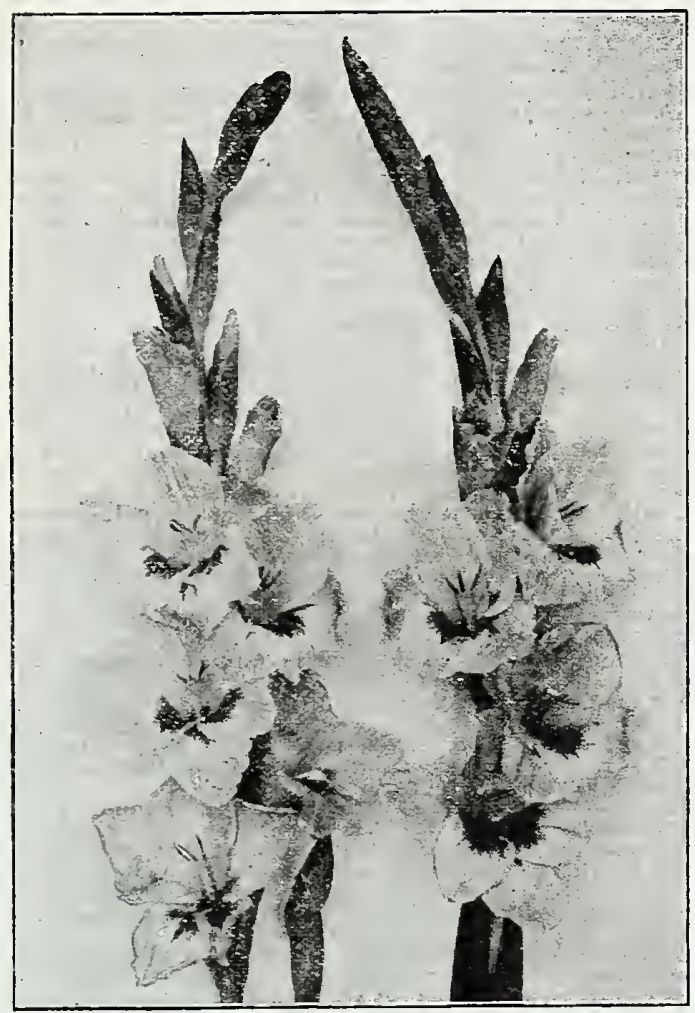

Mrs. H. E. Bothin.

yIS. H. F. BOTHIN - Flesh-salmon pink, flame scarlet center, strong 4 to 5 foot spikes; a first class show variety. One of the loveliest color combinations in Glads. Each, 26e.

HRS. FRANK PENDLETON - The petals show beautiful bright rose-pink on a pure-white cround, contrasting in a most striking way with the deep rich velvety blood-red blotch on the lower petals. Each, 10c; dozen, \$1.00; hundred, \$7. HRS. JAMES K. ARMSBY-Coral pink, with creamy yellow throat. Each, 25 cents.

\%IRS. JAMES LA NCASHIRE-A deep cream fading to a rose tinted flesh color, with contrasting stripe of carmine on lower petals. Each, 3te; dozen, $\$$ \$.5.50.

MIR. JoHN R. WALSH-Flesh pink with flame colored center, very fine flower with a very tall spike, one of the finest flowers grown. Each, 25c.

MRS. LILLIAN GUERNSEY-Yellow, pink blotched, good flowers, very fine spike. Each, 25e.

IRS. LEON DOUGLAS-Flesh salmon pink, orange strip dotted with brown spots in center, the largest fine Gladiolus grown. Each, 25e.

IRS. MARY STEARNS BUTK-Can a $\mathrm{r}$ y-yellow overlaid with apricot: deep canary center; long spike with flowers symmetrically placed; stem wiry and upright; flowers four to five inches in diameter, spikes four to five feet high. It is one of the finest yellow's known so far. When known it will be one of the most grown varieties for eut flowers. Wach, 50e.

MRS. RTDOLPH SPRECKC.ES-Cream pink with old rose stripes; fine, long, full spikes. Wach, 50c. MRS. VELTIUYS (New)-Dark brilliant red, large flower. Wach, 30 cents; dozen, \$3.00.

*MRs. WATT-Glowing American Beauty shade of wine-red; self color. Each, 15e; dozen, \$1.50; hund red, $\$ 10.00$.

MRS. W. E. FRYER-Lincoln-red, almost without markings. Deep in throat, some crimson lines alternating with white. Each, 35e; dozen, \$3.50; hundred, \$25.00.

MIRS. WILIAIRD RICHARDSON - D e e p crimson, maroon center; large, flaring flowers; flowers five inches in diameter, spikes four and five feet high. An unexcelled red which does not fade. Eneh, ove.

*MIRS. WILLIAM KENT-Light fawn to light ashes of roses; old rose in throat, sometimes lightly striped with rose-pink. Each, ate; dozen, \$2.50.

* IURIEL-The most delicate shaded gravish-blue Each, \$1.00; doxen, \$10.00.

*MYRTLE-The most beautiful pink yet produced in a Gladiolus. Clearest dainty ruffled rose-pink, softly dissolving into a throat of clear creamywhite. Eneh, 15e; dozen, \$1.50.

MYRTLE MeNALLY-Cream with touches of rose spike on each, ruby center, clear yellow lip, heavily ruffled, vigorous growth. Ench, 25c.

NEGERFURST-Brilliant velvet y blood-red, flaked with black, inflamed with white and flaked lilacrose. Wach, 25e; dozen, \$2.50.

NEZINSCOTT (Ch. Childs) - Bright blood-scarlet, with deep velvety, crimson-black blotches and white mottlings. Each, 10c.

* IIfARA - A light Crocus or Primrose-yellow faintly touched with lilac-rose lines; faintly suffused lilac-rose by reflection from outer. walls of petals. Each, ic; dozen, $70 \mathrm{e}$; husd red, 55.00 .

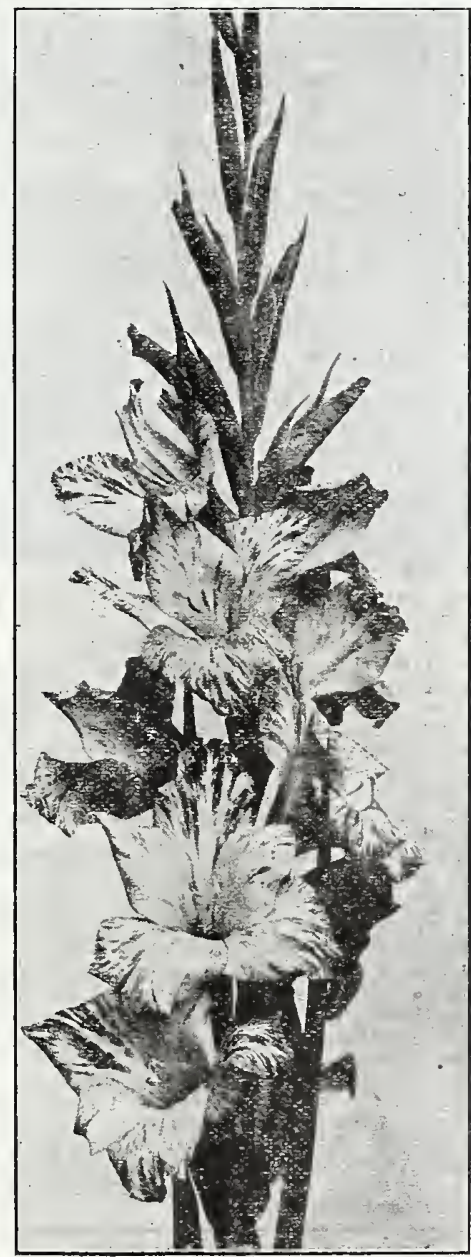

Norma Krausgrill.

YOHMA KRAUSGRILI-Light, rose pink with deeper stripe, throat canary-yellow, large flowers. Each, \$5.00.

ORION-Light rose with dark blotch: a superb variety. Each, Ge; dozen, 60e; hundred, $\$ 4.50$.

PASADENA - Turkish-red, flame orange striped, white lip; flowers 7 to 8 inches in diameter, spikes six feet high. First-class show variety. Each, 25e. 


\section{GLADIOLI-Concluded}

PEACH ROSE (1917)-An extra choice and distinct deep rose-pink of remarkable color and appearance. A very beautiful variety. Each, $75 c$; dozen, $\$ .50$.

PRINCEPINE (Kirchoff)-One of the most brilliant scarlet reds, It is a very vigorous grower; well open, large and fine substance. The throat is glistening white. Award of Merit, Haarlem and London. Each, is cents; dozen, \$1.50.

PROPETESSE-Ivory-white with crimson bloteh on lower petals. Each, 10c.

* PA NAMA-A perfect Hermosa-pink in color with wide open wax-like flowers; one of the best of the clear pinks. Each, 7c; dozen, 75e; hundred, \$5.00. * PEACE-Giant white flowers with lilac feathering in throat of two of the petals. Each, $7 \mathrm{e}$; dozen, 75c; hundred, \$5.00.

* PINK HEAUTY-Pale carmine-lake, three lower petals forming rather large Geranium-red blotch. Each, 10c; dozen, \$1.00; hnndred, \$7.00.

*PINK PEIRECTION-A true apple-blossom pink with immense flowers. Each, 15e: dozen, \$1.50; hnndred, $\$ 12.00$.

* PIIDE OF GOshex (Ruffled)-Pale flesh, tinted very delicately Rose Eglantine with a golden sheen; throat washed faintly with yellow-buff. Lower petals broad stripe of cochineal-carmine, and a few delicate pencilings of the same color. Each, 20c; dozen, \$2.00.

*PRINCE OF WALES-Golden-salmon melting to throat of primrose-yellow, a color tone that either in sunlight or under electricity is extreme$\$ 20.00$.

PRINCEPS (Known as the Thonsand Dollar Gladiolus) - Large Amaryllis-like flowers of a rich dark sciarlet, with deep shadings in throat and magnificent large white blotches on

PURPLE GLORY (Ruffled)-Beautiful rich ruby-red with blotches of reddish-black. Each, \$2.50.

*QUEET OF WHITES-Very large, glistening pure white flowers. Each, 7c; dozen, $75 c$; hundred, \$5.

QUEFN WILHEIMINA - Delicate apple-blossom pink with pale blotches on lower petals. Each, $7 \mathrm{c}$; lozcn, $75 \mathrm{c}$; hundred, $\$ 5.00$.

IRD EMPEROR (Syn. Dominion)-A giant in size. Regal is the only word which adequately describes this Gladiolus A pure deep scarlet or blood-red; immense flower of great substance, well placed upon a tall spike. A magnificent flower. Each, $25 e ;$ dozen, $\$ 3.00$.

REVEREND EWHANK (New)-Light lilac, a glorius light blue Gladiolus, said to be the best of all the blues. Each, 75e; dozen, \$S.00.

RICHARD DIENER (Diener)-Pure rose-salmon, light sprinkling of ruby on creamy-yellow center. This is the acme of perfection in coloring, as well as formation of spike and plant. Will rival an Orchid in beauty. Flowers six inches in diameter, spikes five to six feet high. Created a sensation whenever shown, as Champe, the Gladio-"
lus expert, says: "The finest pink in the world." Each, s10.00.

ROSS VALLEY-Salmon-pink, striped with ashes of roses, red peacock eye. Each, $25 c$

1910 ROSE (Kunderd)-Pure rose pink of extra fine shade. Narrow white central line on lower petals. Very large flowers. Early. Each, 25c.

ROSE WELLS-Large wide open flowers; clear pale rose with small attractive blotch of lilac-rose touched yellow. Spike similar and nearly as tall as Evelyn Kirtland. A worthy variety in every way. Each, 50e.

OSELLA - Delicate rose-mauve, stained purple white. Each, 15e; domen, \$1.50.

* ROUGE TORCII-Large creamy-white flower with scarlet feather in lower petals, much like a rouge, torchlike tongue, making a striking contrast. Each, 15e; dozen, $\$ 1.50$
SAN ANSELIIO-Pure white, slightly striped with pink, large flowers. Each, 25c.

SACSOLITO-Rose pink, overlaid with salmon, ruby throat. Each, 25e.

SCARSDALE-A deep. Jacinthe, shading to lavender-iris with rose tintings. Each, 10e; dozen, \$1. SCARLANO-Deep scarlet, bright orange red, very fine flower, heavily ruffled. Each, 25c.

* SCHWA BEV - A clear citron-yellow with Aster purple tongue on lower petals. Buds sulphuryellow. Each, 10c; dozen, \$1.00; hnndred, \$7.00.

SCRIBL-Tinted white, streaked and variegated fine crimson; sometimes varied with white; frequently these beautiful variations will show in the same spike. Each, 25e.

SIR ROGER CASEMENT-Dark maroon, heavily ruffled; fine long spikes; flowers four inches in diameter; spikes four to five feet high. Each, 25c.

SUFFRAGETTE- White with circle of light lilac running across each petal, creamy white throat, flowers seven inches in diameter. Each, 25c.

SULPHUR KING-It produces a rery long spike of the clearest sulphur-yellow flowers yet seen in any Gladiolus. Each, 25e; dozen, \$2.50.

SUNBEA I (Prinulinus)-Color a rich self-yellow no other markings. Light and graceful. Each, 15e; dozen, \$1.50: hundred, \$12.00.

SUNSET-Pale flesh pink overlaid and striped with rose pink, a fine flower. Each, 25c.

TACONIC-Bright pink, flecked and striped with a delicate pink; lower petals blotched a deep crimson, edged with a thin yellow stripe. Each, 6c; dozen, 60e; hundred, \$4.50.

TAMALPAIS - Salmon-orange, with flame orange tripes, slender spiked, very fine flower. Each, 25c.

THOMAS T.KENT-Rose-pink with ruby running through the center of each petal. Each, 25t; dozen, \$2.50.

TITANIC-Very large dark magenta. Each 25e.

VICTORY-D a inty yellow with lower petals a deeper tone. Each, fe: dozen, 60e; hundred, \$4.50 VOLET PERFECTION - A deep, rich Dahlia-purple. A self-color, very large, open flowers with no markings. A magnificent novelty and the gem of its color section. Each, 25c.

WA IBA-Light strawberry pink with rose throat markings. A most unusual Gladiolus, because of the immense blooms with petals of an orchid, and with lily-like buds. Each, 25e.

WAR-Deep blood-red, shaded crimson-black; very tall and conspicuous. Each, 15e; dozen, \$1.50; liundred, $\$ 10.00$.

*WHITE AYERICA-This is Child's new white that he says are "The flowers that open uncut in the light and air are whiter than any commercial white variety grown." Each, 35e; dozen, \$3.50.

*WHITE EXCELSIOR - A very fine large-flowered white of the "American" type: clear throat. Each. fe: dozen, 60c; hundred, \$4.50.

WHITE GIANT-A white, pure as the driven snow. The edges of the petals gracefully ruffled. Each, soc: dozen, Ss,o0.

WHITE LADI-Pure white without markings, even the anthers are white. Each, 50c; dozen, \$5.00.

*WILBRI ICK-Flesh-pink with creamy blotch on lower petals. Each, 10c; doz., \$1.00; hundred, \$.00. WILD ROSE-Color of the wild rose, large flower. Each, 50c; dozen, \$5.00.

WILLIAM FALCOXER-Beautiful clear light pink. Large. Each, 25c.

WILLIA M KENT (Ruffled) - Creamy shell-pink. golden ochre center, heavily ruffled. Each, \$10.00. * WLLT WIGMAN (Blushing Bride) - Blush tint with long bright red Tulip blotch on lower petal: spike of graceful habit, and the effect of the crimson on the cream petal is most pleasing. Each, loc: dozen, \$1.00; hundred, st.00.

YELLOW HAMIIER-P ure yellow. Each, 15 cents; dozen. \$1.50; hundred, \$12.00.

YOUELL'S FAVORITE-Coloring is very beautiful, a mingling of carmine-rose and cream. Strongly flushed and marbled with cochineal-carmine; creamy middle band softly blended. Here and there over the flowers is a flash of pale old gold. Each, 25c; dozen, \$2.50.

\section{MixedPrimulinusHybrids}

These hybrids, gained by crossing the species Primulinus with the larger varieties of the Gandarensis type, have retained all the daintiness and graceful form of their Primulinus parent. even to the "hood" formed by the drooping of the upper petal, and have an added beauty of exquisite coloring, from the softest primrose to a beautiful rose. Each, 10c; dozen, $\$ 1.00$; hundred, \$6.00.

\section{Gladioli in Mixture}

Persons who do not plant mixtures-no matter how many of the named kinds they plant will miss much of the pleasure of this grand flower. In colors every magnificent and gorgeous combination conceivable is represented. The richest of self-colors, blotched, etc.; the finest white and pastels of every tint and color. Each, 5e; dozen, 50e: hnndred, \$3.50; thousand, \$30.00. 


\section{CARNATONS THE DIVINE FLOWER PINKS}

For beauty of flower and color, ease of culture, certaintr and freedom of bloom, together with exquisite fraglance, this is well called the "Divine Flower." Plants in the open ground or in pots quickly make large specimens, and when blought indoors in the fall produce an abundance of flowers throughout the entire winter. Carnation blooms are expensire; don't buy them-grow them yourself. Pinch the pot, keep in a temperature of forty or fifty degrees at night, and they will yield an immense number of nowers with splendid stems, as fine as those sold or forists. If not pinched in they will bloom profusecyuring the

\section{Excelsior Collection of Choice Carnations}

20 cents cach; set of Three Excelsior Carnations, postpaid, for 50 certs, the entire Gight for \$1.2.5.

IHEXORA-The ground color is the faintest blush, lightly penciled in soft pink. The bloom is fuffy in appearance, exquisitely beautiful in form. One of the grandest of all Carnations.

CIAMPION-This is by far the darkest Carnation ever seen, and at the same time the most abundant bloomer. Brilliant dark led, sliaded with richest maroon, fringed petals, nearly every flower being on a long stem. This variety surpasses in lichness of color the most perfect Jacqueminot Roses.

CLORIOSA - This variety has been greatly admired wherever it has been seen for its desirable color, being a beautiful light pink satin color; flowers large size and very freely produced. Plant of grand habit and vigorous growth. It is a superb rariety.

GOQD CHEFif-One of the most fragrant Carnations we have seen. Color a clear, bright, glowing scarlet; a most coritinuous bloomer and distinct in color from any other sort offered. Greatly admired by all who have seen it growing here.

MERALD-One of the grandest of all Carnations for the garden, a dazzling red color that nothing surpasse

MATCIILES-Largest flowers of the purest immaculate white; large sized-blooms. Valuable for garden planting and for pot culture. Tery sweetly scented with that delightful old-fashioned clove fraprance.

ROSETTE-No other Carnation we know of equals this fine dark rose colored variety; very fragrant. SHNSATION-Celtainly a grand pink Carnation of the largest size and deliciousiy scented.

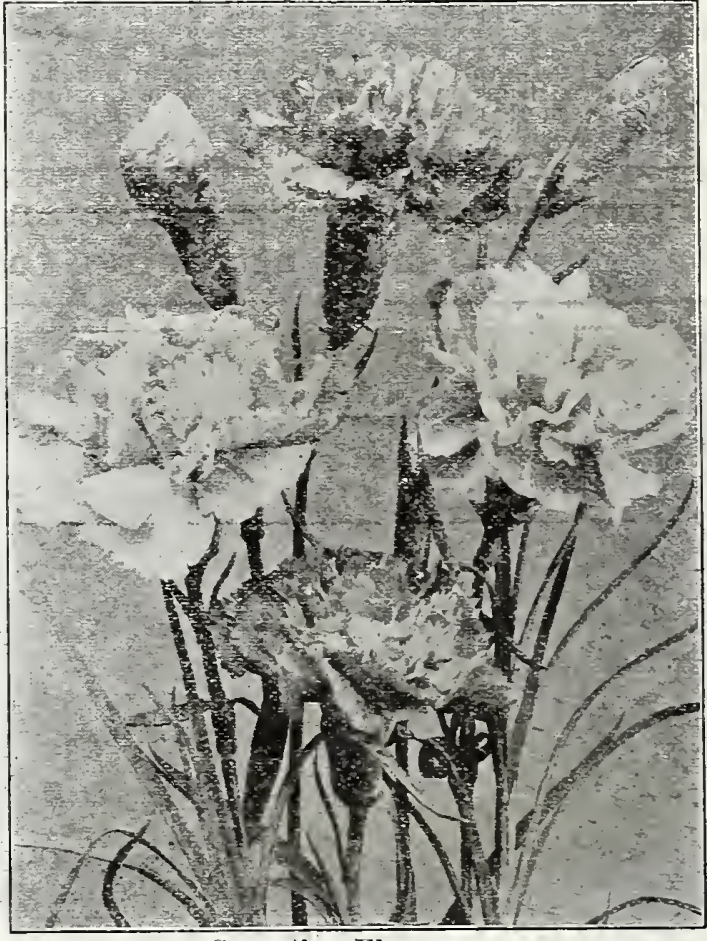

Carnation Flowers.

\section{Set of PRIZE-WINNING CHRYSANTHEMUMS}

The following varieties are the cream of all the "Mums" to date. Price, 20 e each, excent where noted.

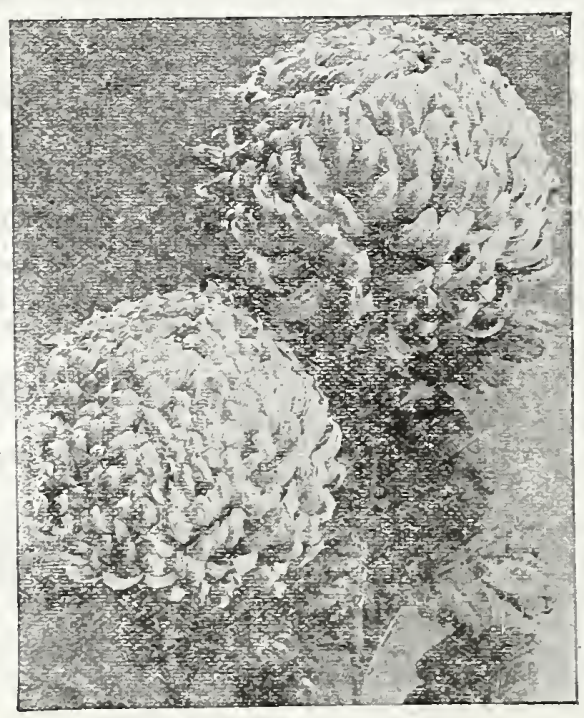

"Hum" Golden Werlding.

SPEQTAL OFEER Any six priced at 29 cents for nins" Set of Thirty-nine Choicest Varieties, costing $\$ 8.55$ for $\$ 5.55$.

HLACK H HW-An extra fine deep crimson rariety of the largest size; none funer of its colol.

BIONZE BEAUTY-Beautiful bronze color; rererse yellow.

HCCKBEE-A fine snow-white.

CANARY BIRD-Rich golden-yellow: extra.

CHARHAS RAGER-Pure white, incurted. Perfect flower.

CHIFFri -The most popular pink; good in every CHIJ Solor - The best yellow for eavly october CLENENTINE TOUSET-The most wonderful of ali white "Mums." Pure snow-white, often flushed pink: of immense size.

COLONEL D. APILFTON-One of the best yellows for commercial and exhibition use.

DOLLX DIMPLE-A fine large built varietz. Extra. TR. ENGUEHARI-Bright rose-pinli; extra fine. GoLDEN EAGLE Tery intense sellow, wide petals incurved form, one of the finest.

GOIDEY GLOW-Bright yellow, good stem and foGOLDEN OUEEN - The best yellow variety for early October. None better. is cents. GOLDEN ISDDING-Nothing finer among yellows : shines like burnished gold. The standard fol IIIJARI-Japaese reflexed, very dark crimson; 


\section{Set of Prize-Winning Chrysanthemums-Concluded}

L'AFIbICANE-Thought by many to be the best red "Mum."

LOUIS BOEHMER (Ostrich Plune)-A most beautiful shade of lavender-pink.

MAJOR BONNAFFON-One of the very best deep golden-yellow Chrysanthemums; beautiful fower, both in form and color; incurved.

MARTGOLD - As a golden-yellow is unsurpassed both as to size and color. A monster flower. 25 cents.

MAUD DEAN-The old standby pink; hard to beat. MHLLICEN' RICHARDSON-A glorious red flowering" "Mum;" large bloom.

MISS FLORENCE PTLLMAN-Many think this superi white cannot be beaten.

MLSS HINNIE BAIELY-One of the grandest all pink Chrysanthemums. In finish it is exquisite, showing not the slightest trace of coarseness.

MHSTLTOE-Blush-white; late flowering.

MRS. EDWARD SEIDRWITZ-A very late variety of beautiful incurving form, quite full, brilliant pink, good enough to follow Chieftain, which is saying a good deal for it; it is a nice grower.
MFS. HMNRY MORINSON-Incurved white; a splendid variety.

oCoN'T-Large white blooms; on strong stems.

PACLIC SUPREME-This grand variety has literally leaped into populaxity. Flowers al e so large as to startle you. The color shades from lavender-pearl to the richest pink.

P.1TE-Very delicate shade of pink.

IEIO DE ITALIA - Flower's of mammoth size anc. deep golden-yellow; really a wolder.

ROIEHE' F. MAldDAY-This is a glorious flower, of burnished yellow.

MOMAN GoLD - Very intense yellow, showing bronzy tints in the depths of the petals, hence the name.

SILVER WWDDENG - White with a slight pink tinge, ball shaped; extra n̂ne.

TINTS OF GOLD-Has the coloring of a beautiful golden sunset.

NAKA-A fine incurved bloom of a pleasing shade of pink.

WIITE BONN FON-Incurved white;-still largely grown for its many good qualities.

WMTES CHIEFTIN-Beautiful incurving white.

\section{Hardy Large-Flowering Chrysanthemums}

The majority of Chrysanthemums are hardy south of the Onio river and many are hardy in the Northern states, as far as the plant is concerned, but they must flower before early frosts to be of service. The varieties offered below generally flower from the last of August to the fifteenth of Oetober.

Price, 20 cents each; three for 30 cents; the set of seven for $\$ 1.00$.

AUNT MARY-Fiery terra cotta or rosy-crimson.

INFIAT-A fine shade of Indian-red.

WXCLSIOR-Rich fine yellow.

GIORY OF SEVEX OAKS (Carrie) - Deep golden

yellow; a beauty.

IACK TROST-Snow-white; very free flowering.

OLD LAVENDER-A beautiful shade of lavender.

SUNGLINE-Bronzy-yellow; large fiower.

\section{Early Large-Flowering Chrysanthemums}

So many persons have asked for varieties of Chrysanthemums that would fiower before frost comes in the fall. We here offer the very best early "Mums," so you can see them fiower in the garden. I'riee, an cents etich; the six for $\$ 1.00$.

ADVANCE-The earliest flowering large white; has been had in bloom in July.

EARLY SNOW-The earliest of all white "Mums." Superb.

ESTELLE (or Polly Rose)-Pure snow-white; literally cover's the plant.

GLORY OF THE PACIFIC-A lovely s ha $d$ e of brightest pink; large and fine.

oCTOBRr Frost-Purest snow-white; fairly glistens in its purity.

YELLOW ADV $\triangle$ NCE-By far the best; very early yellow, rich and fine.

\section{Hardy Pompon Chrysanthemums}

These beautiful varieties are again very popular for outdoor bedding purposes. They are quite hardy and with but a slight covering of leaves or coarse stable litter during the winter will take care of then selves after once planted, and produce an abundant, almost lavish, profusion of bloom; and the plants lend a coloration to the garden just at a time when other plants have been destroyed by frost and are looking their worst. Frost does not materially affect the fiowering, and it will frequently happen that an armful of flowers can be cut after a sharp frost.

Price, 20 cents each; any three for 20 cents; the set of eleven for $\$ 1.75$.

BABY-Deep golden-yellow; covers the plant.

DIANA-Snow-white; very free.

FinAK WILCox-The very best bronze shading to

GolDer CLIMAX-Orange-yellow. The best yel-

low in cultivation.
IXDLAN PED-Coppermed. Shaded with crimson. LILLIA DOTY-Flowers beautiful shell-pink. RED EUTWON-Old rose color.

IRHODA-Rosy-lake or red.

SNOWDROP-A beautiful white.

WESTERS BEAUT-Rosy-pink; extra.

\section{Spring is the Proper Time to. Plant Chrysanthemums for Fall Blooming.}




\section{OUR GRAND GARDEN DAHLIAS}

No garden is complete without a show of these brilliant and stately autumn flowers, and nothing gives greater return for so little money and care. We offer dry bulbs or tubers, but if stock of these becomes exhausted, will send started plants. We grow and seli fifteen acres of Dahlias each year.

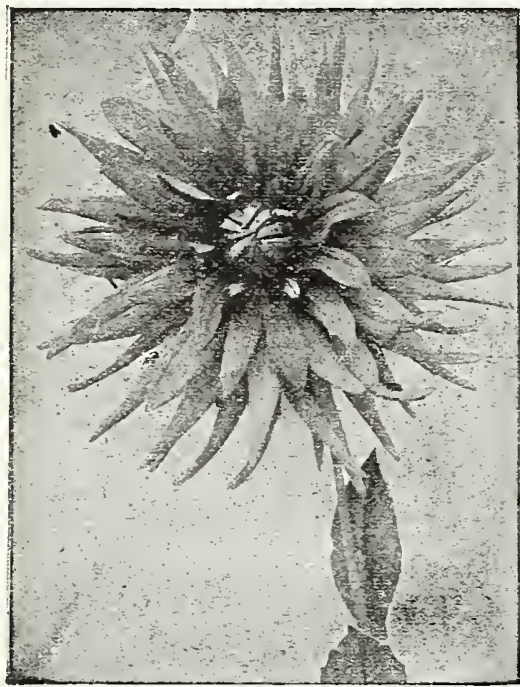

Dahlia Countess of Lonsdale.

FLORA-The ideal white for cut flowers. Pure color and extremely free blooming.

FLORADORA - Deep dark, rich wine-crimsonsplendid shaped flowers on long, upright wiry stems.

J. II. JACKSON-This is without doubt the finest dark Cactus Dahlia. Its velvety black crimsonmaroon shade is very striking. Large and perfect.

IXALIF-(New.) The best red Cactus to date. O. K. in every way. A wonder. 50 cents.

KRIEMHILDE-A most popular cut flower variety. Color a brilliant pink, shading to white in the center.

MARY SERVICE-Bright salmon, edged and overlaid lilac, an improved Countess of Lonsdale.

PRINCE OF YELLows-One of the best canaryyellows for cutting.

\section{Cactus Dahlias}

Shom their resemblance to Cactus flowers. They are of graded lengths, giving the flowers a striking and attractive pearance. Grand for cut flowers.

noted, 30c each, three for $75 c$. The entire set of 16 Cactus Dahlias, costing \$5.20, for $\$ 4.50$.

AMOS PERRY-The best bright scarlet Cactus to date. Color purest flaming scarlet, with long, narrow, twisted petals of age in the utmost profusion. Certainly a beauty.

URORA - Very free flowering; reddish-apricot, suffused with

HARLES CLAYTON-The strongest words of praise are not exideal ant when applied to this wonderful new Cactus. It is the yond which it would seem little could be hoped for. The color

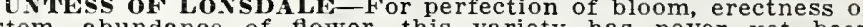
equaled. On several of the plants we have counted over 150

QUEEN OF HEARTS-(New.) The best white Cactus ever introduced. Pure white shading to lemon-yellow at base of the petals; very free bloomer.

REINE CAYEAUX-Brilliant Geranium-red; early and free; a great favorite.

RUTH FoRBES (Hybrid.) The massive, clear pink flowers, composed of heavy petals, are often accompanied by stems measuring 2 feet in length: excel any other variety for large vase purposes.

SPRINGFIELD-A new Dahlia of our own introduction. It is identical with Countess of Lonsdale except in two essentials. It has a darker stem and the flowers, instead of being a salmon-pink as in Lonsdale, in Springfield are a rich amaranthine-red. Its beauty cannot be described. No Dahlia blooms freer, no Dahlia is as pretty as Springfield. It lasts longer cut than any Dahlia we know.

\section{Decorative Dahlias}

These come next to the Cactus as a cut flower. Are also very showy in the garden, being unusually free bloomers. Are more formal in make-up than the Cactus Dahlias, but not so formal as the show varieties - a hapy medium between the two.

Except where noted, 30c ieach; three for $75 \mathrm{c}$. The entire set of 20 Decorarive Dahlias, costing \$6.50, for \$5.60.

AVALANCHE-Very large and beautiful, plants of clear white BLACK BEAUTY - Deep velvety maroon. The blackest of all Dahlias. BASE'T-Color bright royal purple, shading to lavFRANK L. BASSET-

HORTULANUS FIET-(New.) Salmon-pink, yellowish center: as large as Souv. de G. Doazon. Has taken many first prizes. 60c. ACK RosE-Magnificent flower with perfect form. Color rich crimson-red with maroon shadings. Named for its counterpart among roses, the famous "General Jack."

JEANNE CHARMET-A charming cut flower variety of a pleasing shade of delicate violet-rose on a lighter ground. A glorious flower.

IING OF THE AUTUMN-One of the finest decorative Dahlias ever introduced. The habit is absolutely perfect, with strong, sturdy stalks; long, stiff stems and remarkably free-flowering. The coloring is something quite new and unique, buff yellow suffused terra cotta. Obtaining several first-class certificates in Holland, this Dahlia is destined to become one of the most popular varieties ever introduced.

MADAME A. LUMIERE-Ground color white, suffused towards ends of petals with red, tips pointed with bright violet-red.

MATCHLESS-Deep crimson, of large size; an early and late bloomer. This we consider one of the

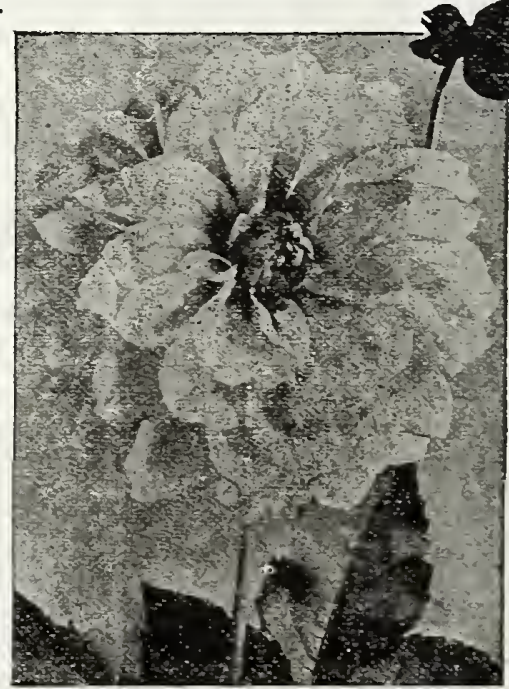

Dahlia Irs. Charles Seybold.

MELODY - One of the finest, being of splendid regular form with full high center and reflexed outer petals. Color clear canary-yellow, tinting to creamy-white at the tips; an effect so delicate and pleasing as to sugrest. the name. 50 cents. 


\section{Decorative Dahlias-Concluded}

MINOS-One of the finest Dahlias to date. Flowers are large and exceedingly beautiful, borne on long, graceful, wiry stems. The color is intense velvety maroon, almost black. An ideal cut-flower variety. Fine for all uses.

MINA IURGLE-(New.) Best scarlet-red Decorative Dahlia ever introduced. This wonderful Dahlia is a California introduction and is the best of its color. The form is perfect decorative type, petals being broad and flat; has a perfectly full center and is a Dahlia that can be grown to an immense size with ordinary treatment. It was very prominent at the Panama-Pacific International Exposition where it was grown in masses around the Horticultural building. It shows finely under artificial light and for cutting purposes is unsurpassed. We were fortunate in securing a stock of this variety, and can highly recommend it to our customers.

IRS. J. GARDVEI CASSATT-A new rose-pink Dahlia that has attracted a great attention. The flowers are of immense size. Said by many to be the finest of all deep pink Dahlias.

MRS. CHAILWS SEIBOLD-One of the freest flowering of all Dahlias. A Cadmium-red, an intermingling of red and orange. Very show

PAIA CHARUE'r-Bright, glowing velvety maroon. PRINCESS MARi-Light pink with lavender sheen; exceptionally fine form and habit for cutting and will come up to the claims of Holland originator as the best of the pink. Holland Dahlias for flor ists' use.

QUEEN IARY-This is a stronger grower than Delice. A large flower with full, rounded center. The color is a soft shade of pink.

SOUVENIR DE GUSTAVE DOAZON-This is the largest of all Dahlias. A lovely shade of orangered. A veritable giant among flowers.

WILIIAM AGNEIV - Intense glistening crimsonscarlet, of large size, and gracefully recurving form. The most popular standard red.

zULU-The blackest of all Dahlias.

\section{Show and Fancy Dahlias}

These are the old-fashioned Dahlias of our mother's gardens. Perfect in shape and outline. Except where noted, 30 cenis each, three for 75 cents. The entire set of eleven Show or Faney Dahlias, costing $\$ 3.50$, for $\$ 3.00$.

ARABELLA-Primrose-yellow, tipped and shaded old rose and lavender; very fine.

CUBAN GIANT-Flowers of great size, measuring six inches across. Color dark, glowing crimson, shaded maroon. Magnificent.

DELICE-Its beautiful soft yet lively color a glowing rose-pink together with its shape, makes it one of the prettiest and most valuable of all Dahlias

GRAND DUIE ALEXIS-This is one of the most delicately beautiful of all Dahlias. Very large, perfect form, with long. thick quilled petals overlapping at the ends. White slightly tinged and suffused delicate lavender. Ethereally beautiful. 50 cents.

LUCY FAWCETT-Sulphur-yellow, striped and spotted carmine-rose.

QUEEN VICTORIA-Pure canary-yellow. One of the freest bloomers. Good for cutting.

RED HUSSAI-Pure cardinal-red; fine.

ROBERT BIOOMHIELD-Pure snow-white. Of large size. A very free bloomer. Grand fol cut flowers. We recommend this variety.

VIVIAN-Color white, effectively edged rose-violet. An ex tremely wonderful blending of color possessed only by the rare novelties. A variety worthy of the highest praise.

SYLVIA (or Dolly)-Flowers four to six inches in diameter; of fine form and full to the center, which is white, shaded to sof pink on the outer petals. In freedoin of bloom next to th Countess of Lonsdale. A magnificent Dahlia.

W. W. IA IVSON-Very large with semi-quilled petals, long upright stems, color white, delicately flushed and suffused lilac. G0 cents.

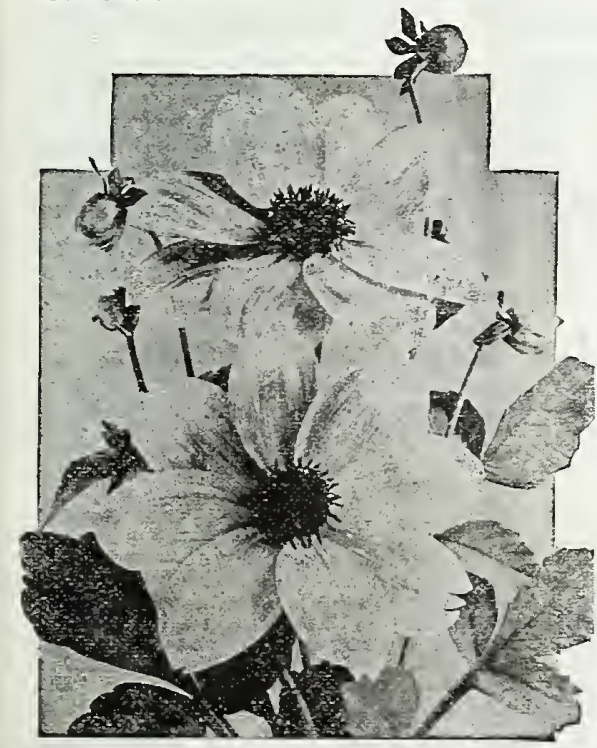

Century Dahlias.

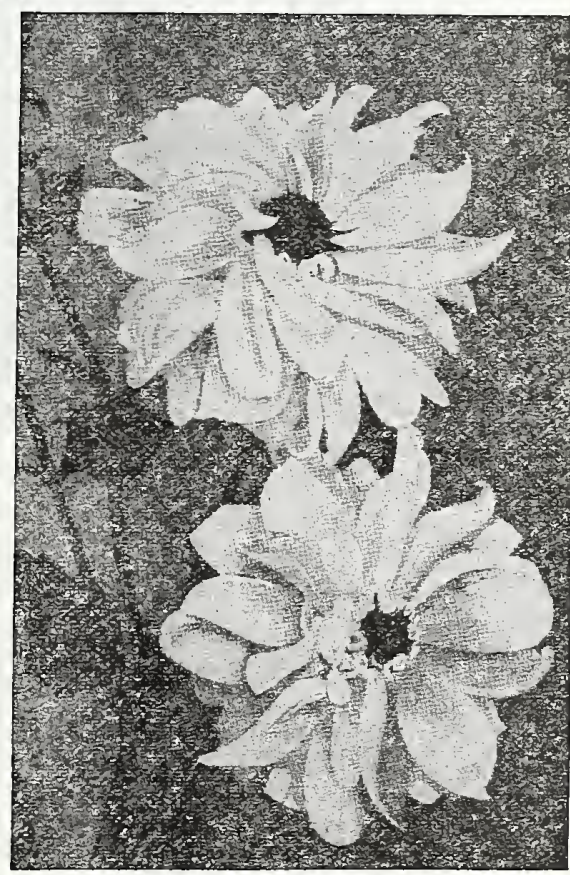

Dahlia Geisha.

\section{Century Dahlias}

This is an entirely new race of Single Dahlias. We consider today that the new Century Dahlias occupy first place where beauty of coloring and artistic effect is desired. Owing to their immense size, long stems, graceful carriage, combined with their purity of color, or the blendings of colors, shades and tints, they entirely outclass all other Dahlias for cut flowers. Keep each variety when cut in a separate vase. Price, 30 cents each; four Century Dahlias, costing $\$ 1.20$, for 75 cents.

BIG CHIEF- Rich crimson with maroon shadings on margin. CRIMSON CEN'TURY-Deep, rich velvety crimson, shaded maroom, with rose halo around yellow disc.

FFINGLD CENTURY-Intense rosy-carmine with lighter edges, fringed or cleft petals; blooms all summer; fine for cutting.

ARIAGATED CENTUIRY-This, next to Geisha, is the gayest of all Dahlias. Dark oriental red with yellow tips and markings. A superior variety. Very showy.

\section{Peony Flowered Dahlias}

\section{A new family of Dahlias originating in Holland. The artistic} flowers are very large and are best compared with the semidouble Peonies in form. The gayest of all Dahlias for coloring. The entire set of seven Pcony-Flowercd Dahlias, costing \$5.50, for $\$ 5.00$.

CHATENA Y - Its beautiful salmon tints form a perfect contrast with the deep green foliage. Strong, sturdy, upright growth and produces its blossoms erect upon good long, stiff stems. The beautiful golden-yellow center completes the artistically arranged gem and lends an additional charm to this new acquisition. \$1.00 eacl. 


\section{Peony Flowered Dahlias-Concluded}

DR. PEART-Gigantic Holland Peony-flowered Dailha. Without exception the very finest dark Peony-flowered Dahlia in existence. A rich, relvety wine-crimson or dark mahogany. Flowers of gigantic size and identical in form and shape to the "Geisha." \$1.00 each.

GEISHA (Peony)-Gold and scarlet, striped and shaded. Tery showy and always attracting much attention because of the striking color mixture stained and striped throughout the twisted, curled petals. "The showiest and most attractive of this type" of Dahiia. "5 cents each.

JOHN WANAMARR (Peony) - Violet-mauve or soft lavender. The originator says, "this Dahlia is not only large but of extremely delicate tcxture and artistic formation. 50 cents each.

QUEEN THELELIINA - Giant Holland Peonsforrered Dailia. Largest and fincst of the pure white sorts; excellent for decorative work and upon long. graceful stems, Fell above the foliage.
An immense, fluffy flower of pure glistening white, showing its beautiful golden-vellow center very prominently, which lends an additional charm to this most beautiful flower. 75 cents each.

SHERLOCK HOLAES-Beautiful Holland Pcony110 wered Bahlias. An ideal flower, possessing remarkable qualities; flowers beautifully formed and of excellent type. A beautiful shade of mauve. \$1.00 each.

VARIEGATED LISZT-Dark oriental red, with yellow tips and markings. A superior rariety for decorations, especially whele a bronzy effect is wanted. 50 cents ench.

The entire Fift - $\mathrm{xix}$ distinet varieties of Dahlias as catilogued, costing, if ordered singly, $\$ 22.10$, sent for a renittance of $\$ 18.00$ net.

\section{BEAUTIUL HOUSE FERNS}

There are so plants grown that are more desirable for the honse than the following fine decorative Ferns. They are easily grown, free from insects and diseasc, and thive weil in the ordinary temperature of the living roon. See that the plants have pienty of drainage and are hept wel! watered; never let dry ont for any leighil of tinc. Fuergone of these Nephrolepis Ferns is entirely distinct in every way. That we are hesdinaters for Ferns is cvidencen by the choice assortment that we ofier. No other firm offers so $3 a n$ wistinct and choice yarieties. Try us for Ferns.

\section{The "Teds'y Junion Fern"}

Nephrolepis Tedd Junior

"Teddy Junior," the Fern for every household. This grand Fern was introduced recently by G. \& R. The fronds are broad and beautifully tapered from base to tip; they droop just enough to make a shapely, graceful plant, permitting it to finish with a fine full center and perfect symmetrical spread. The pinnae are distinctly undulated, giring the fronds an attractive wavy appearance, which adds materially to their charming decorative effect. "Teddy Junior" wili proauce about four times more fronds than any other Fern ever introduced, finishing with fifty to sixty fronds in a four-inch pot. Fine soung plants, 25 cents; strong plants, 75 cents.

\section{The "Roosevelt Fern"}

\section{Nephrolepis Roosevelt}

It is our good fortune and great pleasure to offer this wonderiul new Fern, having introduced it in 1910. In this short time it stands second in popularity of all the Ferns, and will soon be more populav than even the old favorite Boston Fern. In sencral characteristics it resembles the worldfamous Boston Ferm, but it will sweep that Fern from the boards for two reasons; it produces many more fronds than the Boston; thus making a bushier, handsomer plant; then the pinnae are bealififully undulated, giving the "Rooserelt" a jronounced wavy effect seen in no other. Fern; as charming and most notable variety. Fine young hlants, 2u cents each; strong plants, 65 cents.

\section{New Fern Liberty}

This is our own production. In the past we have sellt out Baby's Breath, Teddy Junior and Roosevelt, the three greatest Ferns today, acknowledged
so by all plantsmen and flower lovers, and now we add another one to the galaxy, "Liberty," no doubt the best of then. All the fronds have finely divided pinnae that give them a very beautirul appearance, while the whole plant is overlaid with a bluish cast that makes of it a very striking object. Wonderfully beautiful, difierent from all other Ferns. First time offeleds. Aine soung plants, 35 cents each: strong plants, \$1,00 each. Be sure and try this beautiful Fern.

\section{The "Newport Fern" Vephrolepis Scottì}

Of much dwarfer and bushier growth than the Boston Ferm. The fronds droop gracefully, and are not as long and heavy as the Boston. It is a rapid grower, and to see it in all stages of growth from a runner in the bench to a 14 -inch pot specimen will convince you that it will be in great demand as a house Fern. This has always been a favorite variety. Fine soung plants, 30e; strong plants, 75.

\section{The "Parlor Fern"}

Tephrolepis Whitmanii Compacta

This is a condensed form of the "Ostrich Plume" Fern, with valuable characteristics added which are not evident in the parent. the pinnae subdividing. making miniature fronds which are superimposed on the main fronds, looking as if two or more were condensed into one. Graceful beyond description Fine roung plants, 35 cents; strong plants, 75 cents.

\section{The "Philadelphia Lace Fern" \\ Nephrolepis Elegantissima}

The small size pinnae, or leaflets, are subdivided into perfect miniature fronds the side pinnae stand at right angles to the midrib of the fronds, on edse instead of flat, giving both sides of the main frond the same beautiful appearance. It is impossible to conceive of the beauty and grace of this wonderful Fern from the description. Fine young plants, $3:$ cents; strong plants, 75 cents.

\section{The "Big Four" Fern} Nephrolepis Splendida

This is the most wonderful Fern of them all; it originated with $G$. \& $R$., and is now offered for the first time. It combines the good qualities of the four most popular sorts. It has the grace of a "Boston," the wavy effect of a "Rooserelt," the fluffy effect of an "Ostrich Plume," and the uniqueness of a "Fish Tail." Some fronds will be straight "Boston," others will be true "Roosevelt," in others the ends of the pinnae will be the feathery "Ostrich Plume," while in others the ends of the pinnae will be the genuine "Fish Tail." Then again some fronds will have in a marked degree all of these desirable traits, forming a combination without parallel among Ferns. It well deserres the name of "Bis Four Fern." Everyone who sees it goes "daff about it This is without question the most splendid of all the Nephrolepis. Be sure and try it. Fine rouni plants, 25 cents each; strong plants, 75 ceuts 


\section{Beautiful House Ferns-Concluded}

The

\section{"Boston}

Bostonicnsis.

In the vicinity of

$\mathrm{B}$ os to n, no other plant is so extensively used as this graceful Nephrolepis, which differs from the ordinary sword Fern in having much longer fronds, which frequently attain a length of six feet. These areh and droop over very ra c e fully, on account of which it is frequently called the Fountain Fern.' This drooping hab it makes it an excellent plant to grow as a single specimen on a t a b l e or pedestal. This Fern should not be compared with the Ostrich Plume Fern, as they are of an enti le ly different growth. Fine young b 1 a $t s$, 25 cents: strong $p$ a $\mathrm{n}$ is,

\section{The "Wannamaker Fern"}

\section{Nephrolepis Joln Wannamaker}

A new Fern of wonderful beauty. Long, narrow, gracefully drooping fronds. It is not so compact as Scholzeli, and, therefore, is a very airy and graceful Fern, and very durable in the house. A rapid growel; quite distinct from other Ferns. Fine young plants, 30 cents; strong piants, 75 cents.

\section{The "Ostrich Plume Fern"}

\section{Nephrolepis Whitmanii}

A great Fern. In fact, it is a plant that appeals to everyone, and on that account will prove a much more valuable and profitable plant than other Ferns of this class. Everyone who has seen it is charmed with it. As someone has expressed it, "There is nothing like the Ostrich Plume Fern in cultivation. In decorative effect it so far outdistances the original variety that there is positively no comparison to be made. We consider it the nost valuable novelty that has heen introduces? in many, many rears." it has taken gold medals wherever shown. Fin sound plants, 3.5 cents: strong indants, s.5 cents.

\section{Fern Smithii}

A new type of the Ostrich Plume family. The frond is very compact and the pinnae are finely serrated, giving it the appearance of a strong feathery plume. Fine ronnz plants, sil cents each. No large size to offer.

\section{The "Old Original Sword Fern"}

\section{Nephrolepis Exaltata}

This is the "old original Sword Fern," the "daddy" of them all, the one plant from which all the vephrolepis we offer sprang. It is entirely different flom any of its progeny, having narrow fronds that are long and of very erect growth. For this reason it is more largely used as a centerpiece in vases SPECTAL OFFER-The Fifteen Beautiful Ferns as than are any of its descendants. Fine soung glants, 25 cents; stronus plants, 75 cents.

\section{The "Crested Fern"}

\section{Nerbrolepis Selnolzeli}

The fronds are crested and stand erect, with a graceful arch, forming a plant of ideal shape, and they never break down, giving the plant a ragged appearance, as is so often the case witl other plumed forms; furthermore, the loose, elegant arrangement of the fronds, allowing a free cilculation of air through the foliage, prevents the ccnter of even the largest specimen from becoming defective or yellow. Fine youms plants, 25 cents each; latede hants, 50 cents.

\section{The "Baby's Breath Ferr"}

\section{Nephrolepis Goodii}

This has the finest foliage of all the Ferns. It is so delicate that a lady on seeing it exclaimed, "Call it the Baby's Breath Fern, as it is so dainty in tex. ture that a baby's breath would set its fluffy ioliage in motion." The fronds are very fine and filmy, on which account it has been called by some the Lace Fern. It is an improved variety, and the best of it: type. Nothing is daintier or mole exquisite than well grown specimens in any size. Fine young plants, 50 cents; strong plants, s1.06.

\section{The "Fluffy Rufles Fern"}

\section{Nenhrolepis Superbissina}

This new Fern is quite different from all othe Ferns. Its distinguishing eharacteristics are it dark green foliage, darkel than any other Fern, its dense growth, much more compact, and its irreguial shaped fronds, which give it the name of "Flutf. Ruffles Fern." The fronds are very heavily imbricated, the pinnae overlapping, and so formed as to resemble miniature Ferns, giving it the appearance of a Fern within. a Fern. The plant is very sturdy size to ofler.

named. costing \$5.25, for only \$4.25. The Therteen Ferns in strong plants, costing $\$ 10.10$, for only $\$ 9.50$. 


\section{Dwarf Ferns for Fern Dishes}

We have selected a few of the hardiest and most satisiactory varieties for filling Fern dishes, than which there is no prettier table decoration for winter. Price, 10 cents each, or we will send five distinct Dwarf Ferns for 45 cents. We have six other distinct Dwarf Ferns.

ASPIDIUY TSUSSIMENSE-The most valuable for Fern dishes; of strong, but dwarf and graceful habit, of good color and of the best keeping qualities. A clean, good grower and very ornamental.

CYRTOMUM FALCATUI, or HOLLY FERY - A beautiful and rapidy growing Fern that succeeds exceedingly well, small plants making fine spe- cimens in a short time. Fronds resemble branches of holly, from which it takes its name.

PTERIS MAYI-A rariegated variety. Low-growing and suitable for edging Fern pans or dishes.

PTERIS WIMSETTI-A beautiful low-growing Fern, suitable for table dishes.

PTEHis WILSONII-The most beautiful and usefuI of all the crested sorts for pans or dishes.

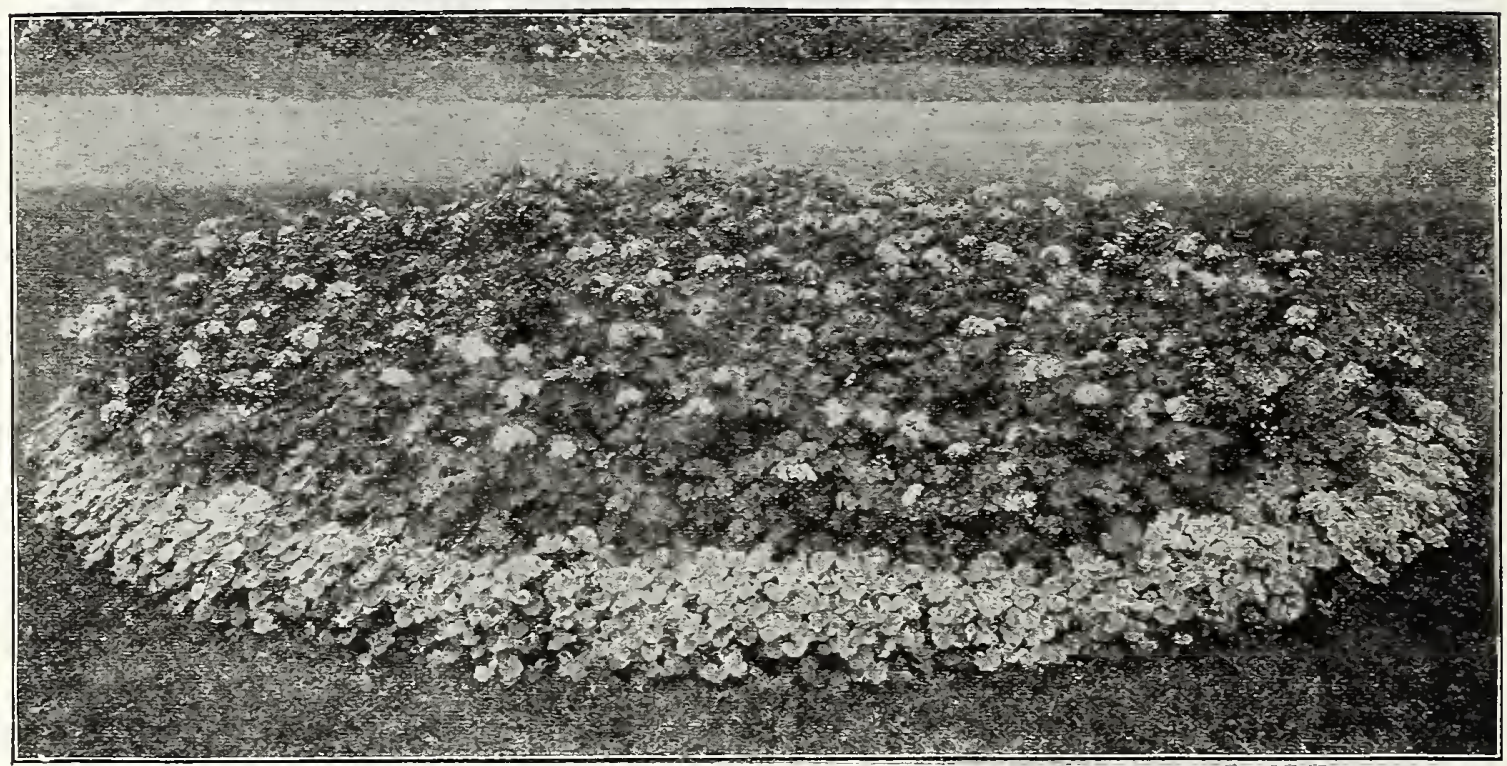

\section{DOUBLE GERANIUMS The Best There Are}

\section{PRICE, 20 CENTS EACH; ANY THREE FOR 50 CENTS}

ALPHONSE RICARD-A most beautiful shade of bright vermilion; large flowers and enormous trusses; a grand variety.

AiERICAY REAUTY-(New.) Same color as the famous American Beauty Rose. A very free bloomer.

BEAUTE POITEVINE-Beautiful shade of shrimppink, gradually shading to white; a universal favorite.

CONTESSE DE HARCOURT-Beautiful florets and enormous trusses of pure white. Stands the sun well.

E. II. TREGO-A beautiful shade of dazzling scarlet with a pleasing soft, velvety finish on a saffron ground. Excellent. The trusses are so freely produced as to nearly conceal the foliage.

HELEN MCHELL-(New.) The clearest possible shade of scarlet, borne on gigantic trusses.

HETERANTHE, or Double General Grant-Color of the flowers is a light vermilion-red of a most pleasing shade. The flowers are absolutely perfect in shape, contour and make-up, trusses exceptionally large and borne in immense spherical balls, often measuring eight inches in diameter. Is perfectly reliable as a bedding Geranium of the highest merit.
JEAN OBERLE-A most beautiful peach-plnk color shading to hydrangea-plnk. Superb.

JEAN TIADD - This is the best large-flowering double pink Geranium in cultivation. The color is the richest deep pink, shading near the base of the petals to light pink, the base of the upper petals creamy-white.

JOHX DOYLE - Rich deep scarlet, exceptionally bright and effective.

LA FAVORITE-In this Geranium we believe we have the finest double white Geranium in cultivation. The flowers are borne in large trusses of the purest snow-white, retaining this pure whiteness even in the height of summer, and for winter blooming they are all that can be desired. Do not fail to add this charming variety to your collection.

MADAME BARNEY - A profuse bloomer; florets enormous; color a deep, pure pink. A perfect bedder.

MADAME JAULIX-A continual bloomer; color daybreak pink, shading to a delicate peach-pink; enormous trusses.

MADAME LANDRY-A distinct salmon-pink with a slight scarlet shading. Enormous trusses and florets borne on long stems. 


\title{
Double Geraniums-Concluded
}

MARQUIS DE CASTELLANE-This is a deep solferino in color; has a splendid habit, and the color is decidedly unique and bright for a Geranium. An exceptionally striking variety.

MISS FRANCES PERKINS-A constant bloomer of a charming deep rose-pink color, with a distinct white throat; stands the climate well.

MRS. LAWRENCE-This is one of the finest Geraniums. The color is an artistic shade of bright satiny salmon-pink, slightly tinged white.

RED WING-Deep cardinal-red with a soft velvety sheen, unusually attractive.

S. A. NUTT-This is the darkest and richest Geranium known. It is very bright, dark, deep, rich, velvety maroon: an excellent bedder and a perfect pot plant. One that must find its way into every collection.

\section{SINGLE GERANIUMS None Better Than These Varieties}

20 Cents Each. Will Send Three Single Geraniums, Our Selection of Varieties, for 50 Cents.

ALICE LEMON-Very light pink with a dark pink eye.

ALBION-One of the finest single whites. Pure in color; immense in size; circular form.

JACQUERIE-A most beautiful shade of deep carminered; immense trusses; fine bedder.

L'AUBE-Enormous trusses, large, round florets, pure snow-white, retaining its pureness the entire season.

MADAME MOSNAY-A magnificent shade of red. Upper petals shaded violet to white center; unsurpassed.

MADEM OISELLE ANASTASIE LECARDE-Rich crimson carmine-lake, shading through a maculated effect to a pure white center. Extra fine.

IRS, E. G. HILL-Profuse bloomer, soft light salmon. Each petal bordered with rose-salmon. Exquisite.

TIFFIN-Very effective shade of rich glowing scarlet.

\section{Sweet-Scented Geraniums}

20 cents each; three for 50 cents.

LEMON-The foliage is pronouncedly lemon-scented. NUTMEG-Foliage has true nutmeg fragrance.

ROSE - The famous sweet Rose-scented Geranium; very fragrant.

\section{Pansy Geranium, Mrs. LAYA L}

\section{A Wonderful Plant.}

This new and wonderful Pansy Geranium is of the easiest growth, dwarf in habit, and literally covered with flowers all the time; and as it requires little or no attention, it is invaluable as a window plant. The coloring and markings of the flowers are most extraordinary-light pink, white, dark purple, black, etc., almost rivaling the Pansy in uniqueness of flower. It is this combination of coloring which obtained for it the popular name of Pansy Geranium. Strong plants, ready to bloom, 30 cents each, two for 50 cents.

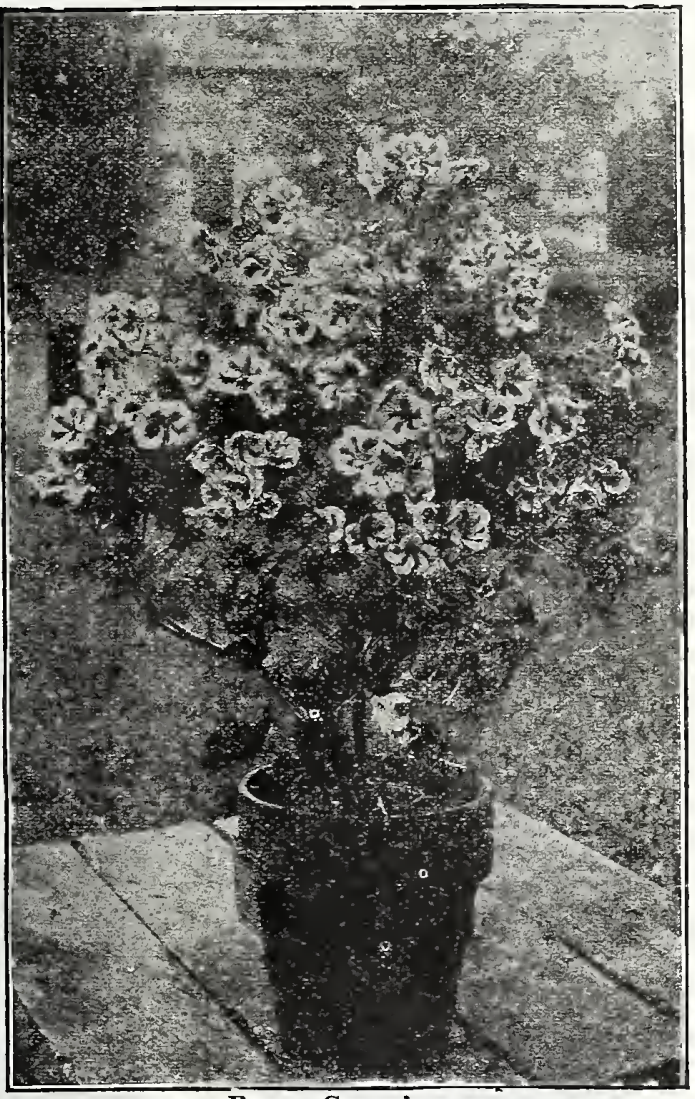

Pansy Geranium.

\section{Pelargonium, or Lady Washington Geraniums}

The grandest of all flowering plants; do not resemble the common Geraniums in any particular, neither in foliage nor flower; more beautiful in every way. We here offer six distinct sorts, every one entirely different in color and every one a beauty. The Lady Washington Geraniums are the handsomest of all flowers-once seen, never forgotten.

\section{The Easter Greeting, or Ever-Blooming Set}

\author{
PRICE, 40 CENTS EACH
}

EASTER GREETING - Planted out as a bedding plant it will bloom continually until late in the fall. It will prove the forerunner of a new race of ever-blooming kinds, as it rivals the Orchids in beauty. This new species is the earliest of all Pelargoniums, with enormous florets and clusters, having light green foliage and of dwarf, robust growth. It blooms from March until fall. Florets fiery amaranth-red, with five large, regular shaped spots. The first and only kind to bloom as well bedded out as in pots, and to do so all summer.
GARDENER'S JOY-The ground color is apple-blossom pink, the two upper petals have blotches of carbon-brown, the florets are three and one-half inches in dianteter and are joined to enormous clusters which rise above the beautiful foliage and remind one of a Rhododendron cluster. It is of a half dwarf nature and very sturdy. On account of its rapid, Iuxuriant growth it is a very profitable market variety. 


\section{Pelargonium, or Lady Washington Geraniums-Concluded}

GLORY-This splendid novelty is quite remontant fiorets and cluster very large; ground color, Cattleya-blue, very much like the Cattleya Orchid. The upper petals contain two large purple magenta-red spots, distinctly veined. ingly beautiful and entirely new color in Pelargoniums. This kind has a very robust growth.

LIBERTY - A glorious flower of salmon-red, with large velvety, sharply defined blotches bordered with scarlet. Has all the good qualities of Easter Greeting, its parent, having gigantic trusses. Equally valuable as a pot plant or for bedding
LUCY BECIKER-This grand novelty is a sport of Easter Greeting, and is like it in everything but color which is a rosy-pink. It is if anything even more free in bloom.

PRINCE-Immensely large flowers, strongly crimped of fine shade, with from six to ten petals; color rich purple with velvety black blotches. Pemarkably robust habit. The large clusters rise gracefully above the beautiful foliage. The blooming plant with its enormous flowers makes a striking plant with

\section{THE NEWEST FRENCH HYDRANGEAS}

These are very fine and claimed to be an improvement over the older sorts.

All the following Hydrangeas, young piants, 75 e each.

BABY BHBINET-Very dwarf, free and early; large, compact trusses of silver-rose flowers very attractive

FTINCETANT-A clear carmine. A clean, vigorous grower of unusual merit.

SATINET-This variety is so radiant that it resembles a dainty piece of stain, probably the best of all the French Hydrangeas. Color a beautiful rose.

mopHeE-The reddest red A vigorous grower free bloomer, of a deeper shade than Lilie MIouillere. Has been accorded the most unreserved praise of any variety grown by us. A real red and an excellent actor.

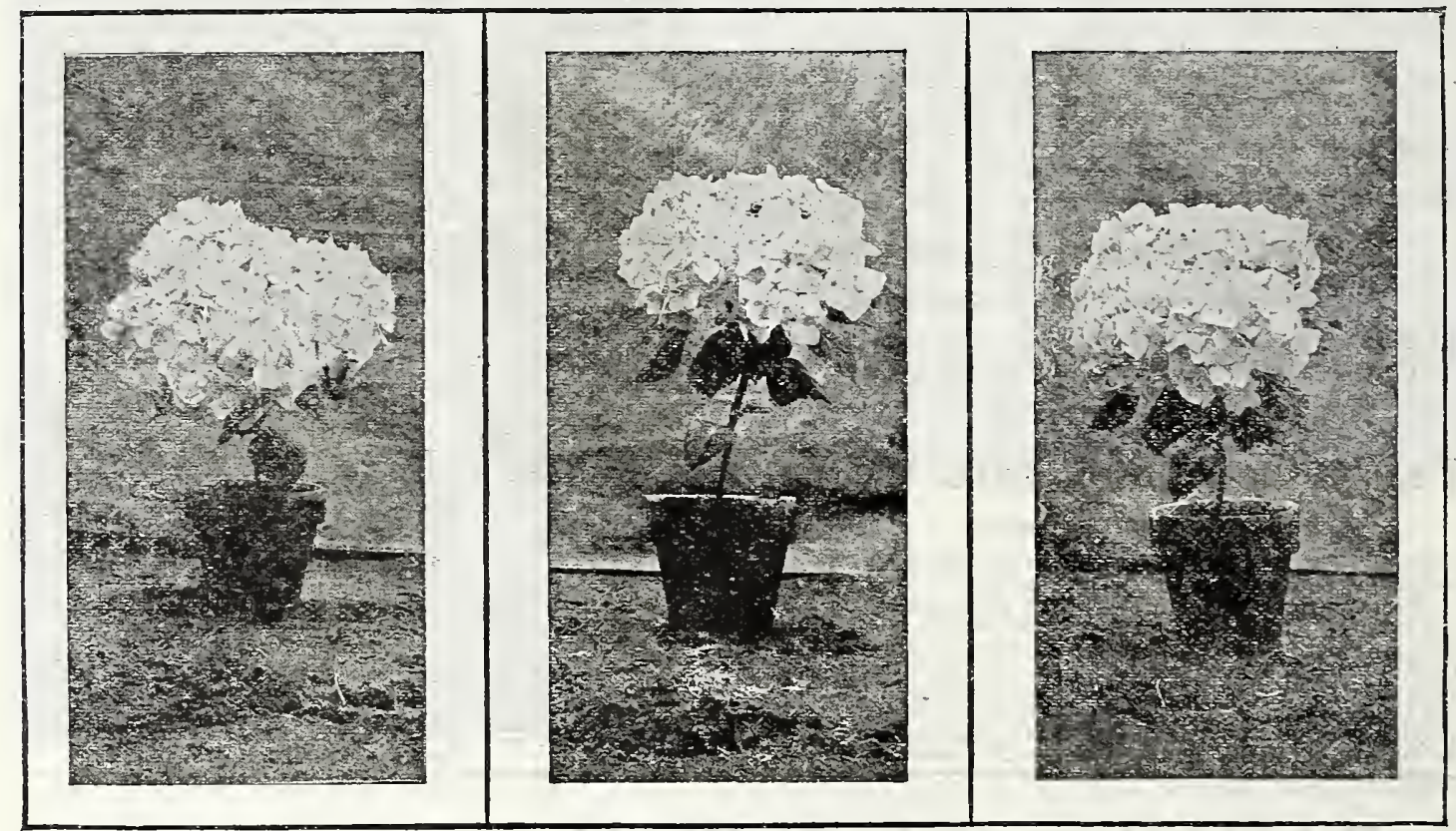

Hydrangeas.

\section{NEW FRENCH HYDRANGEAS}

Let us tell our friends that these new French Hydrangeas are the most meritorious plants brought out in years. They have enormous trusses of bloom that completely hide the plant. They are half liardy and may be planted in the latitude of Philadelphia and in the Gulf and Pacific states. They are also fine as house plants, blooming in the spring time about Easter. When kept at a temperature of 70 degrees out of doors they bloom about June. Ail the following New Hydrangeas, young plants, 30e; strong Ilants, 50\%.

AVALNCHE-A splendid large white, which has made a reputation for itself during the past two seasons. An easy variety. to force.

BOUaCET ROSE-Large trusses of well-formed fowers, rosy-amber turning to bright pink; has proven a special favorite in the New York market this season.

E. G. HILL-This is the newest one and the very best, and is by far the best pink that we have yet tried; trusses of immense size. Color a most pleasing shade of baby pink that does not fade. Growth vigorous, foliage large and attractive. It is one of the easiest to force into bloom during the spring, coming into flower early.

GENERAL DE VIBRAX - A favorite wherever seen. Very large heads of bright rose-colored fiowers. A splendid early forclng variety.

I.A LORIAINE-Large flowers; pale rose, turning to bright pink; has become a general farorite during the past two years. 


\section{New French Hydrangeas-Concluded}

LA FIRANCE-Very strong grower, with immense trusses of deeply fringed flowers of a delicate shade of rose.

LA PWRLE-The grandest, largest and most refined white we have yet seen; flowers deeply fringed.

LIIIE HOULLERE-Similar to, but distinct from Eclaireur; a bright carmine-rose.

MME. AUGUSTE Noviv-An unusually attractive pretty pale pink in heads of large size.

MME. D. MOULLERE-The favorite white variety in the New Yolk market this year; very free flowering, of good size medal at the National Flower Show at Boston last year. A great favorite with English growers, one London grower known to us handling over 30,000 of this variety alone.

MoUSSELINE (The Famons Bhe Hydrangea)With us a beautiful plumbago-blue. The introducer describes it as a beautiful mauve-rose with cream-colored center; flower heads are large and held erect; a decided acquisition. If you desire a beautiful deep Hydrangea flower get this one.

PRES. FALLIERES-Very delicate rose.

RADIANT-Very deep carmine, Extra fine.

SOUVENIR DE MADAME CHAUTARD-One of the best, of splendid erect habit; very robust. Fine sized heads of bright rose-colored flowers. One of the best of the bouquet type.

SEFCIAL, OFFER-The Fourteen Varictics costing $\$ 4.20$, sent for $\$ 3.50$ net.

\section{LIBERTY IRIS The "Fleur De Lis" of France}

No other flower has so many combinations of color, especially of the delicate and unusual shades, and the name Rainbow Flower is most fitting. They are absolutely hardy, as beautiful in form, texture and coloring as any Orchid, and many are delightfully fragrant. They are not particular as to soil; will -grow where anything will, but do better in well-drained locations. There is nothing prettier than this Liberty Iris, blooming from May 10 th to June 10 th. The colors are gorgeous and they completely hide the plant. Be sure and plant some Liberty Iris.

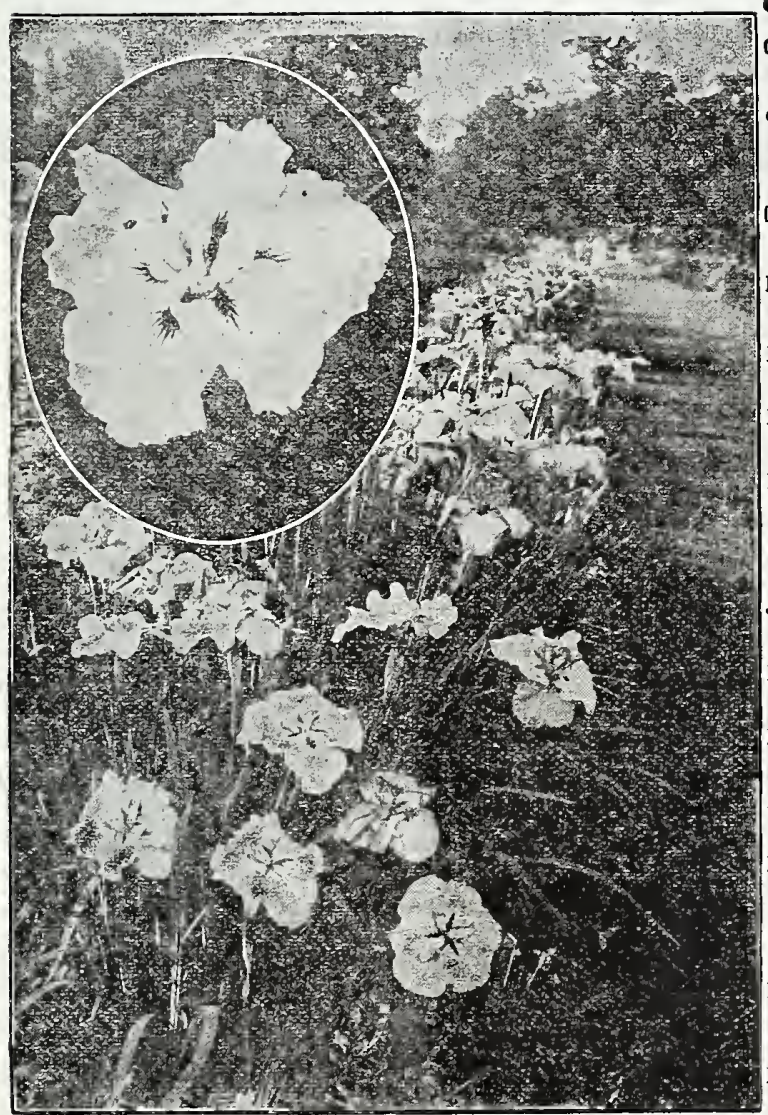

AMAS-S. rich blue; F. violet. 35 cents each.

ALBERT VTCTOR-S. soft blue; F. beautiful lavender; large and fine. 20 cents each.

AURFA-S. and F. rich chrome-yellow. Large flowers of perfect form. The finest pure yellow. 35 cents.

AUSTRALIS-S, deep lavender; F. soft blue. Very tall grower. 35 cents each.
CELESTE-Pale azure-blue. 35 cents cach.

GRACCHUS- $\mathbf{F}$, crimson, reticulated white; extra fine; early. 20 ceuts each.

GAGUS-S. light clear yellow; F. crimson, reticulated white and yellow, with a clear yellow picotee edge. 35 cents cach.

DARIUS-S. rich canary-yellow; F. lilac, margined white, rich orange beard. 25 cents each.

FLavescens - A delicate shade of soft yellow; large. 20 cents each.

HER MAJESTY-S. a lovely rose-pink; F. bright crimson, tinged a darlier shade. 35 cents each.

HoNORA BIl.IS - S. golden; F. rich mahoganybrown. 20 cents each.

INNOCENZA - S. and F. ivory-white, erest rich golden; very delicate and beautiful. 35i each.

IRIS KING-S. clear lemon-yellow; $\mathbf{F}$, rich maroon, bordered yellow, 50 cents each.

JUANITA-S. and F. clear blue, deeper than Dal matica; large, fragrant flowers. 50 cents ench.

LOHENGRIN-S. and $F$. uniform soft shade of cat tleya-rose; very large. 50 cents each.

LORELY-S. light yellow; F. ultramarine-blue, bordered cream. 35 cents each.

MAORI KING-S. rich golden-yellow; F. velvety crimson, margined gold. 35 cents eacl.

MADA IE CHEREAU-White, elegantly frilled with a wide border of clear blue. 25 ceuts each.

MIRS. H. DARWIN-Pure white, falls slightly reticulated at the base. 20 cents cach.

PALLIDA DALMA'TICA-S. fine lavender; F. clear deep lavender; flowers very large; extra fine. cents each.

PURPLE PHINCE-S. intense deep violet-blue; F velvety dark purple. 20 cents each.

QUEEN OF MAY-A lovely soft rose-lilac, almost pink, beautiful. 20 cents eacli.

RIER NIXE-S. pure white; $F$. deep violet-blue, with a white edge. 75 ecnts each.

SAMBUCINA-S. coppery-rose; F. rosy-purple, with an orange crest; very showy. 20 cents each.

SPEPIA OFFER The entire collection of 21 Iris, costiug \$7.55; sent for \$6.85. 


\section{SPLENDID Hardy Everywhere PEONIES}

\section{"ARISTOCRAT OF FLOWERS"}

7 HE wonderful improvements made during recent years in these old-fashioned hardy plants has brought them into renewed popularity. The gorgeous flowers, which rival the finest Roses in size, form and color, are produced in great abundance. After once being planted they require little care and attention, thrive anywhere, and are absolutely hardy even in the coldest climates; each year after planting they grow into greater value, producing more and more flowers. They are not troubled with insect pests. Try some of our fine Peonies, and see what grand flowers they are. Get it out of your head that there are only Red, White and Pink Peonies to illustrate at flowering time. People who visit our field will say, "I have Pink and White Peonies. I desire only Red ones," but when they are shown the Pink and White, they invariably exclaim, "How grand! I have none like them." There is as much difference in Peonies as there is in Roses.

\section{SPECIAL COLLECTION OF PEONIES}

To those who do not care for the nomenclature of the Peony, we have made up aereraI collections, and here offer them as an aid to making selections. Patrons will find these varieties embrace a wide range of color and form, and are exceptionally meritorious.

\section{COLLECTION A}

This collection embraces the Peonies of merit that are a great bargain at the prices here quoted.

33-AUGUSTE LEMONIER

Each

34-CHARLEJI GNE
349-COUTE DE NA TTEUIL

349-COJTE DE NANTEUIL.

35-FRAGRAN

3-HU IIFI

PENSABLE

$35-L I N N E$

66-MADEMOISELLE DESBUISSONS

61-NE PLUS ULTRA.

The 10 Peonies from Collection A for....... \$\$\$.00 COLLECTION B

Thls collection includes a list of choice varieties at popular prices. Much lower in cost than you can buy elsewhere.

11S_BOTEE DE NEIGE, or BALL OF SNOW.. Sach 11-DUCHESS DE NEMOURS.

46-JEN N L LND

2-LOUIS VAN HOUTTE.

106-IIDAJIE BOLLET.

19-IIADAME CALOT.

16-MADAME DE VERNEVILLE

25 II D IE LEBON

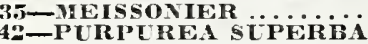

.60

.60

60

.60

.60

.60

.60

.60

$\$ 6.00$

The 10 Peonies from Collection $B$ for........\$5.00

\section{COLIECTION C}

This collection includes some of the wonderful reations of recent introduction. Should sou not care for all, at least try some of them, and you will thank us for our recommendation.

15-MADFMOISFLLE LEONIF CALOT. . . . \$ \$ \$1.00 130-YIARE JACQUTY L.... 246-IIA TERPIECE

152-MIODELE DE PER FECTION

48-VONSIEUR JULLS ELIE.

169-PHILOMEL.

50-PRINCESS BEATRICE:

49-RACIIEL (Terry).

7S-RUBRA SUPETBA

.

The 10 Peonies from Collection $C$ for $\ldots$

\section{COLLECTION D}

Try this Collecticn if you are a lorez of finc Peonies.

111-ALEATRE

Each

$\$ 127$

12 -ALIFR' CROUSSE.

1.25

ä-RILIX CROLSSF

110-GLOIRE DE CHARLES GO IIBALT.

SO-GPANDIFLORA

149-L TOSIERE.

1.1-MATHILDE DE ROSENECK

15S-MIODESTE GUERIN

153-UONSIFUR DEPOAT

The 10 Peonies from Collcction $\mathrm{D}$ for.......\$11.50

\section{COLLECTION E}

This collection covers the entire range of form and color in the Peony. We challenge comparison as to their great beauty amd to the very loiv prices we offer them. Not a single Peony here will disappoint sou.

98-ANDRE LACRIES . . . . . . . . . . \$0.75

Each

242_BELLE CHA TELAINE. . . . . . . . . . . . .

230 -BELLE DOUAISIEN NE. . . . . . . . .

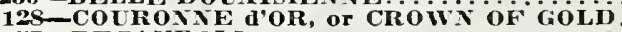

$157-D E C A N D O L L F$

53-DELACHEI

22-DLC DE VEL

22 .

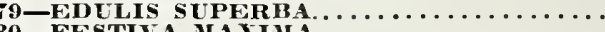

4-FLORAL TREASURE. $\ldots \ldots \ldots \ldots \ldots \ldots \ldots \ldots \ldots .75$

$\$ 7.50$

The 10 Peonies from Collection $\mathbf{E}$ for.........\$\$ \$.50

\section{COLLECTION F}

These Peonies are one and all a marked triumph of the hrbridizer's skill and patience. All will be sure to please sou.

dיARC . . . . . . . . . .

28_LA DY LEO NORA BRA MUELL . . . . . . . . .

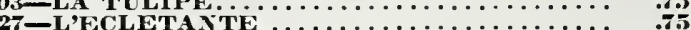

197-MADA ME DE VATRY

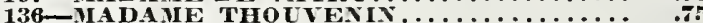

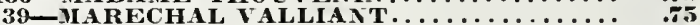

10-MIARIE STUART ...................

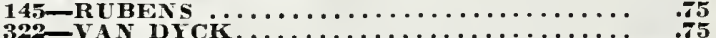

10 P.50

The 10 Peonies from Collection $\mathbf{F}$ for.......\$6.50 COLLECTION G

In this collection will be found the finest of all Peonies. Every one a masterpiece. None better.

Each

102 - ASA GRAY . . . . . . . . . . . . . . $\$ 1.00$

228 A UGUSTIN d'HOUR . . . . . . . . . . . . 1.00

97-DORCHESTER .................

67_GOLDEN HARVEST..............

$175-J U L E S$ CALOT. . . . . . . . . . . . . . 1.00

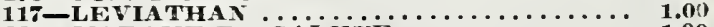

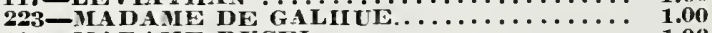

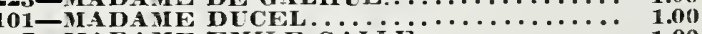

7-MADA ME EMILE GALED............

32-DIADADE FOREL..............

$\$ 10.00$

The 10 Peonies from Collection $G$ for . . . . . . . .\$\$ \$0.00

COLLECTION H

A splendid collection of wonaerful Peonies. Racl

170 -AUGUSTE VILLA TIE. . . . . . . . . . \$1.50

81-ADOLPHE ROESSEAL ..............

79-B EA UTE DE VILLECA

168 LIVINGSTONE $\ldots \ldots \ldots \ldots \ldots \ldots \ldots \ldots \ldots$

51-PRESIDENT ROOSEI ELT.......... 1.5.

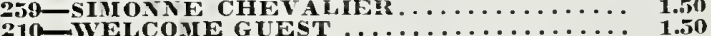

$\$ 10.50$

The 7 Peonies from Collection 11 for........ $\$ \$ .50$

\section{COLLECTION K}

Plant this collcetion if you care for something special.

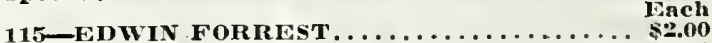

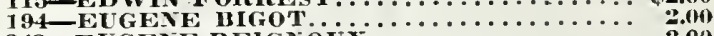

243-EUGENE REIGNOUX..............

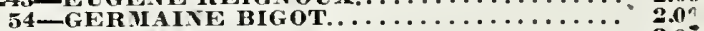

9-GIGANTEA ...................

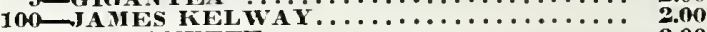

190 LA FAYETTE. . . . . . . . . . . . . . . .

The 7 Peonies from Collection $K$ for........\$I3.00 


\section{THE CREAM of the PEONIES}

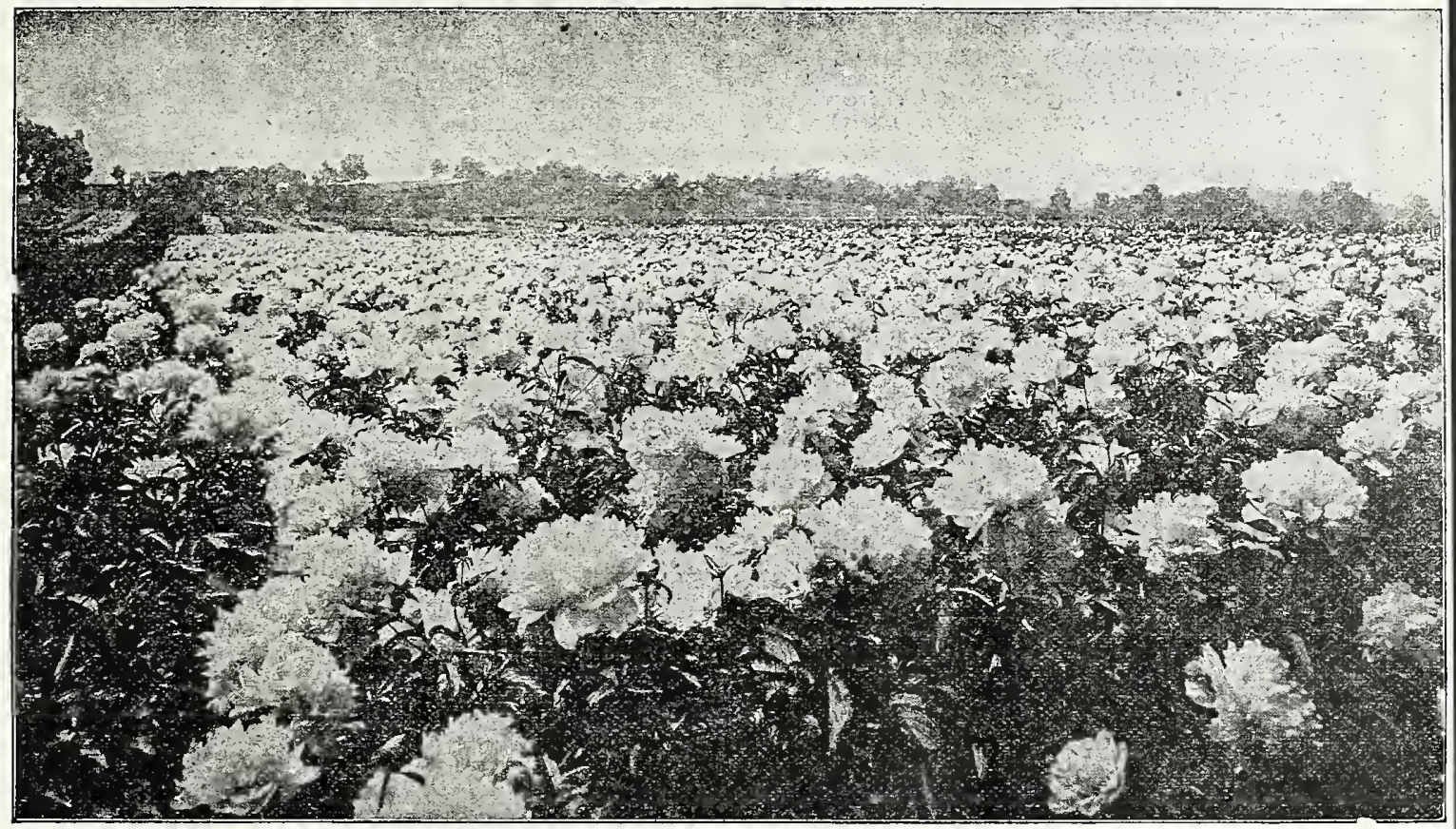

You may order by the number preceding the varieties or by name, or better still, in oriering use both number and name. For full and complete description of these Peonies send for our booklet, "Peonies for Pleasure", It is mafled free. It also describes and prices over a hundred other choiee kinds, both new and old, that are not named in this catalogue. Send for it today. All Peony roots here offered are known as Divisions. If you want larger roots send to us asking for our prices on one, two and three-year roots.

81-ADOLPHE ROUSSEAU (Dessert and Mechin 1890)-Large, dark, velvety crimson with garnet hues. \$1.50.

141-ALBA TRE (Crousse, 1885)-Rose type, midseason; one of the finest of all white Peonies. \$1.25.

12-ALBERT CROUSSE (Crousse, 1893)-The color is an even, delicate sea-shell pink; nothing finer. by many considered the best of all Peonies. \$1.25. 35-AMERICAN BEAUTY-A glowing red bomb type. Midseason. Known in the cut flower market as the "American Beauty Peony"; superb. $\$ 1.00$.

98-A N.DRE LAURIES (Crousse, 1881)-Very dense compact globular bloom of the largest size; color dark Tyrian-rose or solferino-red shading deeper in the center. 75 cents.

T05-ARSENE MURET (Verdier, 1854)-Semi-rose type. Midseason. Large globular flowers clear violet-rose tipped silver. \$1.00.

102-ASA GRAY (Crousse, 1886)-Large, full, imbricated rose-formed bloom, guards salmon-flesh. center of flower flesh-pink, dotted carmine. \$1.00.

23-AUGUSTE LEMONIER (Calot, 1865)-Superb brilliant red with velvety finish; fragrant. A very popular variety. 50 cents.

170-AUGUSTE VILLAUME (Crousse, 1895)-Enormous full round bloom. Color a uniform rich violet-rose. Took prizes at Cleveland show. \$1.50. 228-AUGUSTIN d'HOUR (Calot, 1867)-An extremely large and showy flower. Color very deep rich brilliant solferino-red. Indispensable \$1.00. 132-AVALANCE (Crousse, 1886)-Color pure snowwhite with a few delicate pencilings of carmine on edge of central petals. \$1.25.

279-BARONESS SCHROEDER (Kelway, 1889)-Immense size, forming a huge pyramid of baby pink, changing to pure white; extra fine. \$2.50.

179-BEAUTE DE VILLECANTE (Gombault, 1856) -Guards and crown violet-rose. Collar lilacwhite; free bloomer; fragrant. \$1.50.
242-BEILE CEATELAINE (Guerin 1861)-Medium sized flower. Color mauve-rose with amber-white collar and center, fragrant. 75 cents.

230-BELLE DOUAISIENNE (Calot, 1861)-Large globular flower, color hydrangea-pink; center prominently flecked crlmson; very fragrant. $75 c$.

118-BOULE DE NEIGE, or BALL OF SNOW (Calot 1862) - Large cup-shaped bloom. Color milkwhite, sulphur center, prominently flecked crimson. 60 cents.

187-CARNEA ELGGaNs (Calot, 1860) - Perfect shaped flowers with broad petals; clear flesh color with glossy reflex mixed with small yellow petals. This is as pretty a flower as any Peony we grow. $\$ 1.25$.

34-Charlemagne (Crousse, 1880)-A Peony that has many admirers; blooms late. Color a delicate tint of lilac or heliotrope. Grand. Jor

127-CLAIRE DUBOIS (Crousse, 1886)-Very large rich, clear satiny-pink with glossy reflex. \$2.50. 89-CLEMENTINE GILIOT (Crousse, 1885)-Very large double flower of great beauty. Color a uniform shade of light clear rose, at once attractive and beautiful. \$1.25.

349-COMTE DE NANTEUIL (Calot, 1858)-Guards violet-rose, center clear salmon-pink, fragrant very free bloomer. 50 cents.

128-COURONNE d'OR, or CROWN OF GOLD (Calot 1873)-Very full, imbricated, ball-shaped bloom; color snow-white, with golden-yellow stamens showing through the sides of the petals. A wonderful Peony. 75 cents.

157-DECANDOLLE (Crousse, 1880)-A novel and attractive color, blooming in clusters; currantred, shaded with vivid amaranth. This will please you. 75 cents.

53-DELACHEI (Delache, 1853)-Rose type. Late midseason. Simply grand. A dazzling red. $75 \mathrm{c}$ 


\section{THE CREAM OF THE PEONIES-Continued}

97-DORCHESTER (Richardson, 1870)-An upright grower; color a delicate hydrangea-pink $\$ 1.00$.

22-DUC DE WELLINGTON (Calot, 1859)-Flowers of enormous size, really gigantic, pyramidal in shape with high built center. Snow-white guards. Center sulphur-white changing to snow-white. 75 cents.

41-DUCHESSE DE NHMOURS (Calot, 1856)Superb cup-shaped; sulphur-white flowers, fading to pure white. In all Peonies there is nothing so exquisitely chaste and beautiful as this variety in the half open bud state; excels as a cut flower. Don't omit it. eo cents.

9-EDULIS SUPERBA (Lemon, 1824)-This inight be called the Decoration Day Peony, as it with us is always in bloom for Decoration Day. Our field of thirty thousand plants in full bloom on that day is a sight never forgotten. Bright clear pink of the purest tone. 75 cents.

115-EDWIN FORREST (Hollis, 1906)-Large convex-shaped flower, very full and double; color bright red with silvery reflex. \$2.00.

94-ELIE CHEVALIER (Dessert, 1908)-Opens a large globular bomb, finishing a high built crown. Color a uniform Tyrian-rose, center elegantly flecked with crimson; fragrant. \$3.oo.

194-EUGENE BIGOT (Dessert, 1894)-Large imbricated flowers of perfect shape, bright brilliant velvety red with garnet hues. Extra. \$2.00.

243-EUGWXE IREGNOTX (Dessert, 1905)-Large globular loose flowers; color carmine-pink shaded purple; an attractive color. \$2.00.

93-EUGENIE VERDIER-The flowers are large. Color a delicate hydrangea-pink, with primary petals lighter, center flushed crimson. \$1.00.

202-FAUST (Miellez. 1855) - Guard petals and crown hydrangea-pink, changing to li lac-white collar of narrow sulphur-yellow petals. 50 cents. 25-FELIX CROUSSE (Crousse, 1881) - A rich, even, brilliant ruby-red. A grand red Peony. \$1.25.

30-FESTHA MAXIMA (Miellez, 1851)-This is not only the finest white in existence, but in most quarters it is regarded as the queen of all the Peonies. 5 cents.

4-FLORAL TREASURE (Rosenfield, 1900)-Very large, full flowers of clear even pink, shading lighter at the center; a very delicate color and a most beautiful Peony. 75 cents.

3S-FRAGRANs (Sir Joseph Banks, 1805) - Soft delicate pink, interspersed with salmon; an exceeding grood, perfect bloom and a pretty flower highly fragrant. 50 cents.

51-GERMAINE BIGOT (Dessert, 1902) - Crown type; inidseason. Form of bloom flat, very large and compact: color pale lilac-rose; guards precoloring. collar same color as ouards: flee lloomer borne in clusters; strong, elect grower. We do not think there is a prettier Peony grown than this one. \$2.00.

9-GIGANTEA (Lamartine Calot, 1860)-Flowers of enormous size of a clear bright pink color. Nothing finer. A wonder. \$2.00.

110-GLOIRE DE CHARLES GOMBALLT (Gombault, 1866)- We have no hesitancy in saying that this is the best of all the tricolor varieties. The colors are as well defined and clear cut as a cameo, beautiful. Rose and creamy-white with shades of salmon-yellow. \$1.25.

67-fiOLDEN HARVEST (Rosenfield, 1900)-Very striking variety. Tlis Peony combines cream, total color effect of the flower creamy-pink strong, delicate fragrance; a splendid bloomer extra fine. \$1.00.

SO-GRANDIFLORA (Richardson, 1883)-Its immense double flowers are borne in greatest pro-
fusion. Color bright sea-shell pink overlaid with delicate lilac and salmon-pink. So fairy like it reminds one for all the world of huge butterflies hovering over the plants. It is a wonder. \$1.25.
3-HUMEI (Anderson, 1810)-Very large, compact, pink flower with delicious cinnamon fragrance. 50 cents.

100-JAMES KELWAY (Kelway, 1900)-Very double and full, borne in immense clusters. Color pure white overlaid with a flush of delicate bridesmaid-pink, tinged yellow at the base of the petals. Extra fine. \$2.06.

122-JEANNE d'ARC-An early fine variety; creamgold and salmon-pink. 75 cents.

46-JENNY LIND (Burr)-Large bloom on long stems, free bloomer, color deep pink with silvery reflex. A most striking variety. 00 cents.

175-JULES CAIOT (Calot, 1861)-Large, rather flat flower, dark carmine-pink with a pronounced silvery reflex, free bloomer. \$1.00.

2S-LADY LEOXORA BRAMWELL (Verdier, 1854) -This is a charming large, full and exceedingly fragrant flower of perfect symmetrical form The color is a delicate silvery-rose with lively pink center. 75 cents.

190-LA FAYETTE (Dessert, 1904)-The flowers are of great size the color is a lovely shade of salmon-pink with touches of heliotiope and a delicate tinting of cerise in the reflex. A five-year plant of this variety in bloom is a sight never to be forgotten. \$2.60.

149-LA Rosiere (Crousse, 1858)-One of the most charming of all Peonies. Every woman that sees it wants it. Opens in huge clusiers of purest white and gold. Exceedingly beautiful. \$1.2.

103-LA TULIPE (Calot, 1872)-Enormous flowers, delicate blush-white, with pronounced stripes of carmine both on the face of the flower and on the bud before opening. Considered by all as a very choice variety; remains in bloom full two weeks. 75 cents.

27-L'ECLETANTE (Calot, 1860)-Flowers double and full. Color deep brilliant velvety red; superb. 75 cents.

117-LEVTAHAN (Kelway, 1899)-As its name would indicate, this is a leviathan as to size. Has large petals, color deep bright rose, a color that is rather scarce in Peonies. Extra. \$1.00.

27-LINDISPENSABLE (Origin unknown) - A huge ball of delicate baby pink, vers double and bloom very late. This is often sold by some socalled Peony experts for Eugene Verdier. 50c.

135-LINNE (Verdier, 1860)-Large globular compact bloom; color bright pink; a much sought after variety. 50 cents.

16S-LIVINGSTONE (Crousse, 1879) - Rose type: late. Very full imbricated bloom; both buds and flowers are large and beautiful. Color pale lilacrose with sheen of silver. very free sure bloomer in clusters; upright, erect grower; fine cut flower variety. One of the prize winners. \$1.50.

S2-LOUIS VAN HOLTTE (Calot, 1S6 7 ) - Fine shapely bloom of dazzling red, an old favorite. 60 cents.

1S5-MADAME BARILLET DESCAMPS (Calot, 1868)-Color clear violet-rose changing to a delicate silvery-rose; fragrant. 75 cents.

106-1IADAIE BOLLET (Calot, 1867)-Very compact olobular double bloom; color clear rose with silvery-white reflex; fragrant, free and fine. 60e.

10-UADAME CALOT (Miellez, 1S56)-This is the freest flowering of all Peonies. It is known in Holland as the Glory of Boskoop. Flesh white, shaded salmon; large convex flower, fine buds; extra for cut flowers. co cents.

223-MADAME DE GALHUE (Crousse. 1S\$3) Gualds rose-white center pale lilac-rose, free bloomer. A distinct and wonderful flower. \$1.00.

197-UADAVE DE VATRY (Guerin, 1S63)-Verv large finely formed bloom; lilac-white guards and crown; sulphur-white collar of wide petals, center striped carmine. Superb. 75 cents.

16-MADAME DE IERNEVILLE (Croussc, 18S5)One of the most charming varieties on the market. Pure white, full and doublc. Extra. 60c. 


\section{THE CREAM OF THE PEONIES-Concluded}

101-MADAME DUCEL (Mechin, 1880)-This is such a perfect shape and is such a silvery-pink color s to resemble a Chrysanthemum flower. Those who know the variety Monsieur Jules Elie will immediately know this variety. It is identical in color and shape with that famous variety, but it is one week later in blooming and one-third smaller in size. \$1.00.

7-MADAME EMILE GALLE (Crousse, 1881)Color delicate sea-shell pink with touches of the beauty of this wonderful flower. \$1.00.

32-IADAME FOREI. (Crousse, 1851)-Enormous very full double blossoms of deep pink, known as the "Princess of Pinl Peonies." \$1.00.

22.5-MADAME LEBON (Calot, 1853)-Large full blooms of cherry-red tinged aniline. Very showy. bo cents.

250-MADAME MECHIN-Deep crimson-garnet, a glorious Peony of great merit. \$1.00.

136-UADAUE THOUVENIN (Crousse, 1881)-Brilliant rosy-red flushed carmine and lilac; large globular flower. 75 cents.

169-MADENOISELLE DNSBCISSONS (Crousse 1893) - Very large, full, elegantly shaped bloom; imbricated and flat extra large petals: color tender glossy pink, center of waxy-white; guards violet-rose. So cents.

15-UA DEVOISELLE LEONTE CALOT-One of the grandest of all Peonies, almost hides the plant with its wonderful free blooming qualities: delicate rose-white with soft lilac-pink center. Exquisitely superb. \$1.00.

1S-MADEHOISELTE ROUSSEAU (Crousse, 1886) -Large, full. finely shaped flowers. Primary petals milk-white, prominently splashed carmine central petals sulphur-white with slight blush tinge. $\$ 1.25$

39-MARECHAL VALLIANT (Calot, 1867)-Immense globes of light red with shades of mauve At Chicago show in 1905 it won the first prize for best red. 75 cents.

429-MARIE HOUILLON (Cal., 1869)-Large, compact, globular, rose type. Light violet-rose with silver reflex, cup-shaped center fracrant: medium height, good habit, free bloomer. Late. \$1.25.

130-MARIE JACQUIN (Verdier) - At first it comes single, after the plant gets older it doubles up. Suggests the water lily. A delicate blush color. changing to pure white. \$1.00.

10-MAREE STUAR' (Calot, 1856) - A delicate lavender, the one prettiest Peony in our list. 75 cents.

216-MASTERPIECE (Kelway, 1895)-Semi-rose type; early. Brilliant tyrian-rose; free bloomer. A very distinct and beautiful variety. Fine, tall grower; fragrant. \$1.00.

151-MATHILDE DE ROSENECK (Crousse, 1883)Soft flesh-pink, shading deeper toward the center with tinting of lilac and chamois. Very late bloomer. \$1.25.

35-HEISSONIER (Crousse, 1886)-Very brilliant crimson, full double flowers on stiff stems. A fine cut flower variety. 60 cents.

152-MODELE DE PERFECTION (Crousse. 1875)A most glorious flower; guards and collar light rose with shades of flesh-pink. A wonderful combination of colors. \$1.00.

158-MODESTE GCERIN (Guerin, 1845) - Large handsome, globular bloom; color a uniform solferino-pink, tinged carmine. Has the true fragrance of the American Beauty Rose. \$1.25.

153-MONSIEUR DIPONT (Calot, 1872)-Very large blooms of ivory-white with large irregular blotches of carmine on the petals. A truly royal flower. \$1.25.

48-1 IONSIFUR JUI.ES ELIE (Crousse, 1888)This is the king of all Peonies, and is without question M. Crousse's masterpiece. Immense globular, very full flowers. Color an ideal glossy lilac-pink, shading to deeper rose at the base, the entire flower overlaid with a sheen of silver that fairly shimmers in the sunlight. \$1.00.

61-Ne PLUS ULTRA (Miellez, 1856)-Color light violet-rose with silver reflex and salmon-pink. so cents.

169-PILLOMELE (Calot, 1861)-Guarảs bright rose, anemone center of lingulated narrow goldenyellow petals, changing to cream or amber-yellow. This is a very beautiful sort; has the true honey fragrance. \$1.00.

F1-IRESIDENT IROOSEVELT (Holland, 1905)It is a deep rich brilliant red of the brightest hue. A good Peony. \$1.50.

50-PRINCESS BEATRICE (Kelway, 1886)-Guards delicate lilac, crown of brilliant sea-shell pink; a glorious flower. \$1.00.

42-IURPUIEA SUPERBA (Delachei, 1855) Go cents.

A0-QUEEN VIC'TORIA (Whitley, 1808)-The very best everyday white, flowers of good substance and lieep a long while. 50 cents.

49-IR ACHEL (Terry)-One of Terry's really good varieties. Brightest garnet-red shaded richest ruby-red; almost smothers itself in bloom. \$1.0i.

321-HOSE d'AMOUIR (Calot, 1857)-Bomb type Early midseason; Hydrangea-pink; fragrant and fine; very large. 50 cents.

145-RUTENS (Delachei, 1854)-Very dark crimson with prominent guards; a charming Peony. cents.

78-RUHRA SUPERBA (Richardson, 1871)-Mag nificent rich brilliant deep crimson without stamens. Very large, full and double and very late: always come perfect blooms. Very free bloomer. The past year it bore more bloom than any other variety we had. \$1.00.

165-SARAH BERNHARDT, "The Divine Sarah" (Lemoine, 1906)-Flowers of remarkable size and freshness in huge clusters, full and double. of unusual perfection of form; extremely large petals that are imbricated, twisted and limbriated; color apple-blossom pink with each petal silver tipped, giving the appearance of a distinet bordel of pure white; fragrance agreeable and penetrating; magnificent. Easily scores the six points of excellence. $\$ 4.00$.

50-SIMON NE CHWVALIER (Dessert, 1902)-Very large globular flower. Pale lilac-rose tinged salmon-pink, bordered with silver. \$1.50.

337-THE HRIDE ('Terry)-Lilac-white guards and milk-white center; extra good variety. \$1.00.

77-THE LORD KITCHENER (Renault, 1915)-A most beautiful flower, brilliant cherry-red, very free and said to come early. \$4.00.

181-TRIOMPHE DE 1'EXPOSITION DE LILLE (Calot, 1865)-Huge pyramidal effect in form that is seen in but few Peony flowers. Lalge compact bloom of a fresh hydrangea-pink splashed with darker tints of violet-rose. Grand. \$1.00.

313-TRIOMPH DU NORD (Miellez, 1850)-Bom h type; midseason. Light carnation-pink, much the shade of Enchantress Carnation Fragrance. bo cents.

322-VAN DYCK (Crousse, 1879)-Guards and center true Enchantress pink; extra fine. 75 cents.

210-WELCOME GULST (Hollis, 1904)-Large, loose flowers of uniform glossy silvery-pink, changing to rose-white. Flagrant, erect, tall, strong grower. Free bloomer. \$1.50.

172_ZOE CALOT (Miellez, 1855)-Rose type; midseason. Very large, globular bloom. Color soft pink shaded lilac; free bloomer. 50 centw. 


\section{TENDER PLANTS}

\section{PLANTS IN THIS LIST WILL NOT STAND THE FROST \\ Abelia Grandiflora \\ Cestrum}

This is one of the prettiest of all shrubs. Has small shiny leaves like they were glazed. Bears its bell-shaped pure white flowers in the greatest profusion all summer long, deliciously fragrant. Hardy south of Kentucky. Much sought after where it is known. We would advise our customers in the South to plant this shrub for hedges. 30c each; \$25.00 per hundred.

\section{Asparagus Plumosus Nanus \\ The Lace Fern}

This graceful climber has to a great extent taken the place of the once popular Smilax in all fine decoration. It possesses the advantage of being much more graceful-its foliage being finer than that of the most delicate Fern-and it will last for weeks after being cut, the whole plant being of a bright, cheerful green. Excellent house plants succeeding under almost any conditions; by pinching back may be grown as a plant. 15 cents each for line plants; large, strong plants, 50 cents each.

\section{Asparagus Sprengeri}

The Emerald Feather Fern

A most desirable species, especially useful to.grow s a pot plant for decorative purposes or for planting in baskets or vases. Fronds are frequently four feet long, of a rich shade of green, and most useful for cutting, retaining their freshness for weeks after being cut. It will make an excellent house plant, as it withstands dry atmosphere and will succeed in almost any situation.15c each, 3 for 50e; strong plants, 40c.

\section{Flowering Begonias}

These Begonias are fine for house culture, as all ill flower during the dark days of winter. Price, except where moted, 30 cents each; four priced at 30 cents for $\$ 1.00$.

ALBA PICTA-Long, pointed, slender leaves, thickly spotted silvery-white; foliage small, elegant; lovely pink flowers.

ARENTEA GUT'ATA-Lovely green foliage, with spots of silvery-white.

CORALLIN LUCWRNE, the Wonderful New Flowering Begonia- This new Begonia has simply taken everybody who has seen it by storm. There was not a single lady or florist who visited our greenhouses the past spring that did not purchase this Begonia after they had seen it in flower. It certainly is a wonder. The blooms last from a month to six weeks, and are borne in immense clusters, almost hiding the plant. The color is bright coral-red, changing to a delicate pink. It is past the power of speech to describe it. A wonder. Fine plants, 5o cents.

PiCTA RosEA-Bright, silvery-pink flowers. Extra fine.

PRESIDENT CARNOT-Upper side of foliage deep green, under side blush-red; flowers beautiful coral-red.

RUBRA-Strong, slender branches drooping under heary waxen leaves and pendent panicles of coral-colored flowers as large as a hand. Medium sized plants are frequently seen with more than twenty such panicles at a time. 40 cents.

ANDERsoxil (The Coral Begonia) - One of the best flowering Begonias. Flowers of a scarlet shade of crimson, borne in profusion for months at a time. Resembles coral.

TIIURSTONII-Metallic-green leaves, shell-pink

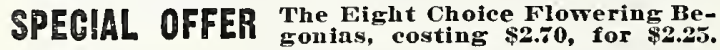

\section{Brugmansia, or Angel's Trumpet}

Here is a plant for the masses. It grows easily, blooms freely, and the flower is something to be proud of. The Brugmansia blooms indoors in winter and in the garden in suinmer. The plant has large, typical leaves, with blooms eight inches long by six inches wide at the "mouth, resembling a trumpet, hence the name "Angel's Trumpet. Pure white in color a
(Night Blooming Jasnine.) A much esteemed summer bedding plant, with waxy dark green leaves and open panicles of tubular, creamy white flowers. Although inodorous during the day, they flll the whole garden with fragrance at night. 25 cents eacl.

\section{New Giant Coleus, Christmas Gem}

\section{(Brilliancy, or Dr. Ross)}

Leaves immense, eight to twelve inches long, looks like a Rex Begonia, and is just as beautiful. Cannot be excelled as a pot plant. The name aptly describes the appearance of this variety, which belongs to the giant-leaved section; of strong, vigorous habit, growing from two to three feet high, with leaves often nine to ten inches long, which are of bright carmine, shading off to a deep maroon, the margin being yellow and green, the whole leaf having a rich velvety luster. 25 each; three for 65 cents.

THE WONDERFUL NEW COLEUS,

\section{Trailing Queen and Trailing Beauty}

These Coleus are an entirely new break, as no one ever before heard of a Coleus that trailed. They both have glorious foliage-The Queen having a large distinct center of bright pink or red, with a broad border of emerald-green. In The Beauty, the foliage is a rich golden-yellow, often changing to pure white. No plants are more suitable or showy for hanging baskets, window boxes, vases or pot culture than are these two trailing Coleus. Put several plants in a basket or pot and see how lovely a plant may become. 20 cents each; the two for 35 cents.

\section{Coleus-General Assortment}

These are all good bedders, standing the hot sun without losing their color, 12 cents each, ten for $\$ 1.00$; the entire twenty-two varieties for $\$ 2.00$.

ACME-Bronze, red center, edged green.

ADMiRATION - Deep claret-red, edged green and yellow.

BEAUTY - Rose center bordered with dark red; green border.

BECKIVITH GEM-Dark velvety maroon, bordered fiery-red, edged green.

CHICAGO BEDDER-Yellow, mixed with pea-green. COUNT CUVIER-Center fiery-red, surrounded with deep maroon, edged olive-green, serrated edge.

DUNERIA-Grandest Coleus of recent year; has a deep velvety texture. Color crimson, maroon center; beautifully scalloped edge of light red; a fine showy bedder

EMPRESS OF INDIA - Bronze-red, golden-yellow edore.

FIREBRAND-Brilliant dark red; extra.

FIRECREST-Carmine-crimson, bordered scarlet. GOLD BoUND-Dark maroon with blotches of a darker shading; yellow border.

HERO-Very dark, almost jet black.

JOSEPH'S COAT-An intermingling of many colors

MAY LEVEIRIG - Spotted and striped with ma-

roon, green, red and yellow. green, margin bright yellow.

QUEEN VICTORIA-Yellow and bronzy-red.

RED CLOUD-Dark red of royal hue.

SENSATION-Crimson-maroon, center bright red.

SETTIXG SUN - V e l ve t $y$ red, bordered goldenyellow.

SPOTRED GEM-Spotted yellow, green and red.

VERSCHAFFELTI-A rich velvety crimson.

YELLOW HIRD-Clear bright yellow.

\section{Fuchsias, or Ladies' Eardrops}

Price, 20 cents; six for $\$ 1.00$.

BLACK PRINCE - This is, without question, the very finest Fuchsia grown for the amateur to cultivate. It makes a shapely bush, is robust in growth, free from disease and insects, and is probably the freest in blooming. We have seen specimen plants six feet in height and four feet across loaded with thousands of bright buds and blossoms of a beautiful waxy carmine or pink color. Certainly a plant of easy culture, 


\section{General Collection of Tender Plants-Continued}

Fuchsias, or Ladies Eardrops-Concluded

ERNEST RENAN - White se pals, reddish-blue corolla.

LITTLE BEAUTY - Red sepals, sky-blue corolla, so free as to almost hide the plant.

LORD BYRON-Red sepals, corolla of the richest royal purple, so free in flower as to almost hide the plant.

MADAME VAN DER STRASS-This is the best of the double white corollaed Fuchsias.

SPECIOSA - Habit erect and compact, presenting a decidedly neat and attractive appearance as a jpot plant, the fine star-shaped flowers are produced in profusion, and begin when plants are quite young. The flowers are three inches or more in length; tube and sepals bright rose, oorolla brilliant carmine; it blooms quite freely.

ATENOR-Red sepals, double purple corolla.

\section{Chinese Hibiscus}

25e each. We have large plants of Hibiscus, ready to bloom, for 50e each. These are handsome plants.

SINEVSIS GIGANTEA-This is a plant for house cultivation diring winter or summer, or for planting outside during summer. It blooms at all times of the year. The plants branch freely and finower profusely, commencing to bloom when not more than a foot high. As a specimen plant for large pots it has an equal only in the Brugmansia. Its lowers are of enormous size, often eight to teu inches across, opening flat, and of such vivid crimson-scarlet color that they can be seen from a long distance like a flaming torch. They can be wintered in the cellar or pit with perfect safety, and if one does not care to grow them all winter one should have one or two for summer display.

GRANDIFLORIS-Rỉch, glossy, cut-leaved foliage, literally covering the plant with scarlet-crimson flowers.

SUBVIOL.ACEOUS-Flowers of enormous size, beautiful carmine, tinted with violet. Probably the largest flower of the Hibiscus family, and an unusually free bloomer. We take pleasure in recommending this fine plant.

DOEBLE CRIMSON - This grand variety has imnense flowers of the richest crimson; combined witl glossy foliage, renders it best of all.

AURANTIACS-Large and double, with orangecolored flowers.

CARMINIATUS PERFEC'TUS - Full, round flowers of perfect shape and of a rich, soft, carmine-rose, with a deep crimson eye; fully six inches in diameter.

VERSICOLOR - A variety combining in its flowers all the colors of the whole family, being handsomely striped crimson, buff, rose and white. Flowers eight inches in diameter.

SPECIAL OFFER-IVe will send the entire set of isteven distinct hinds of Hibisens for $\$ 1.50$.

\section{New Pink Hibiscus, Peachblow}

(A sport from the Double Red Hibiscus Rosea sherasis.) The flowers are double and from 4 to inches in diameter, of a charming, rich, clear pink color, with small, deep crimson center. It is one o the frest-flowering plant novelties recently offered. The color is an entirely new and beautiful shade, :ane it blooms abundantly and continuously during the summer and fall months. Large plants two and th ree years old make a magnificent show. It will give general satisfaction to those who grow it, either in pots or planted out in the garden. It blooms well in the winter in the greenhouse or in any sunny window. Price, 35 cents each; strong. fine plants, 60 cents each.

\section{Wonderful New Lemon, Ponderosa}

Nothing that has ever been brought to our notice in the plant line has caused half the commotion that this wonderful lemon has. It is a true everbearing variety on a plant six feet high no less than 89 of the Ponderosa Lemons were growing at one time. It was a beautiful sight to see. The tree was blooming, and even at the same time had fruit in all stages of development, from the size of a pea up to the ripe fruit, showing it to be a true everbearer. Fruit has been taken from this tree weighing over four pounds. The Lemons have very thin rind for such large fruit. It is the juiciest of all Lemons, makes delicious lemonade, and for culinary purposes cannot be excelled. It is not uncommon to make twelve lemon pies from one lemon. We have the entire stock of this ponderous lemon and guarantee the trees to produce the same large fruit. No budding or grafting necessary. Ponderosa Lemon is sure to become popular when it is known... It fruits when quite small, and makes a lovely house plant. Everybody can grow his own lemons; it will fruit freely each year. Thrifty young plants. 2.5 cents each. Larger plants, 50 cents. Extra strong, \%5 cents.

\section{Standard Sorts of Dwarf Lantanas}

Price, 20 cents ench; the six for $\$ 1.00$.

ALBA PERRECTA-Pure white.

COUNTESSE DH BIGNCOURT-Clear, bright pink.

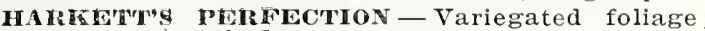
cream and pink flowers.

JAUNE d'OR-Cream and orange.

LEO DEX-Rich red.

M. SCHMIDT-Orange-scarlet.

\section{Dwarf Lantana Tethys}

Try our Dwarf Lantana "Tethys." It is fine for. bordering beds, a splendid lemon-yellow. Price; 20 cents each.

\section{Weeping Lantana}

A Weeping Plant of Great Beauty. One of the grandest basket plants grown. The plant has most graceful, drooping habit, grows very rapidly and blooms continually summer and winter, producing large clusters of the most delicate lilac or rosy-pink. Price, 20 cents each; 3 for 50 cents,

\section{Otaheite Orange}

This valuable and distinct variety of the Orange family is a dwarf, compact grower, with glossy, deep green foliage, which has a decided odor of the Orange trees of Florida, and is exceedingly floriferous, producing a wonderful profusion of pure white flowers of the most delicious fragrance. Otaheite fruits immediately after flowering, bearing fruit about one-half the size of the ordinary Orange, retaining in a marked degree its sweetness. This unique Orange cannot be equaled as a winterblooming pot plant for house culture. Requires but little sunlight, and flowers and fruits when but twelve to tifteen inches high. With a couple of plants of it you can have an abundance of the farfamed and delicate Orange blossoms. We have grown a large stock of clean, vigorous plants that will bloom and fruit at once. Good plants, 25 cents ench: large, strong plants, 50 cents, 75 cents and $\$ 1.25$ each, aceordiug to size.

\section{Pansies}

In the South fall is the time to plant Pansies for best results. Our Pansies are the best the world produces. They combine the choicest large-flowered sorts, both of European and American growers. It has been our aim to make this the finest strain of this favorite flower in existence. Six for $\mathbf{2 5}$ cents; 40 cents per dozen; $\$ 3.00$ per 100 . Seeds, 15 ceuts per packet.

\section{Pilea}

(Artillery Plant.) It is very desirable for fllling in hanging baskets, window boxes, vases, etc. It also makes a graceful planti as a single specimen. It has graceful frond-like leaves; flowers small and produce a snapping sound when water is thrown on the foliage. Price, 15 cents each; two for 25 cents.

\section{Chinese Primrose}

These are grand winter-blooming plants. We haye three colors, White, Pink and Red. 25 cents 


\section{General Collection of Tender Plants-Concluded}

\section{Baby Primrose "Malacoides"}

(New Everblooming.) This is the freest-blooming plant we know of, blooming continuously during the entire season. Plants in very small pots have from fifteen to twenty splays of beautiful irght pink time. 20 cents each.

\section{Primula Obconica}

Free-blooming plant. Fine for pot culture. We have white, pink and red. zo cents eaeh; three for 50 cents.

\section{Ruellia Mokoyana}

This is a charming indoor plant for culture in pots or may be used in vases and baskets; of bushy spreading habit and finely marked leaves, which are beautiful olive-green, delicately veined with silver and rich purple underneath. A neat and handsome plant, always bright and pretty. The flowers are exceedingly beautiful, trumpet shaped, and of a rosy-lavender color, almost covering the plant in their great profusion, 20e each; i for sue.

\section{Sanseviera Zeylonica, Zebra Plant}

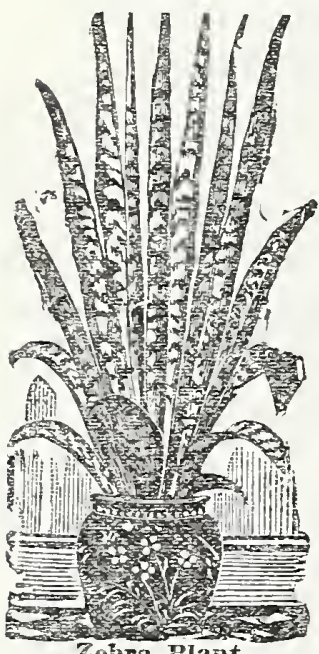

A beautiful plant, specially adapted for the decoration of drawing rooms and lialls, as it stands dust and drought with impunity and requires scarcely any water. The leaves are beautifully striped crosswise. with broad white variegations on a green ground. It is a rare and beautiful plant, which should be abundantly grown for positions out of the reach of sunshine, where other plants will not thrive. It can be placed in any position in any room and do well. It has singular beauty for decorative purposes which other plants do not possess, and it is useful both in winter and summer. For vases and basliets it is a fine center piece, and grows splendidly out of doors during summer. Fine plants, 25 cents.

\section{Violets}

IPINCESS OF WALES-This is the best of the Single Violets. True Violet-blue; fine for cutting. 15 cents each.

LADY HUIE CAMPBELE-One of the best of the double purple violets; better than Marie Louise. 15 cents each; $\$ 10.00$ per hundred.

SWANLEY WHITE-Double white flowers in great profusion. IJ cents each.

NEW IMPERMA, or PARMA VIOLET-This is, without question, the largest, richest colored and most highly perfumed of all the single flowering Violets. It blooms very freely, literally bending the plant with its lovely blue flowers of the largest size. Its blossoming season is longer than any other violet. 25 cents.

\section{Tritoma Pfitzern}

(Red Hot Poker.) An improved upstanding type of perfect form: brilliant scarlet, the opened lower petals merely being rimmed with orange. Rushlike foliage supports smooth, thick flower stalks a yard long, with a single fiery cone at the top. July September. Must be carefully protected or else carried dormant in dry sand in the cool cellar during winter. 40 cents each; three for $\$ 1.00$.

\section{GENERAL LIST}

In this list we do not give extended descriptions, but our customers will find many valuable plants embraced. These are suitable for house and garden culture.

Each

ACAIIPHA SANDERI-The Comet plant..... 20c

ACAL YPHA TRICOLOR-Fine bedding plant... 20c ACALYPHA TRIUMPHAS-Gorgeous foliage,

fine bedder ..................... $20 \mathrm{c}$

MOYSIA CITRIODORA-LEUON VERBEIA-

The most fragrant foliage of any plant..... soe BROWALLIA GIGANTEA-Flowers intense in-

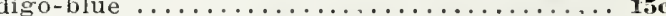

CRAPE MYRTLE-Three colors, pink, crimson

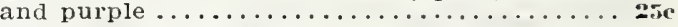

CUPHEA PLATTCENTRA, or Cisar Plant.... 15e CYPERT ALTER SIFOLIUS, the Umbrella Plant

-A handsome pot plant, useful in rases, etc. 20e EUPHORBIA SPLENDENS, or Crown of Thorns 25c HIDRANGEA OTAKSA-White flowers....... 25c IMPAEIENS, or SULTANI-Six distinct color's.

(Six for $\$ 1.00) \ldots \ldots \ldots \ldots \ldots \ldots \ldots \ldots \ldots \ldots$

IVRTLE, SWEET, the Jew or Bride's Mrrte-

The leaves are very fragrant................ PI.UMBAGO CAPENSIS-Sky-blue flowers..... 2ac PETUNAS-Double flowering; fou $\mathrm{r}$ colors.

Four for 75 cents) .................. 20c

SALVIA SPLENDENS-Brilliant scarlet...... 10e SALVIA LE PRESIDENT-Rich scarlet flowers. 10e SALYLA SPLENDENS ALBA-Pure white..... I0 SALVIA MRS. PAGE-A perfect sheet of scarlet $10 \mathrm{c}$ (Salvias, \$1.00 per (lozen)

SAXIFRAGA SARMENTOSA, or Strawberry

Geranium , ir............ ii colors

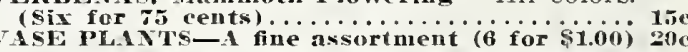

\section{TENDER VINES AND CLIMBERS}

These make a rapid growth and bloom throughout the summer; are very showy.

Wlac Woxderful Giant Moonflower, IPOMEA MAXIMA - I Gint in Grobth and Flower and Wonderfully Fragraut. This grand new Moonflower is a decided improvement over the old well-known variety Ipomea Grandiflora. The flowers are more than twice the size of the old variety oftentimes measuring from six to seven and one-half inches across, and are produced in such wonderful profusion that they completely cover the vine with a veil of glistening white. Fine plants, wo cents eaciz.

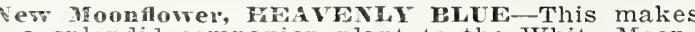
a splendid companion plant to the White Moonflower. It is equally rapid in growth, and a much freer blooming variety than the white one. The blooms come in clusters of five to twelve, and at times almost hide the vines. The flowers are the most heavenly blue, WIth reddish-purple rays, and
six inches across. Nothing is nore beautiful. ar) cents.
ANTIGXON LEPTOP'LS, or the "Queen's Wreath"Produces rose-colored flowers in racemes two feet long; beautiful. 20 cents.

BOCGAINILLEA SANDERIANA-The Ch inese Paper Plant. Lovely clear lavender flowers. 35e.

PARLOR IVY-A rapid-growing plant, well adapted for training in the parlox. Leares glossy greell and flowers vellow, in clusters. 12 cents each.

MADEIRA VINE-White flowers: exquisitely fragrant. 10 cents each: three for 25 cents.

SMILAX-A lovely house vine, 10 cents.

TRIDESCANTIA, or WANDERING JEW:-Fine for baskets. Two distinct kinds. 15 cents each.

VINCA MAJOR VARIEGAT-Fine for baskets and vases: green and white foliage. 20 cents; large, strong blants, 50 cents. 


\section{TENDER BULBS}

\section{Amaryllis}

AMARYLLIS FORMOSESBMA-Flowers are rich, dark scarlet. 25 ecnts.

AMARYLLIS EQUESTra (The Engle Lily)-Color deep brick-red; extra fine. 25 cents.

A.MARVLTIS JoHsSovit - Lovely bulbous plants for winetr or early spring blooming. Give plenty of water while growing. When through blooming, gradually withhold water, so that they may become dormant through the summer. Start again in the fall by repotting in fresh soil and increasing the supply of water' gradually. This is the large crimson variety that is very popular. Inmense lily-like flowers of deep crimson, borne on strong stalks of from five to eight flowers. Very desirable. Fine bulbs, 50 eents each.

\section{Amaryllis Hybrids}

We are lucky to get a lot of English Hybrid Amaryllis. We guarantee these to be the very best of all Amaryllis, in fact you have never seen anything to match them. Colors run largely to shades of red. Any color' you get will be glorious. While they last, fine large inhlos at 50 cents each, or three for $\$ 1.25$

\section{Cyclamen Periscum}

(or Persian Violet.) Fine for house culture: blooming in the winter. 25 cents.

\section{Milk and Wine Lily}

(Crinum Fimbriatum.) "I must tell you that Milk and Wine Lily has done famous work. It has developed nine fine blooms, and there are two unopened buds. We, therefore, gave it a free ride last Wednesday to our chapel services. It was admired by ererybody. There were Bostonians and people from various towns to admire and enjoy it."-Mrs. E. Adams, Mass. A grant sort. The most beautiful of the Crinums. Its bulbs grow large, and its strong-growing foliage is erect and sword-shaped, flowers in umbels, very large and showy, three to four inches in diameter, striped with white and carmine, and very fragrant. Fine buhbs, 50e eneh.

REMENBCR-Oar Gladioli nre the finest in the market and will be sure to please.

DON'T FORGET-When in need of Peonies, consult onr "leonies for loleasure," sent for the asking.

\section{Calla Lilies}

Evergbody Needs a Calla for Vinder Blooming. Hite are the IRest.

CAFUA ETHYPICA - The old-fashioned sorts in three sizes. Small bullos that will bloom, 25e each large bulbs, 40e cach; extrat large bulhs, 75e eacls. THE GODFREY CALLA LILY, "HeVOHIergis"-Un doubtedly the finest thing ever sent out in th Calla line, and quite indispensable. Blooms winter. Compared with the ordinary Calla, gives three blooms to one; it is snow-white ane perfect in form. Blooms on very small plants though it attains to a very large size with ver. large flowers. The new Godfrey Calla Devonien-

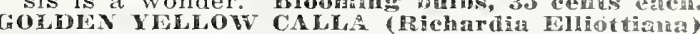
-Entirely distinct and unlike all other forms of yellow Calla; it has the same habit of growth as the ordinary white variety, with flowers of same size and shape, but of a rich, clear, lustrous golden-yellow color; the foliage is dark green with a number of translucent creamy-white spots, which add much to its beauty. It is but a few year's ago that this sold at a very high

We are now able to offer strong, blooming bulbs at 10 eents each; two for $\$ 1.50$.

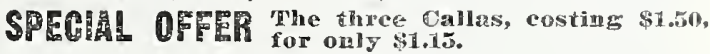

\section{Spider Lily}

This is one of the prettiest and daintiest of all Lilies. It is pure white with bands of a greenish color through the flower; this green and the white make a charming combination that everyone admires. The filaments and stamens of this choice Lily resemble a liuge spider; not repulsive, but the most beautiful and delicate of all lifies. Eack, 40e; three for $\$ 1.00$.

\section{Lily of the Valley}

The modest bell-shaped flowers, of the purest white, are highly prized for cutting purposes, and for flowering in pots in winter they are exceedingly well adapted. Beautiful and most interesting ornamental designs for the parlor or conservatory ma be produced by planting lily crowns in Crocus pots or in pyramidal pots made especially for this purpose and pierced with holes. They will last several weeks in beauty. By taking them in at intervals a succession of different designs may be kept up all winter. They are also forced in immense quantities by florists, but they are the most charming when grown in large patches in partially shaded localities around the lawn, near the borders of streams, lakes, etc., being perfectly hardy. I'rice, \& cents each; 40 cents ber dozen; 25 ior 750 .

\section{HARDY VINES A}

THE WONDERFUL

Japanese Kudzu Vine

(Jack and the Bean Stalk Vine)

This is the most rapid-growing vine that anyone knows of. By measurement it has been known to grow twenty feet in a week. The foliage is large and tropical. It is entirely hardy. Everyone has trouble in getting nur'sery-grown plants of this to grow. TVe have prepared and offer pot grown plants, the kind that have the crown to the plant and ball of earth to the roots, and you try to stop them growing and see if you don't run into a snag. This is proving a great forage plant in the south All kinds of stock prefer it to hay o1 other common feed. Try it. 35 cents each; three for 85 cents.

\section{Cinnamon Vine}

Bears white flowers with fine cinnamon fragrance. 10 cents caeln; three for 25 cents.

\section{Chinese Wisteria}

Desirable for porches, trellises, etc., and when in full bloom is truly magnificent. It flowers in early spring, in long, drooping racemes, resembling in size and shape a bunch of grapes. 25 cents; large plants, 50 eents.

\section{Ampelopsis Veitchii}

(The Boston rys)

Clings firmly to any wall, building or tree. Green leaves in summer, changing to red in the fall. $\mathbf{2 5}$ cents cach; two-year piants, 50 cents.

\section{AND CLMBERS}

\section{Hardy English Ivy}

Evergreen, with dark, glossy green leaves. 85 cents each.

\section{Clematis Paniculata}

Covered in August and September with a sheet of clustered snow-white bloom of the most delicious fragrance. An arbor or portico over which this Clematis is trained is a wall of white for the time being, and it blooms when nearly all other vines have ceased blooming. Perfectly hardy;
grows rapidly. Fine roots, 20 cents, thee for so cents. Strong two-vear fiels plants to bloon this year, 40 cents.

\section{Honeysuckles}

ITREA RETICTLATA (Golben LenFed)-A variety with beautiful variegated foliage of yellow, white and pink. 20 cents.

CIIYESE WVERGPEN-Sweet-scented. Blooms nearly all the season; deliciously fragrant; flowers buff, yellow and white. zo cents.

HALL'S JAPAN-Sweet-scented. This is the most consistent bloomer of the class, being litelally covered all summer with beautiful yellow and white flowers; very fragrant. 20 cents.

SCARLET TRUMPL'T, or IRED CORAL - A rapid grower, bright red with trumpet-shaped flowers. This is the old, well-known variety, 20 cents.

YELLOW 'TRUMPET-G o l d e $n$, trumpet-shaped flowers; fragrant. 25 cents.

The set of Five Honeysuckles for $\$ 1.00$. 


\section{HARDY PERENNIALS FOR THE BORDER}

AQULEGIA COLUIRIVE-Assorted colors, Height two feet. 15 cents each; $\$ 1.50$ dozen.

ACHILLEA, THE PEARL-Pure white flowers in immense clusters; fine for cemetery planting. Height two feet. 15 cents; \$1.50 dozen.

CAMPANULA, CANTERIURT FELL - These imposing hardy plants are profusely covered with large bell shaped flowers. Extremely showy in shrubberies and mixed borders. Height three feet. 20 cents.

COREOPSIS LANCEOLOTA GPANDIFLORA-Golden-yellow, invaluable for cutting. Height three feet. 15 cents.

DIGITALIS (Forglove)-Gloxinia-like flowers; flne assorted colors. 15 cents; $\$ 1.50$ dozen.

DAISIES, BUIBANK'S SIAS'T-The Shasta Daisy is one of the most marvelous productions in the flower line that has ever been brought to the notice of floriculturists. It is the first of a new type which has been obtained by hybridization and rigid selection through a series of years. Its first qualification is extreme hardiness. Second. it is perennial, blooming better and more abundantly each season. Third, it is not particular as to soil. Fourth, it blooms for several months. Fifth, the flowers are extremely large and graceful, averaging about four inches in diameter, with petals of the purest glistening whiteness, which are borne on single, long, stiff, wiry stems. Sixth, the blooms when cut remain perfectly fresh and in good condition for two weeks or more. No other flower can compare with it in usefulness. We have two kinds of shasta Daisies, FING EDWARD and ALASKA. Height two and onehalf feet. 20 cents; $\$ 2.00$ dozen.

EULALIA JAPONICA ZEBHINA (Iardy Grass)Striped across the leaves. Fine plume. 20 cents; \$2.00 dozen.

EULALIA JAPONTCA VARIEGATA (Hardy Grass) - Striped white and green; bears elegant plumes. 20 cents; $\$ 200$ droen.

EULALIA GRACILIS UNIVITTATA (Hardy Grass) - Makes immense clumps. Very graceful. 20 cents: $\$ 2.00$ dozcn.

\section{Platycodon}

The upright Clematis. Both blue and whiteflowering. Height two and one-half feet. 20 cents.

\section{Plumbago Larpentae}

(Or Lady Iarpent.) Deep royal-blue flowers. This is an elegant plant. 15 cents.

\section{Hardy Scotch or Sweet May Pinks}

These are the Pinks of our mothers gardens; a.11 colors. 15 cents each.

\section{New Hardy Scotch Pink "Her Majesty"}

Pure white flowers; flne for cemetery planting. 15 cents each; three for 35 cents.

\section{Sage}

(Holt's Mammoth.) A variety of unusual sub-
DELPHINIUT OR LARIKSPIR - Indispensable to the herbaceous garden, their long, showy spikes of flowers persist from June till frost and furnish the most satisfactory blues to any color scheme. Height two to three feet.

DELPHINUM, BELLA DONNA-Pure sky-blue; White bee; fine for cutting. 30 cents each; $\$ 25.00$ per handred.

DELPHINUM, FORMOSUM-A lovely celestial blue. 30 cents each; $\$ 25.00$ per hundred.

\section{Funkias "Day Lilies"}

FUNKIA MEDio VARIEGATA-Green and white foliage with lavender flowers, 25 cents.

FUNKIA "SEB-CORDATA" (Granditiora Olla-A handsome, showy plant with beautiful large broad leaves. Flowers large, pure waxy-white, borne in large trusses. Very fragrant. 35 cents each.

GYPSOPHILA (Paniculata) - Delicate free-flowering little plants, covered with a profusion of starshaped blossoms. It is perfectly hardy. Price. 35 cents each.

GAILLARDEA GRANDIFLORA (Blanket Flower)The center is dark red-brown, petals marked with rings of brilliant crimson-orange and vermilion 30 cents.

HEMEROCALLIS FLAVA (The Lemon Lily)-This is entirely hardy and bears flowers of a lemonellow color. Very desirable. 20 cents.

HIBISCUS CRTISON EYE-Belongs to the family of Mallows. Flowers six inches across. Color pure white with pronounced eye of deep crimson. 25 cents.

VAIERIANA (Garden Heliotrope)-The Valerianas are hardy perennials of easiest culture. This is one of the characteristic plants of old gardens, being prized for the spicy fragrance of its numerous flowers in the spring. Have both the white and the red. 20 cents cach.

NEIV GLANT HALLOW MARVELS (Red Marvels)An improved perennial. A hardy plant, suitable for damp locations. Price, 25 cents each.

\section{Pyrethrum Hybridum}

(Persian Daiss.) These are very handsome showy flowers. Is known as the Daisy-flowering Feverfew or Persian Daisy. Height two feet. 20e.

\section{Rudbeckia Laciniata}

(Golden GIow.) Grows six to eight feet bigh. bearing hundreds of double yellow blossoms. Very desirable. 20 cents.

\section{Stokesia Cyanea}

(or Cornflower Aster.) Grows 18 to 24 inches high, flowers lavender-blue; four to five inches in diameter, borne from June to October. 20 cents.

\section{Yucca Filamentosa}

(Spanish Dagger.) Blooms every year, bearing long stalks surmounted with large umbels or heads of white flowers. $\mathbf{2 5}$ cents.

\section{HARDY DECIDUOUS SHRUBS}

Whether planted individually or collectively Shrubs are an important feature in the adornment of any yard. The rich green of the summer foliage plays a greater part in landscape effect than is csten

The Ever Bloom planting herally or shrubs.

\section{The Ever-Blooming Butterfly Bush}

Buddleya Variabilis Magnifica (Butterfty Bush).

It was a matter of some thought before this the common English name by which it goes. Several years ago there were imported from Europe some plant novelties and this one was among them. We observed it carefully for a season and were charmed with its beauty, ease of culture and free flowering habit. The name Butterfly Bush was applied to it because it seems to attract butterflies in large numbers. Particularly we notice that it is not alone the common little yellow species of butterfly, but also the large and gorgeously colored hutterflies that swarm about it as though vieing with it in brilliancy of color. This shrub from a young plant set out either in the spring or fall, will mature to full size the first summer, producing a handsome bush, which the first year often maintains a height of four feet. It produces long, grace- ful stems, which terminate in tapering panieles of beautiful lilac-colored flowers that are of miniature size and borne by the hundreds on a flower head which is frequently ten inches long. A single plant the first season will throw out as many as fifty flower spikes, which increase greatly in number during succeding years. The year after planting, it generally commences to flower in June and continues each season until severe frosts nip it. The foliage and blooms are exceedingly fine. The shrub is rather semi-herbaceous, by which we mean im some latitudes it will lie down to the ground and while perfectly hardy, we recommend covering the roots with manure, leaves or other suitable materials as winter approaches, as this will produce a heavy growth the following season. This shrub is very desirable as an individual specimen in the lawn and garden, or placed promiscuously in the shrubbery border. Fine plants, 25 cents. Strong. plants, 50 cents cach. 


\section{HARDY DECIDUOUS SHRUBS-Continued}

\section{Buxus}

(Ornamental Box.)

(Sempervirens)-Useful for edging and bordering walks, etc. A handsome shrub with deep green foliage. This is not as dwarf as the Sempervirens Nana, but we find it so much more vigorous and hardy that we advise planting this and trimming to height required. 20 cents each; $\$ 1.50$ per dozen, postpaid.

\section{Calycanthus Floridus}

\section{(Carolina Allspice or Sweet Scented Shrub.)}

A most desirable shrub. The wood is fragrant; flowers of a rare chocolate color, having a peculiar agreeable odor that is very penetrating. 'They plants, 25 cents; strong two-year-old plants, 50 ets.

\section{Deutzias}

Their fine habit, luxuriant foliage and profusion f bloom render them among the most beautiful of shrubs. They flower the latter part of June.

DEUTZLA CRENATA (Fl. Pl.)-Flowers double white, tinged with rose. 25 cents; two-year plants, 50 cents.

DEUTZIA GRACILIS-Dwarf habit. Covers itself with pure white bell-shaped flowers. 25 cents each; strong plants, 50 cents.

DEU'TZA GRACILIS ROSEA-Same as above, but pink flowers. 25 cents each; strong plants, 50 cts. DEUTZIA LEMIOINEI-Habit dwarf and free flowering; double white flowers. 25 cents; two-year plants, 50 cents.

DEUTZIA PRIDE OF ROCHESTER-Large double white flowers. 25 cents; two-year plants, 50 ets. FORSYTHIA (Golden Bells.) (Viridissima.) This splendid shrub lights up your garden with glinting masses of yeilow, very early in the spring before the leaves appear. The bark of the young twigs is bright green. 35 cents each.

FORSYTHIA (Fortunei.) Erect branches and handsome, broad, dark, green leaves. Fine for individual specimens. 35 cents eacl.

GOLDEN LLDER ("Sambusens Nigra.") (Varlegata Aurea.) Probably the most showy golden-leaved shrub. One of the finest shrubs for ornamental purposes. Foliage bright yellow with a profusion of berries. Gives a tone of contrast to any shrubbery planting. Two sizes, $\$ 5$ cents and 75 cents each. The KIng of All Shrubs

THE NEW HYDRANGEA ARBORESCENS GRANDIFLORA ALBA Hills of Snow

The Most Valuable Hardy Shrub Ever Introduced. Plant in the Fall.

This is the great new hardy shrub that has come to gladden our yards and gardens. We place it first and foremost of all shrubs. It makes a perfectly round, symmetrical bush that is covered from June to August with handsome, large, pure white flowers. Be sure and plant this new hardy shrub-it strong two-year plants, 50 cents.

\section{Hydrangea Paniculata Grandiflora}

A great favorite, and there is nothing finer or more showy, whether for planting in large masses in parks or for single plants on the smallest lawns. Blooms profusely from July until frost, in immense white panicles, tinted with pink and then with brown in the fully matured flower. The plant should be cut back each spring fully one-half of the past season's growth, as the flowers are much finer if the plant is treated in this manner. The flowers are much finer and larger if grown in a good, rich soil, but the plant. is so hardy and so easily grown that success is aimost certain in any kind of soil and in any situation. Young plants, 30 cents. Strong flowering plants, for inmedlate effect two sears old, 60 cents.

\section{Hibiscus Syriacus}

(Althea or Rose of Sharon)

Also known as the Hollyhock shrub, belongs to the Mallow family. These are the most beautiful shrubs we have in our collection. The flowers are of large size, very double and full of various brilliant and striking colors. They bloom freely during August and September, when scar shrub is in bloom. We offer.
ANEMONEFLORA - Largest of all Althea bloom: double wine-red.

BOULE DE FEU, or Ball of Fire-Double red.

COELESTE- Single sky-blue; extremely showy. JEANNE d'ARC-Double snow-white.

IONSTROSA-Semi-double white; red center.

PAEONIFLORUS-Double pink.

RUBUS-Single red; a striking variety.

VIOLET CLARE-Double violet; very popular.

SNOWDRIF'T (Totus Albus)-Single pure white.

Fine plants, 25 cents each, the nine for \$2.15. In two-sear plants, 50 cents each, the nine for $\$ 4.00$.

\section{Honeysuckle}

HONEYSUCKLE-Tartarian-(Lonieera Tartarian.) -The favorite old fashioned Bush Honeysuckie with slender upright branches. Pink flowers. 75 cents each.

HONEYSUCKLE-Tartarian-(Var. Alva.) A white flowering form of the above. 75 eents exch.

KERRIA JAPONICA FLORE PLENO (Corchorus,) Double orange-yellow flowers; borne abundantly in May. Flowers until October. Grows about two feet high and makes a neat, compact shrub that is very attractive. 30 cents each.

\section{Philadelphus or Syringa "Mock Orange"}

PHILADELPHUS-AURENS (Golden Syringa.) Valuable for contrastive grouping and the best golden-leaved shrub for edging on account of its dwarf nature. 75 cents each.

BOUQUET BLANC-Dwarf growth with long, slender branches densely covered from base to top with sweet-scented double flowers of creamywhite. In fact, the flowers are borne in such great profusion as to totally obscure the plant. Spicy fragrance. 25 cents.

CORONARIUS (Garland Syringa)-Pure white flowers, highly scented. 20 cents; two-year plants, 35 cents.

GRANDIFLoRUS (Large-Flowered Syringa)-Has very showy large white flowers, delicate fragrance. 20 cents.

MoNT BLANC-The branches of this beautiful variety are covered with white flowers that are deliciously fragrant. A grand species. 25 cents.

NEW PHILADELPHUS ("Virginal")-One of the most beautiful new ever-blooming varieties. A vigorous, tall grower with very large, doublecrested flowers, with round petals. Pure white sweetly scented; clusters of five to seven. Good strong plants, 75 cents each; three for $\$ 2.00$.

\section{Syringa or Lilac}

Well known beautiful shrubs, indispensable in every collection. It is doubtful if anything in the whole range of flowering shrubs surpasses these in grace and elegance, or in hardiness and usefulness. As decorative plants on the lawn or in the border they are without a peer. All of the Lilacs are deliciously fragrant. One-year plants of Lilacs, 12 to 18 inches high, 50e each; two-year plants, branched, 18 to 24 inches, T5e each: any nine Lilacs, in oneyear-old plants, for $\$ 3.75$; in two-sear-old plants, any nine for $\$ 6.00$.

ALPHONSE LAVALLE-Double dark blue, shading to violet. Extra large panicles, beautiful.

CHARLES $X$-A strong, rapid growing variety with large, shining leaves, trusses large, rather loose; reddish-purple.

JOSHKAE (Hungarlan Lilac)-Fine, distinct species, dark, shining leaves and purple fowers in June fter other Lilacs are done flowering. Extra fine.

MADA IIE CASIMIR PERIER-Very large, creamywhite: superb.

MADA IE LEMOINE - A superb double flowering white variety; can't be beat.

IARIE LEGRAVE-Large panicles of single white flowers. The finest white Lilac.

IICHAEL BUCHNER-Very large, erect panicles of

pale lilac; superb.
PERSICA, PERSIA LILAC-A delicate purple of rare beauty; very fragrant, rare.

PRESIDENT GREVY -A beautiful blue. Individual flowers very double and very large. The panicle is magnificent; one of the flnest Lilacs.

SOUVENIR DE LOUIS SPAETHE-Long panicles of large individual flowers, dark purplish-red; distinct. Superb.

VILLOSA-Color light pink, almost white; one of the latest.,to bloom; very showy.

vULGARIS (Common Lllac) -Bluish-purple fowers. A standard variety. Always good

VULGARIS ALBA-Common white Lilac; very large trusses of cream-colored flowers. Extra. 


\section{HARDY DECIDUOUS SHRUBS-Concluded}

\section{Spirea (Meadow Sweet)}

These are beautiful shrubs of the easiest culture. Their blooming extends over a period of three months. One-year, 25 cents each; strong two-yearold plants, 50 cents each.

ANTHONY WATERER-This beatiful gem makes a low, compact bush and is covered nearly the whole growing season with large umbels of deep crimson flowers which measure nearly a foot across. When scarcely three inches high it begins to bloom, and thereafter is seldom out of flower. As a pot plant or for growing in the open ground, nothing can equal it.

VAN HOUTTEI (Bridal Wreath)-Without doubt the rery finest of all shrubs. With us in May and early June the plant is completely covered with a mass of large white flowers presenting a beautiful appearance. Named the "Bridal Wreath" on account of its long graceful sprays of pure white.

\section{Snowball-Viburnum}

(Vibnrnnm opulns Sterilis)

(Gnelder Rose.) A well known favorite shrub of large size, with globular clusters of pure white flowers. The Snowball of our mothers' gardens. Blooms in May. One-year plants, 35 cents; twoyear plants, 60 cents.

\section{Plicatum, Japanese Snowball}

Handsome, plicated leaves with globular heads of pure white flowers, early in June. No shrub is prettier. 60 cents.

\section{Snowberry}

(Symphoricarpos Racemosus.) An excellent shrub for massing under trees and in shaded places, as well as in full sunlight. Very orriamental in the Fall; has a small white or pinkish flower, succeeded by showy white berries. 50 cents each.

\section{Weigelia-Diervilla}

They produce in June and July superb large trumpet-shaped flowers that almost hide the plant. They are very desirable for the border or for grouping, and as specimens on the lawn. One-sear plants, 35 cents; strong two-year plants, 60 cents. CANDIDA-A vigorous, erect grower; flowers pure white and produced in great profusion in June, and the plants continue to bloom through the summer even until autumn.

EVA RATHKE-A charming Weigelia flower, brilliant crimson. A beautiful distinct clear shade ROSEA-An elegant shrub with fine rose-colored

\section{HEDGE PLANTS}

We Here Name the Most Suitable Plants for Hedges Berberis-Barberry

(Thunbergii)-From Japan. A pretty species of dwarf habit. Small foliage changing to a beautiful coppery-red in autumn. A slower grower than the Privets, but needs no trimming and is a feast for the eye when full grown. One-year plants, 35 cents each; $\$ 4.00$ per dozen; $\$ 30.00$ per 100 , by express onls.

CALIFORNIA PRIVET OVALIFOLIUM-This makes when pruned a rery formal hedge, will grow almost anywhere, thriving where other plants refuse to grow. 18 to 24 inches, 20 cents each; $\$ 2.00$ per dozen; $\$ 15.00$ per hnndred.

Try our new Dwarf Philadelphus on page 37 , our Polyantha Roses on pages 8 and 9 , and Abelia Grandiflora on page 32 if you want something fine for hedge planting. The Abelia is only hardy south of Kentucky, but superb for Southern growing.

flowers; erect compact growth. Blossom in June

\section{OUR GENERAL CATALOGUE}

For the fall of 1922 will be ready in September. All purcliases from this catalogue, and all who have been customers within the past, will receive a copy FREE at the time it is issued, and without applying for it; others wishing it will please write for it. Should any of our patrons have friends requiring Bulbs, etc., we would be pleased to forward a copy of this catalogue on receipt of name and address. Customers changing their residence will kindly furnish us with their new address (also state their old address), so we can correct our lists and mail our catalogue properly.

\section{VELVET SOD LAWN GRASS}

Composed of a variety of fine, dwarf, close-growing grasses, which, on properly prepared, finely pulverized ground, will produce very quickly a neat velvety lawn and permanent sod. Has given universal satisfaction for the past twenty-five years. 40 cents per quart.

Do not forget to send for our book

"PEONIES FOR PLEASURE"

It tells all abont a great collection of these wonderful flowers. Write for it today.

Our Fall Catalog of Dutch Bulbs and everythlng for Fall Planting wlll be malled all our customers about September 1st. If you do not get a copy drop us a card.

\section{GARDEN IMPLEMENTS}

Rubber Plant Sprinkler-Indispensable for floral work and window gardening. Used to apply Thompson's Rose Nicotine. Invaluable when once tried. Used for dampening clothes or sprinkling in any way. \$1.50.

Trowel. Solid Steel-Absolutely the best Trowel in the world. One solid piece of steel, and will outwear several of the ordinary sort. 75e, prepald.

Excelalor Weeder-A very useful little tool for weeding seed beds, stirring the ground, etc. 25 cents, postpald. 


\section{Champion City Concentrated Plant Food}

The essence of plant life, fine for living plants; odorless. If you want to see your plants hump. try this Plant Food. We recommend it especially for plants grown in the house. So you test this food at small cost to you. We offer a trial size, mailed with directions how to use it, for 65 eents, postpaid. Will feed fifty plants one time and show you how it works. Larger package, making 160 pints, only $\$ 1.00$, postpaid.

\section{Thompson's Rose Nicotine}

THOMPSON'S ROSE NICOTINE is put up in sixty-cent (makes one and one-half gallons of spray) and eighty-five cent (makes six gallons) cans, and the FUMIGATOR is put up in fortycent packages. The Fumigator can be used to fumigate plants to kill insects. Can only be sent by express at above prices; we prepay expressage.
Melrosine

DEATH TO ROSE-BUGS

Many exasperated rose-lovers, seeing the best blooms of their pet roses destroy destroyed by this boiler-plate MELinosine he dies. This definite specific for the Rose-Bug is the outcome of many years of patient investigation by a professional gardener. Keeps indefinitely. It should be on hand in every garden as insurance against the ravages of the Rose-Bug. A small sum per plant expended for Melrosine will protect them.against this pest, and will also kill minor insects.

PRICE LIST OF MELROSINE

Per gallon, \$6.00; per one-half gallon, \$3.25; per quart, \$1.75; per pint, \$1.00; per trial ean, 50 cents. By express at purchaser's expense.

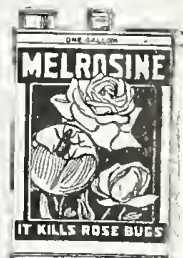

\section{SURPRISE COLLECTION ONLY \$1.00 \\ BY EXPRESS AT PURCHASER'S EXPENSE}

We usually have at the end of the selling season a number of choice plants that we have grown a surplus of. To those who will send us a dollar, we will, after June 1, 1922, send a fine lot of plants that will be a surprise to you. If your order goes by express, we can send many more plants than if it goes by mail. So send us a dollar, and after June 1, we will send you the Surprise Collection of plants. The selections to be strictly our own. We sold several thousand of the Surprise Collection last June, and everyone was pleased with them.

\section{CHOICE FLOWER SEEDS}

\section{Any Six Packets Priced at 5 Cents Sent for 25 Cents}

Price per pkt.

Abrus Precartorius-West Indian Weather Plant....... 5c Achillea, The Pearl-Hardy; pure white double flowers.... 100 Ageratum-Imperial dark blue................. 5c Ageratum-Imperial pure white................. $5 c$ Adlumia Cirrhosa-Allegheny Vine, or Mountain Fringe.. 5c Agathea Celestis (Blue Daisy)-Hardy perennial........ I0c Alyssum, Sweet-The old fuvorite; very fragrant...... 5c Alyssum, Little Gem-New dwarf variety............ 50 Anchusa Capensis-Cape Forget-Me-Not............. 50 Antigonon Leptopus, or Mountain Beauty........... 5c Antirrhinum, Dwarf Mixed-Dwarf Snapdragons; all colors 50 Antirrhinum, Dwarf Mixed_Dwarf Snapdragon; all colors. 5c Aquilegia, Double Mixed-All colors of Columbine...... 50 Aquilegia, Single Mixed-All colors of Columbine...... 5c Aristolochia Sipho-.Dutchman's Pipe," fine.......... I0c Arabis Alpina-Hardy white perennial............ 50 Aster, Imperial Dwarf Mixturo-All colors............ 10 Aster, Imperial Tall Mixture-All colors............. I0 c Aster, Giant Branching-Pure white.............. $10 \mathrm{c}$ Aster, Giant Branching-Clear pink............... 10c Aster, Giant Branching-Darkest crimson............ 10c Aster, Giant Branching-Light blue.............. 10 c Aster, Giant Branching-Royal purple.............. 10c Aster, Giant Branching-Delicate lavender............ 10c Aster, Giant Peony-Flowered-All colors, mixed........ 100 Aster, Giant Comet-All colors.................. I0 Aster, Queen of the Market-Earliest of all; flve colors... 100 Aster, Giant King-Needled type ; mixed.............. 10 c Aster, Giant-0strich feathered type : mixed.......... I0c Aster, ChIna or Common Mixed-In twenty colors....... 5c Aster, Cocardeau or Crown Asters-All colors; mixed...... I0c Arctotis Grandis-African Lilac Daisy............... 5 Anemone (Wind Flower)-Hardy mixed colors.............. 5e Ampelopsis Veitchil-(Boston Ivy.) A hardy climber..... 5
Price per adt Balsam Pear-fruit used medicinally................ 10 Balsam, Camellia-Flowered-All colors; mixed......... $5 \mathrm{c}$ Balsam, or Touch-Me-Nots-Lady Slippers; all colors.... 5c Bird of Paradise-Orange-red; flowers in clusters........ 5 Calendula, or Pot Marigold, Mixed-All colors..........., 5 Coreopsis Grandiflora Lanceolata-Hardy yellow........ $5 \mathrm{c}$ Campanula (Canterbury Bell) -Double mixed........... 5 Campanula (Canterbury Bell) - Single mixed............. 5c Campanula, Cup and Saucer-Mixed............... 5 Candytuft, Snow Queen-Pure white............... $5 c$ Candytuft, Giant Hyacinth-Flowered-Mixed........... 5c Candytuft, New Dwarf Hybrid-Mixed colors.............. 5 Candytuft, Odorata, or Sweet-scented-old favorite........ 5 Cannas-The dwarf French ever-bloomers, mixed........... I0e Carnations, King of the Scarlets-Glowing scarlet............ 25 c Carnations, Giant Marguerite-Mixed eclors............... 25c Carnations, Double Mixed-All colors............... 20c Centaurea Imperialis-Mixed colors................ 5 Centaurea Cyanus-Ragged Sailor, Cornflower, Blue Bottie, Bachelor's Button, mixed colors. ........................ $5 \mathrm{c}$ Centaurea Gymnocarpa-Dusty Miller.................... $5 c$ Celosia Cristata, or Coxcomb-Tall mixod:.............. 3t Celosia Cristata, or Coxcomb-Dwarf mixed ............. Je Centrosema Grandiflora (Butterfly Pea)-Hardy vine..... $10 \mathrm{c}$ Chrysanthemum Annual-Mixed colors.................... $5 c$ Chrysanthemum Annual, Morning Star-Yellow......... Chrysanthemum Annual, Coronarium-Double white...... $5 c$ Cobea Scandens-Bell-shaped flowers; climbing............. $5 \mathrm{e}$ Cosmos-(Early Hybrids.) Mixed colors................ 5e Cosmos, Giant Mixed-Alt colors..................... 5 Cosmos, White Lady Lenox....................... 10e Cosmos, Pink Lady Lenox...................... 10e 


\section{CHOICE FLOWER SEEDS-Concluded}

\section{Any Six Packets Priced at 5 Cents Sent for 25 Cents}

Price per pkt.

Cypress Vine-Mixed seed; fine climber............. 5c

Cucumber, Wild-A rampant climber; fine for shade..... 5

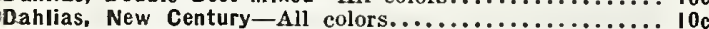

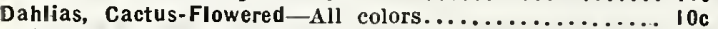

Datura, or Horn of Plenty-(Or Angel's Trumpet.) Mised. 5c

Delphinium (Larkspur)-Annual mixed................

Delphinium (Larkspur) - Perennial mixed...............

Dianthus, or Hardy Japanese Pink - All colors........... 5 c

Dictamnus Fraxinella (Gas Plant) - White flowers........ $5 c$

Dolichos-Hyacinth Bean, or Scarlet Runner..........

Digitalis (Foxglove) - All colors, mixed..............

Double Daisy (Bellis Perennis)-Hardy; all colors....... I0

Daisy. Shasta - New, fine, large pure white............. I5c

Eschscholtzia (California Poppy) - All colors, mixed...... I0c

Euphorbia Variegata, or Snow-on-the-Mountain.

Forget-Me-Not, or Myosotis-Mixed colors....

Gaillardia, or Blanket Flower-Mixed colors...

Gourds, Ornamental-All kinds, mixed.

Gypsophila (Angel's Breath)-Hardj; mixed colors...

Godetia, or Satin Flower-Choicest varieties.

Helianthus, or Sunflower-Mammoth Russian..

Helianthus, or Sunflower-Miniature. .

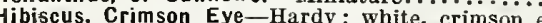

Hibiscus Hybrida-Hardy; all colors, mixed.

Hollyhocks, Mammoth Allegheny-Mized colors.

Hollyhocks-Rainbow mixture of prize Hollyhocks.

Inomea, Heavenly Blue-The Blue Moonflower.

I pomea, Grandiflora Alba-The White Moonflower.

Kudzu Vine (Jack and the Bean Stalk)-Hardy vine.

Lathyrus, or Everlasting Pea-Hardy, very sweet, mixed... I0 Lavender-The old-fashioned Sweet Lavender.

Lantana, or Shrubby Verbena-All colors.

Lemon Verbena-Very fragrant; lemon-scented foliage....

Marigold-Dwarf French mixed; all the good varieties.

Marigold, Eldorado, or Dahlia-Flowered-Best of all.

Mignonette, Giant Machet-Giant, fragrant flowers.

Mignonette, Odorata, or Sweet Mignonette-All colors $\mathrm{mix}$. Morning Glories, (Convolvulus Major)-Common Mornin Glory Gix,

Morning Ǵlories, Japanese-Ail colors, mixed.

Morning Glories, Brazilian-Very remarkable; mixed......

Mirabidis Jalapa, Marvel of Peru, or Four O'Clock... .

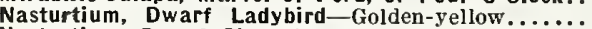

Nasturtium. Dwarf Chameleon-Crimson and bronze.

Nasturtium, Dwarf, Empress of India-Crimson-scarlet.

Nasturtium, Dwarf, Spotted King-Orange, spotted ma roon

Nasturtium. Dwarf, Tom Thumb-All colors, mixed..... 5c

Per ounce, 20 cents.

Nasturtium, Tall, Giant of Battles-Sulphur, spotted red. . Nasturtium, Tall, Lucifer-Richest dark scarlet. Nasturtium, Tall, Sunrise-Magnificent pure yello Nasturtium, Tall, Mme. Gunther's Hybrids - All colors.... Per ounce, 20 cents.

Nasturtium, Majus Tall-All colors, mixed. (Oz. 20c)

Nasturtium, Canary Bird Flower-Charming vine...... 5c

Nigelia (Love-in-a-Mist, or Devil in a Bush) ..........

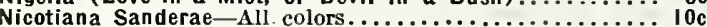

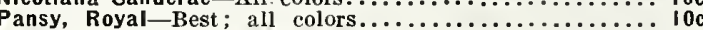

Pansy, Peacock-Fancy flowers mixed................ loc

Pansy, Victoria Red-Beautiful deep red.............. I oc

Pansy, Giant Trimardeau-A fancy strain............. I0c

Pansy, sweet-scented-All colors, mixed.................

Pansy, G. \& R. International Mixture-Grand........... I0c

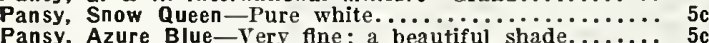

Pansy, Bronze Color-A new and striking color......... 5c

Pansy, Cliveden Purvle-A rich dark purple.......... 5c

Pansy, Dark Blue-Rich and lasting................ $5 \mathrm{c}$

Pansy, Fawn Color-A beautiful shade of fawn.

Pansy, King of the Blacks-Almost coal black.

Pansy, Yellow Gem-Generally true to color.

Pansy, Brilliant-Bright coppery color, not strictly red.... 5c

Pansy, Striped and Mottled-Fine and exceedingly beautiful 50

Pansy, Violet Queen-White border, somewhat resembling

ansy, White Wings-White with black eye.

Pansy, Yellow Margined-A beautiful color, with margin or

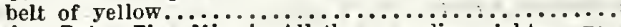

Pansies, Extra Fine Mixed-All the preceding eighteen va:

rieties, mlxed.......................

Petunia Grandiflora - The largest and best of a $\ldots \ldots \ldots 20$

Petunia, Large-Flowered, Mixed.................. 5c

Petunia, Howard Star-Velvety crimson, with star........ I0 c
Price per pkt.

Phlox Grandiflera-Mixed large-flowering; all colors..... 5c Phlox Coccinea-Lovely scarlet Phlox............... 5c Phlox Cuspidata, or Star of Quedlinburg-odd......... $5 c$ Phlox Golden Harvest-Richest yellow............... 5 c Phlox Snowdrift-Pure immaculate white........... Phlox Pink Beauty-Large clear pink................. $5 \mathrm{c}$

Phlox Nana Compacta-Dwarf; all colors............ 5c Phlox Drummondi-Finest mixed................... Popy, the Shirley-New ; very popular............. 5 c Poppy, Snowdrift-Double; pure white............. $5 c$ Poppy, Golden Gate-Lorely rariegated colors........... 5c Poppy, Firedragon-Deep scarlet................ Poppy, Nudicaule, or Iceland Poppy-Yellow.......... 5c Poppy, Extra Fine Mixed-All colors................ 50 Poppy, Oriental-Hardy perennials; mammoth flowers.... I0 c Portulaca (Rose Moss) - Double mised; very bright....... loc Primula, or Chinese Primrose-Winter bloomer. Primula obconica Grandiflora-Winter bloomer; mixed.... I0c Primula Forbesi (Baby Primrose) - Winter bloomer....... I5c Primula Veris Grandiflora (Cowslip)-Mixed colors....... I0c Primula Vulgaris-The true yellow Prin rose............. Pink Picotee, or Hardy Pink-All colors............... I5c Ricinum (Castor Oil Plant)-Mixed..................... Rubbeckia Bicolor Superba-Hardy perennial; elegant.... 5c Salpiglossis-All colors, mixed................ $5 c$

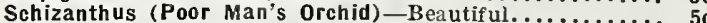
Salvia Splendens (Scarlet Sage)-Deep scariet............. I0 Scabiosa, or Mourning Bride-All colors, mixed.......... 5c Stokesia Cyanea (Cornflower Aster)-Hardy; elegant..... I5c Smilax - An elegant house vine.................. 5 Stock, or Gillyflower-Dwarf German : all colors.......... I0c Sweet William-Double giant-flowered; mixed........... 5c Spencer Sweet Pea-Barbara salmon................ I5c Spencer Sweet Pea, Blue Jacket-A fine deep nary blue.. I5c Spencer Sweet Pea, Countess Spencer-Soft rose-pink.... I5c Spencer Sweet Pea, Florence Nightingale-Larender...... I5c Spencer Sweet Pea, King Edward-Scarlet.............. I5c Spencer Sweet Pea, Mrs. Sankey-Pure white............. I5c Spencer Sweet Pea, Primrose Spencer-A creamy-yellow... I5c Sweet Pea, America-White Striped, orange-scarlet..... 5c Sweet Pea, Apple Blossom-Bright rosy-pink and red.... 5c Sweet Pea, Aurora-White flaked and striped salmon..... 5c Sweet Pea, Black Knight-Deep maroon............. 5c Sweet Pea, Blanche Ferry-Extra early pink and white... 5 Sweet Pea, Captain of the Blues-Best blue to date..... 5c Sweet Pea, Dorothy Eckford-Grandest pure white....... 5c Sweet Pea, Dainty - White, with pink edges.......... 5 c Sweet Pea, Frank Dolby-Largest pale blue............ 5 c Sweet Pea, Gladys Unwin-Pale rosy pink.............. 5 c Sweet Pea, Henry Eckford-Orange color.............. 5 c Sweet Pea, King Edward VII-Bright red.............. 5c Sweet Pea, Lady GriseI Hamilton-Best giant pink......... 5c Sweet Pea, Lord Nelson-Deeper and richer than nary blue 5c Sweet Pea, Lovely-A beautiful shell-pink............ 5c Swect Pea, Miss Willmott-orange-pink, shaded rose..... 5c Sweet Pea, Mrs. Walter Wright-Mauve color.......... 5c Sweet Pea, Nora Unwin-Giant white................ 5c Sweet Pea, Prince of Wales-Brightest rose........... Sweet Pea, Prince Olaf-White marbled, clear blue........ 5 c Sweet Pea, Salopian-The best dark red............ 5c Sweet Pea, Best Mixture-Per ounce, $15 \mathrm{c} \ldots \ldots \ldots \ldots \ldots \ldots .5 \mathrm{f}$ Sweet Pea, Dwarf Cupid-Mixed................. 10c Thunbergia (Black-Eycd Susan) .................. 5c

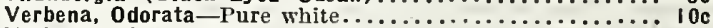
Verbena, Fine Mixed-All colors....................... Verbena, New Mammoth-Flowering-All colors............ I0c Verbena. Mammoth Pink.................... 10c Verbena. Mammoth Scarlet................ I0c Vinca, Alba Madagascar (Periwinkle) - White............ 5c Vinca, Rosea Madagascar (Periwinkle)-Rose.......... 5c Wall Flower-Double mixed; all colors............... 5c Wild Flower Garden-Everything for a wild garden...... 5c Zinnia, Crested and Curled-All colors ............. 5c Zinnia Elegans-Choicest double; all colors........... 5c Zinnia Plenissima - Double pink. .............. I0c Zinnia Plenissima-Double red..................... 10c Zinnia Plenissima-Double rose..................... I0c Zinnia Plenissima-Double white................... 10c Zinnia Plenissima-Double 5ellow................. I0c Zinnia Plenissima-Double; extra large............... 10c Zinnia, Tom Thumb-Dwarf, all colors................5c Zinnia, Lilliput Dwarf-Red Riding Hood............... I0c New Zinnia, Picotee Type-Edge of petals marked with a distinct color to body of flower ; mixed colors.........

New Zinnia, Dahlia-Flowered Type-Very fine; mlxed col $20 \mathrm{c}$ 


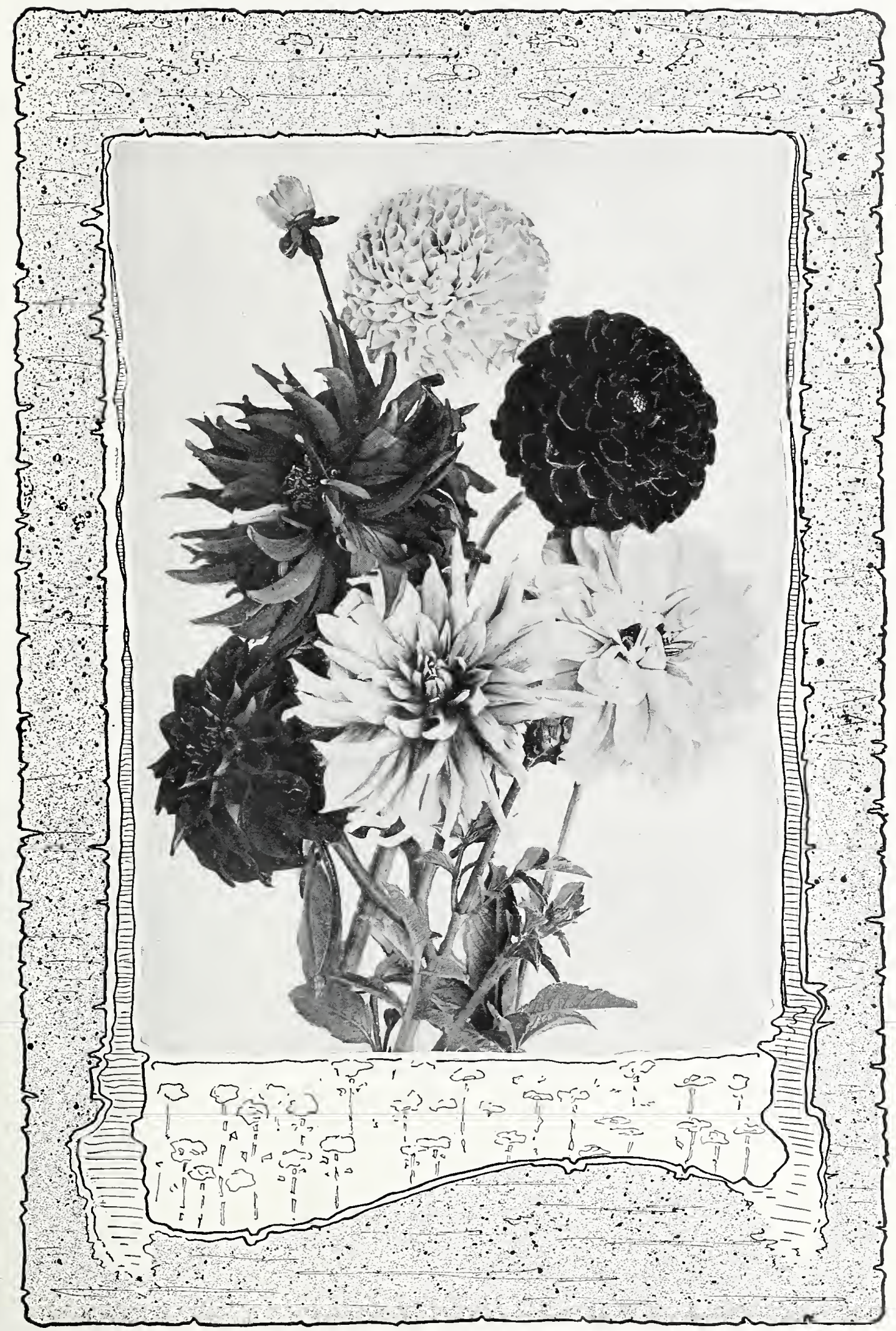




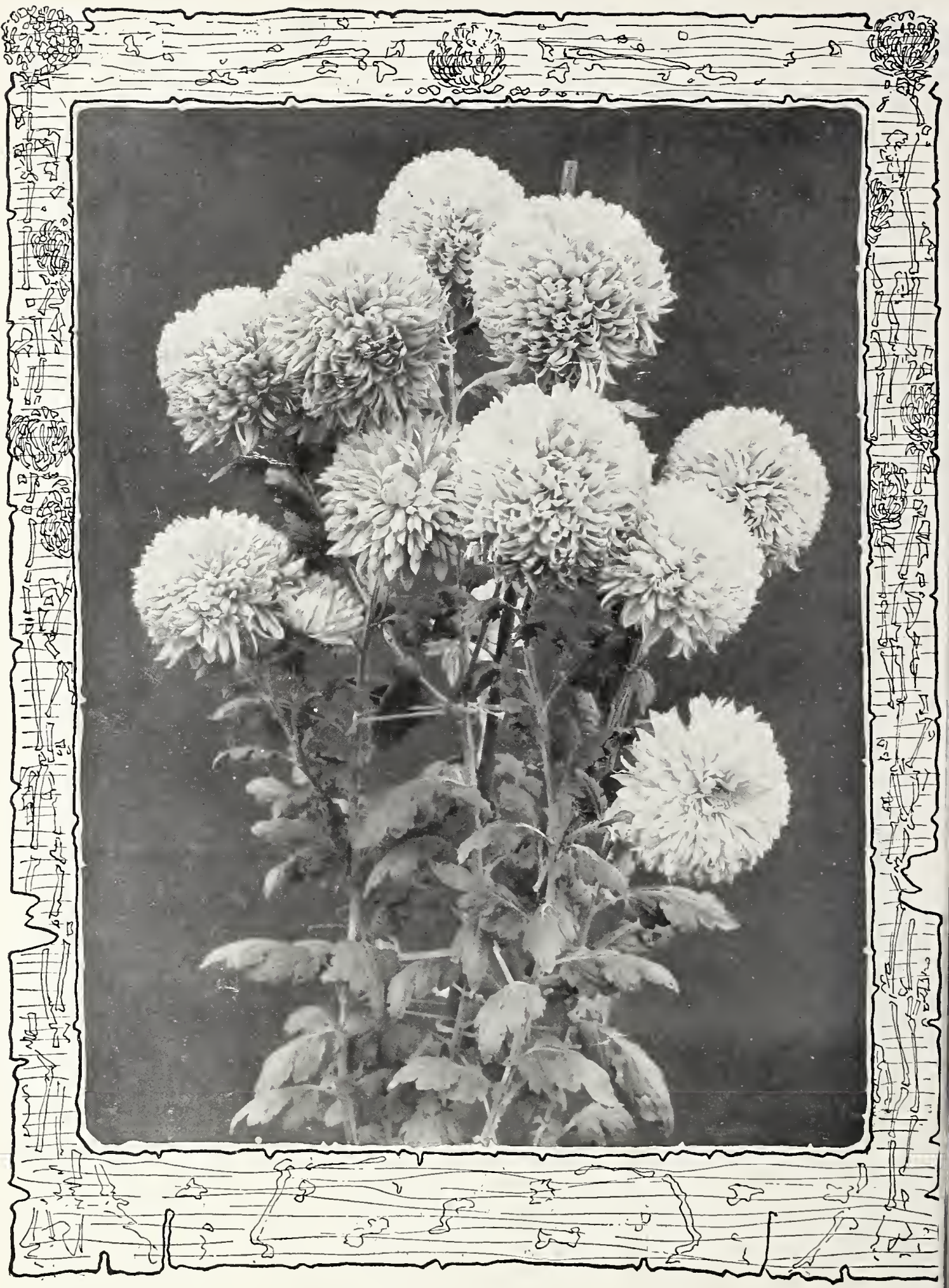

